IZA DP No. 6407

Up or Out:

Research Incentives and Career Prospects of Postdocs in Germany

Bernd Fitzenberger

Ute Leuschner

March 2012 


\title{
Up or Out: Research Incentives and Career Prospects of Postdocs in Germany
}

\author{
Bernd Fitzenberger \\ Albert-Ludwigs-University Freiburg, \\ IFS, ZEW and IZA \\ Ute Leuschner \\ Albert-Ludwigs-University Freiburg
}

Discussion Paper No. 6407

March 2012

\author{
IZA \\ P.O. Box 7240 \\ 53072 Bonn \\ Germany \\ Phone: +49-228-3894-0 \\ Fax: +49-228-3894-180 \\ E-mail: iza@iza.org
}

\begin{abstract}
Any opinions expressed here are those of the author(s) and not those of IZA. Research published in this series may include views on policy, but the institute itself takes no institutional policy positions.

The Institute for the Study of Labor (IZA) in Bonn is a local and virtual international research center and a place of communication between science, politics and business. IZA is an independent nonprofit organization supported by Deutsche Post Foundation. The center is associated with the University of Bonn and offers a stimulating research environment through its international network, workshops and conferences, data service, project support, research visits and doctoral program. IZA engages in (i) original and internationally competitive research in all fields of labor economics, (ii) development of policy concepts, and (iii) dissemination of research results and concepts to the interested public.
\end{abstract}

IZA Discussion Papers often represent preliminary work and are circulated to encourage discussion. Citation of such a paper should account for its provisional character. A revised version may be available directly from the author. 


\section{ABSTRACT}

\section{Up or Out: \\ Research Incentives and Career Prospects of Postdocs in Germany ${ }^{*}$}

Academic careers in Germany have been under debate for a while. We conduct a survey among postdocs in Germany, to analyze the perceptions and attitudes of postdocs regarding their research incentives, their working conditions, and their career prospects. We conceptualize the career prospects of a postdoc in a life-cycle perspective of transitions from academic training to academic or non-academic jobs. Only about half of the postdocs sees strong incentives for academic research, but there is quite a strong confidence to succeed in an academic career. Furthermore, postdocs who attended a PhD program show better career prospects and higher research incentives compared to others. Academic career prospects and motivation are strongest for assistant professors. Apart from this small group, however, postdocs report only a small impact of the university reforms of the last decade. Female postdocs show significantly higher research incentives but otherwise we find little gender differences. Finally, good prospects in non-academic jobs are not associated with a reduction in the motivation for research.

JEL Classification: A11, A29, 121, I23, J24, J49

Keywords: postdocs, academic career prospects, research incentives, university reforms

Corresponding author:

Bernd Fitzenberger

Department of Economics

Albert-Ludwigs-University Freiburg

79085 Freiburg

Germany

E-mail: bernd.fitzenberger@vwl.uni-freiburg.de

\footnotetext{
* We thank the newspaper Handelsblatt for financial support. In January 2009, the Handelsblatt published an article written by Doris Heß, which was based on the same data set as this work (Heß, 2009). We thank all participants of our online-survey for providing the data used in this study, and we thank Alexandra Spitz-Oener for helpful comments. We are grateful to Maximilian Blömer for excellent assistance in setting up the online survey. The responsibility for all errors is, of course, ours.
} 


\section{Contents}

1 Introduction 1

2 Background and Theoretical Framework 3

2.1 Background and Review of the Literature . . . . . . . . . . . . . . . . 3

2.2 Life-cycle Phase Framework . . . . . . . . . . . . . . . . . . . . 6

2.3 Hypotheses . . . . . . . . . . . . . . . . . . . . . . . 9 9

3 Data and Descriptives 12

3.1 Description of Survey . . . . . . . . . . . . . . . . . . 12

3.2 Descriptive Statistics . . . . . . . . . . . . . . . . . . . . . . . . . . . . 12

4 Cluster Analysis of Researcher Types 14

5 Econometric Analysis $\quad 15$

5.1 Research Incentives . . . . . . . . . . . . . . . . . . . . . . . 16

5.2 Career Prospects . . . . . . . . . . . . . . . . . . . . . . . 18

$5.3 \mathrm{PhD}$ Background . . . . . . . . . . . . . . . . . . . . 20

5.4 Gender, Age, Children . . . . . . . . . . . . . . . . . 21

5.5 Different Academic Fields . . . . . . . . . . . . . . . . . . . . . 22

6 Conclusions 23

$\begin{array}{ll}\text { References } & 24\end{array}$

$\begin{array}{lr}\text { Appendix } & 27\end{array}$ 


\section{Introduction}

The academic career path in Germany is characterized by the availability of only few tenured professorships, high rates of dropout from an academic career both right after completion of a $\mathrm{PhD}$ and at further stages as a postdoc, disproportionately high rates of dropouts by females, and a high average age of appointment to a full professorship (BMBF, 2008). There is concern that the conditions for an academic career make academic research positions in Germany less attractive and less competitive in comparison with both jobs outside of academia and research positions abroad (Bulmahn, 2001; Enders and Bornmann, 2002b; Burkhardt, 2011). This may hold in particular for postdoc positions, a stage in which young academics should be most productive in research. Postdocs typically still work under the supervision of a tenured professor, lack independence in comparison to assistant professors in other countries, and have fairly insecure career prospects compared to a well-defined tenure-track system (Bareither, 2008; Buchholz et al., 2009; Bulmahn, 2001; Janson et al., 2007). Furthermore, key decisions relating to family formation are made during the postdoc phase, and there is concern that a disproportionate number of promising female PhD's do not continue an academic career because of the insecurity and the difficulties to combine an academic career with having a family (BMBF, 2008; Jung, 2011). However, little is known about the sentiments of postdocs on a statistically representative basis. For this reason, we conduct a survey among postdocs in the fields of business economics, economics, sociology, and social sciences.

The public debate reports negative sentiments and frustration among postdocs in Germany, and it is often argued that many of the most promising young researchers leave Germany or do not come back to Germany because of better working conditions in countries like the United States (Bulmahn, 2001; Janson et al., 2007; Prußky, 2008). Recognizing some of these concerns, the German government implemented various reforms of the university system during the 2000's (Bulmahn, 2001). Regarding the postdoc phase, the goals of the reforms were to strengthen the independence of postdocs and their incentives for excellent research as well as to lower the age at which a successful researcher can make the transition to a tenured professorship. Assistant professorships ('Juniorprofessur') were introduced with the right to supervise PhD students. Although, this was a goal of the reforms, most assistant professorships do not involve tenure-track. Over the last decade, there has been a decline of postdocs completing a Habilitation (Handelsblatt, 2009; StBA, 2011). However, assistant professorships have by no means replaced the Habilitation.

Based on a survey in the fields of business economics, economics, sociology, and social 
sciences, our paper contributes to the understanding of the situation and the sentiments of postdocs in Germany. In a situation with a high dropout rate from an academic career, we emphasize the interplay between academic and non-academic career prospects. We first develop a number of hypotheses regarding career transitions after the completion of a $\mathrm{PhD}$ based on a theoretical framework. Drawing on our survey data, we then analyze the research incentives, the academic background, and the career prospects of postdocs. We also investigate their perception of the university reforms of the last decade. The comparison across different fields allows us to investigate the impact of different nonacademic career opportunities (Chlosta et al., 2010).

Our results show quite a mixed picture. We identify three important types of postdocs: motivated optimists, confident academics, and frustrated pessimists. Only about half of the postdocs sees strong incentives for academic research, but there is quite a strong confidence to succeed in an academic career. There is evidence that research incentives increase due to stronger international competition. Employment insecurity results in a more pessimistic assessment of an academic career. The strongest research incentives and the best career prospects were found for assistant professors ('Juniorprofessoren/innen'). Apart from this small group, the postdocs see only a small influence of the university reforms of the last decade on incentives and prospects for researchers. There is no evidence for declining research incentives due to better non-academic career prospects. Female postdocs show significantly higher research incentives but otherwise we find little gender differences. Irrespective of gender, the presence of children is associated with significantly worse perceived career prospects.

The remainder of this paper is organized as follows. Section 2 describes the background, introduces a theoretical framework to analyze the career decision of a postdoc, and develops a number of hypotheses. Section 3 describes our survey among postdocs. Section 4 reports the result of a cluster analysis and section 5 reports our econometric analysis. Section 6 concludes. The appendix includes additional derivations, information about the data, and detailed empirical results. We have also prepared an additional appendix with further detailed information about the data and empirical results which we refer to in the paper. 


\section{Background and Theoretical Framework}

\subsection{Background and Review of the Literature}

Traditionally, a postdoc at a German university completes a second postgraduate degree after the PhD, the so-called 'Habilitation' (postdoctoral lecture qualification) to become eligible for a tenured professorship. After completion of the Habilitation, the postdoc can apply for a tenured professorship, typically at other universities. During the Habilitation phase, the postdoc typically works as an assistant at the chair of a tenured professor. Over the last decade, there has been a decline of postdocs completing a Habilitation (Handelsblatt, 2009; StBA, 2011). The university reforms of the last decade introduced assistant professorships ('Juniorprofessur'). Such positions last no more than six years and are intended to provide a more independent alternative to the Habilitation. Bulmahn (2001) calls for the introduction of assistant professorships with a tenure-track option to make an academic career more attractive (see also Buchholz et al. (2009) and Jung (2011)), but the majority of assistant professorships today do not involve tenure-track.

As part of the university reforms, a new salary system for professors was introduced (Bulmahn, 2001; Zoske, 2008): since 2005, professors can only be appointed for a professorship in the new 'W-salary system', which replaces the old, fairly rigid 'C-salary system'. The 'W-salary system' implements a more flexible and performance-oriented pay system with lower base salaries. The base salary of assistant professors was lowered compared to the base salary of former assistants at a chair who had received a C1-salary during the Habilitation phase.

In addition, the debate about the best way to organize the PhD phase in Germany has been just as intense as the debate about postdocs (BMBF, 2008). There are strong calls for the introduction of structured U.S. style $\mathrm{PhD}$ programs to replace the traditional way of completing a PhD in Germany. It is argued that a traditional PhD does not allow $\mathrm{PhD}$ students to acquire a sufficiently broad range of research perspectives and that $\mathrm{PhD}$ students have insufficient independence when they are supervised by just one tenured professor. This discussion prompted the German government in the last decade to award the assistant professors with the right to supervise $\mathrm{PhD}$ students.

Even though there are strong differences in the academic system between Germany and, say, the U.S. (Buchholz et al., 2009), the academic system in the U.S. (and to some extent the UK) serves as a benchmark in the discussion about university reforms in Germany (Janson et al., 2007; Buchholz et al., 2009; Bulmahn, 2001). Gillmann (2006) notes that the career prospects for postdocs in the United States are still better than in Germany. Important reasons are the tenure-track-system, higher pay, and better promotion 
prospects. We first review two studies for the U.S. (one of which involves a cross-country comparison) and then focus on Germany. Regarding the decision about whether to continue an academic career or not, the discussion distinguishes between push factors, such as good or bad working conditions as a postdoc and academic career prospects, and pull factors, such as non-academic career prospects.

Fox and Stephan (2001) analyze the career-preferences and the prospects of young researchers. The study does not include the fields economics, business economics, sociology, and social sciences. The authors conduct a mail survey among $3.800 \mathrm{PhD}$ candidates and find a rather pessimistic assessment of career prospects. The study argues that this is related to the large increase in the number of $\mathrm{PhD}$ candidates, which reduces their respective academic career prospects. In a follow-up study, Stephan (2008) analyzes the academic job prospects for PhD's and their impact on research productivity in the U.S., Italy, and Germany for the fields of physics, life sciences, mathematics, and engineering. The study concludes that academic career prospects for PhD's have deteriorated in all three countries, which might lead to a fall in the number of PhD candidates. For Germany, the study points to a decreasing number of postdocs completing a habilitation and to the reduction in the number of professorships, both reflecting the poor academic job prospects. In addition, the study also finds that in the EU, the number of scientists with a $\mathrm{PhD}$ hired by industry has been falling as well. As a result, Stephan sees a risk of falling scientific productivity because an academic career has become less attractive. She also argues that good non-academic career prospects causes a shift away from basic to more applied research. Somewhat in contrast to the hypothesis that non-academic career prospects after completion of a PhD have deteriorated, the recent study by Lindley and Machin (2011) shows that the wage return to postgraduate education beyond a college degree (including the completion of a PhD) has been rising in the U.S. and the UK. All this suggests that future non-academic career prospects may play an important role for both PhD's and postdocs.

The weak career prospects for postdocs in Germany are reflected by the high average age when completing a habilitation, at which non-academic career prospects may have deteriorated compared to the options right after completion of the $\mathrm{PhD}$, and the comparatively small number of professorships (BMBF, 2008; Fitzenberger, 2008; Schulze, 2008; Gülker, 2011). With increasing age, postdocs may become more present-oriented and thus less willing to invest into a risky academic career (Chlosta et al., 2010). Bareither (2008) emphasizes that the decision to pursue an academic career in Germany involves a big personal risk. As part of the university reforms a decade ago, the introduction of the junior professorship and the change of the salary-system should have improved the 
independence and the working conditions of postdocs. However, because of the lack of tenure-track option for most assistant professors and because of lower salaries, the effect of the reforms on the research effort among postdocs may be ambiguous (Fitzenberger, 2008). In fact, Leffers (2007) argues that assistant professors have no better academic career prospects than other postdocs.

Female PhDs in Germany are less likely to continue an academic career compared to male PhDs (BMBF, 2008; Jung, 2011). This is often attributed to the difficulties in reconciling an academic career with having a family. Correspondingly, female PhDs may be more risk averse in their career decisions (Dohmen and Falk, 2011; Jung, 2011). Being in a partnership and/or having children may increase the present-orientation, thus reducing the incentives to invest in a risky academic career. Incidently, for the U.S., Fox and Stephan (2001) find no significant gender effects with regard to how insecure career prospects affect academic decisions. This suggests that cross-country differences in academic systems and possibilities to reconcile an academic career with having a family may be important.

There exists only a scarce literature which deals explicitly with career prospects of academics in Germany. Enders and Bornmann (2002b) find that having a position at a university when completing the $\mathrm{PhD}$ is important for future academic career prospects. In addition, the integration into the scientific community, reflected by publications in journals or participation in conferences, is associated with better future academic career prospects. Chlosta et al. (2010) analyze the decision for an academic career in business economics, a field with presumably very good non-academic career prospects. The study finds that the number of publications, work satisfaction, as well as perceived career chances have a significant positive effect on the decision to continue an academic career. A higher individual rate of time preference (proxied by the presence of children) has a negative effect. In contrast, they found no significant effect of the expected earnings in a nonacademic job within the same sub-discipline of business economics. This result may be due to the small number of cases and they nevertheless emphasize the importance of monetary factors. Furthermore, because of the possibility to switch subfields within business economics, this result does not necessarily imply that the stark differences in non-academic career prospects across fields have no impact on the decision to continue an academic career.

A number of studies analyze research productivity, mobility, and qualifications over the life cycle (Heining et al., 2008, 2007; Rauber and Ursprung, 2008a,b). Rauber and Ursprung (2008a,b) find that research output depends strongly upon the cohort of the researchers. Schulze et al. (2008) analyze the determinants of tenure decisions for those 
who successfully completed a habilitation in economics or business economics. The study finds that publications are important determinants for receiving tenure, a finding also confirmed by Heining et al. (2007), and that publications are substantially more important in economics than in business economics.

Analyzing the international mobility of German PhDs, Enders and Bornmann (2002a) find no evidence for an increasing outmigration to foreign universities. However, about $25 \%$ of all economists go abroad after completion of their $\mathrm{PhD}$, most of them to take a job in the private sector. While the number of postdocs going abroad is fairly small, these are often particularly excellent researchers. Thus, there seems to be a qualitative rather than a quantitative problem of outmigration.

Similar to our study, Jaksztat and Briedis (2009) conduct a survey on the individual perception and job satisfaction among postdocs and $\mathrm{PhD}$ candidates in nearly all fields in Germany. The study finds a negative assessment of the Bologna-reforms. Nevertheless, $40 \%$ of the survey respondents want to pursue an academic career. In a subsequent study, Jaksztat et al. (2010) conduct a large survey on work conditions, career plans, and competencies. They compare universities with research institutions outside of universities. The results show that young researcher have huge concerns regarding job insecurity (mainly because of fixed-term contracts) and they find it very difficult to plan a career.

\section{$2.2 \quad$ Life-cycle Phase Framework}

An academic career evolves through various stages (BMBF, 2008). Figure 1 depicts possible career transitions after the completion of a $\mathrm{PhD}$. Obtaining a $\mathrm{PhD}$ is mainly a training phase when the $\mathrm{PhD}$ candidate learns how to successfully develop and implement a major research project which results in a significant contribution to the literature. After completing a PhD, a person may continue his/her academic career as a postdoc at a research institution (e.g. universities) or switch to a non-academic career. The postdoc position also includes assistant professorships (W1 positions, 'Juniorprofessur'). A postdoc will either eventually make the transition to a tenured professorship (W2/W3) along the academic career or exit to a non-academic career. ${ }^{1}$ In the following, we simply refer to a tenured professorship (W2/W3) as professorship and explicitly say so when referring to a junior professorship.

\footnotetext{
${ }^{1}$ Figure 1 excludes the posssibility of tenured postdoc research positions, e.g. as a tenured lecturer ('Akademischer Rat/Rätin'). Nowadays, such positions are rare at German universities. A sizeable number of tenured positions as researcher do exist at research institutes. Typically, these positions involve contract research or consulting work, which we subsume as an exit to a non-academic career as opposed to obtaining a professorship. Our analysis also abstracts from the fact that W2/W3 professorship may at first involve temporary appointments and in a number of cases may not lead to tenure. Such positions are subsumed as part of the postdoc phase.
} 
We conceptualize the academic career after obtaining a $\mathrm{PhD}$ in a life-cycle perspective of academic training and transitions to academic and non-academic jobs (figure 1). We focus on the postdoc phase and solve the decision problem backwards. The (present) value of a postdoc position $V_{p d}$ depends both upon the value of obtaining a tenured professorship with associated present value $V_{\text {prof }}$ and upon the value of a non-academic career with value $V_{2}^{n a}$. Both $V_{\text {prof }}$ and $V_{2}^{n a}$ are random variables for the postdoc. The transition probabilities along the academic career and the values of the two exits are affected by the training, the effort choice, and the working conditions during the postdoc phase.

The postdoc will choose the career path yielding the higher expected utility. When $V_{\text {prof }}$ exceeds $V_{2}^{n a}$, the postdoc makes the transition to a professorship at the next stage. Otherwise, he/she will eventually continue in a non-academic career. To model the effort decision during the postdoc phase, we specify

$$
V_{p d}=\max _{e}\left\{u(e, w c)+E \max \left[V_{p r o f}\left(e, w c, a_{a}\right), V_{2}^{n a}\left(e, w c, a_{n}\right)\right]\right\}
$$

where $u(e, w c)$ is the utility while being a postdoc and $E \max [$.$] is the ex ante expected$ value of the future career. $e$ denotes the effort of the postdoc and $w c$ denotes the working conditions of the postdoc. $a_{a}$ and $a_{n}$ are anticipated shift parameters which affect the relative attractiveness of a professorship or a non-academic career after a postdoc phase, respectively, with $\partial V_{\text {prof }} / \partial a_{a}>0$ and $\partial V_{2}^{n a} / \partial a_{n}>0$.

The probability for a postdoc to obtain a professorship is given by $P_{p d}($ prof $)=$ $P\left(V_{\text {prof }}\left(e, w c, a_{a}\right)>V_{2}^{n a}\left(e, w c, a_{n}\right) \mid\right.$ postdoc $)$. We assume that the postdoc chooses effort $e$ in order to maximize $V_{p d}$. We further assume that higher effort causes a disutility while being a postdoc $(\partial u(e, w c) / \partial e<0)$, but increases both future values $\left(\partial V_{\text {prof }} / \partial e>\right.$ $\left.\partial V_{2}^{n a} / \partial e>0\right)$, the effect being uniformly stronger for the professorship. ${ }^{2}$ Higher effort as a postdoc results in better training and higher research output for given working conditions. We assume that the higher effort also has a positive effect on $V_{2}^{n a}$ because the postdoc training creates useful human capital for the non-academic labor market (sic!).

We assume that the working conditions $(w c)$ are exogenous for the postdoc. ${ }^{3}$ They have a positive effect on the current utility $(\partial u(e, w c) / \partial w c>0)$ and on both future

\footnotetext{
${ }^{2}$ Here, and analogously in similar cases, we assume that $\partial V_{\text {prof }} / \partial e>\left(\partial V_{2}^{n a} / \partial e\right)+\delta$ for some small $\delta>0$ and that all value functions are continuously differentiable. Furthermore, the continuous joint density of $\left(V_{\text {prof }}\left(e, w c, a_{a}\right), V_{2}^{n a}\left(e, w c, a_{n}\right)\right)$ is uniformly positive for all values with $V_{\text {prof }}\left(e, w c, a_{a}\right)=$ $V_{2}^{n a}\left(e, w c, a_{n}\right)$. These conditions are sufficient for the formal results in the appendix.

${ }^{3}$ Obviously, this is a simplification since postdocs can search for a better postdoc position. Postdocs doing better research are more likely to find positions with better working conditions. In the field of economics, in fact, there exists a formalized international market for postdoc positions, which a number of leading economics departments in Germany participate in. Strictly speaking, our assumption refers to the working conditions in the current postdoc position.
} 
values with $\left(\partial V_{\text {prof }} / \partial w c>\partial V_{2}^{n a} / \partial w c>0\right)$. Better working conditions for research result in better training and higher research output for a given effort. Again, we assume that the effect is stronger for the professorship.

Furthermore, we assume that $\left(V_{\text {prof }}, V_{2}^{n a}\right)$ both take only positive values and that they follow a joint continuous probability distribution $f(x, y)$ for given $\left(e, w c, a_{a}, a_{n}\right)$ (we omit these arguments in the following discussion). The expected future value after the postdoc stage is then expressed by

$$
F V \equiv E \max \left[V_{\text {prof }}\left(e, w c, a_{a}\right), V_{2}^{n a}\left(e, w c, a_{n}\right)\right]=\int_{0}^{\infty} \int_{0}^{\infty} \max (x, y) f(x, y) d y d x
$$

and the probability to obtain a professorship is

$$
P_{p d}(\text { prof })=\int_{0}^{\infty} \int_{0}^{x} f(x, y) d y d x
$$

In the appendix, we formally show how these expressions respond to monotone shifts in one or both arguments of the probability distribution. Based on these results and some technical regularity conditions (see footnote 2), we can then unambiguously sign the effects of $e, w c, a_{a}$, and $a_{n}$ on both $F V$ and $P_{p d}$ (prof) as follows:

\begin{tabular}{c|cccc}
$u$ & $e$ & $w c$ & $a_{a}$ & $a_{n}$ \\
\hline$\frac{\partial F V}{\partial u}$ & $>0$ & $>0$ & $>0$ & $>0$ \\
$\frac{\partial P_{p d}(p r o f)}{\partial u}$ & $>0$ & $>0$ & $>0$ & $<0$ \\
\hline
\end{tabular}

$u$ denotes the arguments $e, w c, a_{a}, a_{n}$

We can now continue to analyze the effort choice of the postdoc. Under standard assumptions such as $\partial^{2} u(e, w c) / \partial e^{2}<0$ (increasing marginal disutility in effort) and $\partial^{2} V_{\text {prof }} / \partial e^{2}<0, \partial^{2} V_{2}^{n a} / \partial e^{2}<0$ (decreasing returns), there exists a unique interior solution for the effort choice characterized by $-\partial u(e, w c) / \partial e=\partial F V / \partial e$ (marginal disutility of effort is equal to marginal future value of higher effort). Assuming complementarity between effort and working conditions $w c$, i.e. $\partial^{2} u(e, w c) / \partial e \partial w c>0$ and $\partial^{2} V_{\text {prof }} / \partial e \partial w c>0, \partial^{2} V_{2}^{n a} / \partial e \partial w c>0$, we obtain the result that with better working conditions effort increases and, also taking the effort choice into account, the probability to obtain a professorship increases. Assuming complementarity between $e$ and the attractiveness parameters $a_{a}$ and $a_{n}$, i.e. $\partial^{2} V_{\text {prof }} / \partial e \partial a_{a}>0$ and $\partial^{2} V_{2}^{n a} / \partial e \partial a_{n}>0$, we find that effort increases unambiguously with higher attractiveness of an academic career $a_{a}$, whereas the effect on a non-academic career $a_{n}$ is ambiguous. Correspondingly, the probability to pursue an academic career increases with $a_{a}$ and it falls with $a_{n}$ (the latter result causes the ambiguity of the effect of $a_{n}$ on effort).

Our life-cycle framework emphasizes that the value of a non-academic career has an impact on the decisions of the postdocs while still pursuing their academic career. Two 
examples shall illustrate the point. First, if the type of research affects the value of the non-academic career, the postdoc may choose a more applied research agenda because it may pay off in the event he/she enters a non-academic career. Second, because research effort and working conditions positively affect the productivity in the non-academic career, this will reinforce the research incentives during the postdoc phase.

Analogous to the career decision of the postdoc, we sketch how to analyze the $\mathrm{PhD}$ phase and the decision to continue an academic career afterwards (see figure 1). In the German case, the majority of $\mathrm{PhDs}$ do not continue an academic career after completion of the $\mathrm{PhD}$ (BMBF, 2008). This means that the research effort and the choice of research topics during the PhD are both affected by academic and non-academic career prospects. Different fields may differ strongly with respect to the value of holding a PhD for a nonacademic career. It is often argued that among the fields considered in our study, the payoff of a $\mathrm{PhD}$ in a non-academic career is highest for business economics and lowest for sociology or social sciences. Clearly, the chances to pursue either an academic career or a non-academic career affect the career and research decisions during the $\mathrm{PhD}$ phase. A higher research effort and better working (research) conditions during the $\mathrm{PhD}$ phase will raise the future value of both the academic career and the non-academic career, with the positive effect being stronger for the academic career.

\subsection{Hypotheses}

Based on the theoretical framework, we develop a number of hypotheses to be explored in our empirical analysis.

The research output results in papers or monographs. This output depends upon the research effort and the working conditions of the postdoc. The university reforms of the last decade have intended to improve the working conditions of postdocs, in particular by introducing junior professorships (Bulmahn, 2001) and granting them more independence. Scientific networks play a special role for academic careers, and potentially also for the motivation of young academics. Postdocs who think that networks are more important than research effort for a successful academic career have less research incentives.

Hypothesis 1 (Incentives) Better working conditions in the current job enhance research incentives of postdocs. Junior professors have the highest research incentives. Research incentives are lower for postdocs who think that networks are more important for an academic career.

Our theoretical framework implies that the current prospects in the non-academic labor market and the future academic and non-academic career prospects affect the research 
and career decisions of a postdoc. Higher (international) competition reduces the chances to obtain a professorship, thus reducing the research effort of a postdoc (in Germany). However, higher (international) competition may raise the marginal return of research effort of a postdoc regarding the value of an academic career, thus resulting in higher research effort of postdocs.

Hypothesis 2 (Career Prospects) Better chances for a future academic career or a future non-academic career enhance research incentives of postdocs. Better chances for a nonacademic career at present reduce research incentives of postdocs. Better chances for a future non-academic career increase the research efforts in applied research as opposed to basic research. The effect of higher (international) competition for professorships on research effort is ambiguous. Better working conditions and higher research effort as a postdoc raise both the value of a future academic career and of a future non-academic career, with the effect being larger for an academic career.

Similar to the postdoc phase, the PhD phase in Germany has also been the subject of a reform debate (BMBF, 2008). In Germany, the age of completion of a $\mathrm{PhD}$ is very high in international comparison. Obtaining a $\mathrm{PhD}$ at a chair may result in less independence and less research orientation during the PhD stage. This may be (partly) compensated if a $\mathrm{PhD}$ candidate is better integrated in the research projects of the chair and the scientific network of the chair. It is a widely held view that the effectiveness of $\mathrm{PhD}$ training and mentoring is improved by the participation in structured doctoral programs (BMBF, 2008, p. 140). Furthermore, multiple supervisors and training in advanced research oriented course may improve the quality of $\mathrm{PhD}$ research and to speed up graduation.

Hypothesis 3 (PhD phase) Better supervision and mentoring as well as stronger involvement in the scientific community during the PhD phase raise the research effort of PhDs and shorten the time until completion of a PhD. Better working conditions and a higher research effort as a PhD raise both the value of a future academic career and of a future non-academic career for postdocs, with the effect being larger for an academic career. This results in higher research effort during the postdoc phase.

Women are less likely to continue an academic career after completion of the $\mathrm{PhD}$ and the average age at which postdocs obtain a professorship is particularly high in Germany (BMBF, 2008; Schulze et al., 2008). One explicit goal of the university reforms was to reduce the age of first appointment as professor (Bulmahn, 2001). Creating independent junior professorships with an associated time limit and greater independence should allow postdocs to focus more on excellent research. In particular, this should benefit female 
postdocs, for whom the difficulties to reconcile of family and career is a strong obstacle for an academic career. Having made the decision to work as a postdoc, female postdocs are likely to have a stronger research interest as they have higher opportunity costs of an academic career compared to males. Furthermore, females may see better opportunities to pursue an academic career if the male-female gap is higher in a non-academic career. However, females may be more risk averse than males in undertaking high-risk high-return research projects.

At higher age and in the presence of children, postdocs value current period utility more strongly than the future value of an academic and an non-academic career and find it more costly to get involved in the scientific community (see Chlosta et al., 2010 for a similar argument). Also, older cohorts are less likely to be affected by the university reforms. Furthermore, the higher the age, the more likely the postdoc may not have been considered for a professorship, resulting in older postdocs being more negatively selected.

Hypothesis 4 (Gender, Age/Cohort, Children) Research incentives fall with higher age and in the presence of children. The gender effect on research incentives is ambiguous, depending upon whether the positive selection of females or the higher opportunity costs of research for females dominates. Female postdocs, postdocs with children, and older postdocs are less willing to take risks and are more likely to engage in applied research.

Our empirical analysis comprises the fields of business economics, economics, sociology, and social sciences. By fields, the non-academic career prospects (expected earnings) are highest in business economics (Chlosta et al., 2010) and lowest in sociology and social sciences. Chairs in business economics have comparatively better contacts to private firms; thus resulting in better networks to pursue a non-academic career. In order to convince a $\mathrm{PhD}$ in business economics to pursue an academic career, working conditions as a postdoc and the value of a future academic career have to be even better than for the two other fields. The reverse argument should apply for sociology and social sciences.

Hypothesis 5 (Different academic fields) Postdocs in business economics (sociology and social sciences) have the highest (lowest) value of a non-academic career. Correspondingly, research effort is highest (lowest) in sociology and social sciences (business economics), while the effect of the field on the chances to obtain a professorhip is ambiguous. 


\section{$3 \quad$ Data and Descriptives}

\subsection{Description of Survey}

We conduct an email survey in September and October 2008 among postdocs who had a position at a German university in the fields of economics, business economics, sociology or social science. For the purpose of our survey, postdocs are defined as persons who hold a PhD degree, including junior professors, but who do not yet have a tenured professorship. Via an extensive internet research, we found eligible 1169 postdocs. As an incentive, the newspaper Handelsblatt sponsored a number of temporary free newspaper subscriptions, which were randomly distributed among the respondents. ${ }^{4} 47 \%$ of the postdocs (546 persons) completed the survey, $7 \%$ quit during the interview, and $46 \%$ did not respond at all. Unless indicated otherwise, we refer in the following to the sample of the 546 postdocs who completed the survey. We think the responses are quite reliable, as the topic of the survey is of high relevance for the respondents. Furthermore, it is an advantage that the data were collected some time after the university reforms of the last decade. There exists no comparable recent survey focusing on career prospects of postdocs in Germany.

The survey consists of two parts. The first part concerns information on the current postdoc position and on the academic background and assesses the academic and nonacademic career prospects as well as the general situation in academia. Some of the assessment questions use a five to six points Lickert scale. Additionally, a 'no answer'field was offered. Further questions involve statements the respondents could agree or disagree with (see Tables 11 and 12 in the additional appendix).

\subsection{Descriptive Statistics}

Table 1 summarizes key descriptive statistics of our data set; more detailed descriptive results can be found in the additional appendix. Among the 546 respondents, there are 360 males $(66 \%)$ and 186 females $(34 \%){ }^{5} 10 \%$ of the respondents hold a foreign citizenship. The average age in the sample is 38 . Females are slighty older than males and $10 \%$ of the postdocs are older than 45 years (Table 1 in the additional appendix). Around 50\% are married, another $30 \%$ live in a partnership, and around $40 \%$ have children. The distribution is quite similar for females and males (Table 2 in the additional appendix). Regarding the distribution of academic fields, about one-third graduated in Business Economics, a quarter in Economics, another quarter in Social Sciences or Sociology, and

\footnotetext{
${ }^{4}$ Handelsblatt published some descriptive results of the survey in 2009 (Heß, 2009).

${ }^{5}$ Six persons did not disclose their gender. We assume them to be females, because mostly females tend not to disclose their gender.
} 
the rest in Business related subjects such as Business Informatics, Industrial Engineering, and others. On average, it took 5.6 years to obtain the $\mathrm{PhD}$ after completion of the highest academic degree. 93\% obtained their PhD in Germany and around 70\% obtained their $\mathrm{PhD}$ while working at the chair of a professor. At the time of the survey, on average three years had passed since the completion of the $\mathrm{PhD}$. 50\% are now working at the university where they obtained their PhD. Most of the postdocs are research assistants (48\%) and/or have the status of a 'Habilitand' (42\%). Among the 225 postdocs pursuing a Habilitation only $25 \%$ are women (Table 4 in the additional appendix). Regarding the integration into the scientific community, $84 \%$ of all postdocs have attended national or international conferences, $29 \%$ have visited another research institution, $38 \%$ have written referee reports, $58 \%$ have published in peer-reviewed journals, and $54 \%$ have been engaged in a third-party-funded research project. Table 10 in the additional appendix shows that there are some gender differences in these activities, with females being more likely to go abroad for a research stay and males being more likely to write referee reports. We will analyze these gender differences further as part of the subsequent multivariate analysis.

Figure 2 depicts the distribution of assessments regarding research motivation and career prospects of the postdocs. $53 \%$ of all postdocs say that the research incentives in their current job are rather strong or very strong. Only $29 \%$ think that the university reforms of the last decade have improved these incentives, whereas $55 \%$ believe that incentives have improved due to stronger competition from outside Germany. Whereas $49 \%$ assess their current non-academic employment prospects to be very good or good, only $21 \%$ think that this will be the case in five years from now. At the same time, merely $48 \%$ of all postdocs view their own academic career prospects as very good or rather good and $76 \%$ say that the competition for an academic career in their field is very strong or strong. Furthermore, 25\% think that networks are more important for a successful career than academic excellence. $68 \%$ of all postdocs prefer an academic job at present and $66 \%$ expect to have an academic job in 5 years. $49 \%$ of all postdocs think that the current working conditions and the future employment prospects have a positive effect on the motivation to engage in an academic career. $51 \%$ of all postdocs say that the recent changes in career prospects have caused a shift towards applied research.

These findings provide a mixed picture of the research incentives, career plans, and career prospects of postdocs. On the one hand, the majority of postdocs is committed to an academic career, is to some degree integrated into the scientific community, thinks that the competition is hard, and is concerned about weak non-academic career prospects. On the other hand, the working conditions are often not conducive to excellent research and the university reforms have not improved the research incentives strongly enough. Due 
to career concerns, postdocs do more applied research, and networking is often perceived to be more important than academic excellence. Based on these findings, the newspaper Handelsblatt concluded that a lot of postdocs are frustrated (Heß, 2009).

\section{Cluster Analysis of Researcher Types}

Next, we identify groups of postdocs based on their assessment of research motivation and career prospects. A k-means cluster analysis with 10.000 iterations and the Jaccard similarity measure was used to identify three types of researchers. Methodologically, as initial group centers the last three observations of our dataset were used. We experimented with different numbers of clusters, before we concluded that three clusters represent most of the data well. In total, the cluster analysis assigns 447 postdocs to the three clusters. The first cluster (Type frustrated pessimists) comprises 33\% of the postdocs, the second $32 \%$ (Type motivated optimists), and the third 36\% (Type confident academics), see Table 2. We labeled the clusters in light of the average responses given. Table 3 shows that the motivated optimists have the strongest research incentives and expect good career prospects. Their research motivation improves strongly by increased competition outside and slightly by the university reforms. In comparison, the group of confident academics has high research incentives as well but both confident academics and frustrated pessimists see low non-academic career prospects. Furthermore, almost all confident academics and motivated optimists prefer an academic job now and also expect to have an academic job in five years. The frustrated pessimists differ strongly from the two other types. Among them, research incentives and academic as well as non-academic career prospects are very weak. Also, the frustrated pessimists report the weakest increase of research motivation due to the university reforms. Alltogether, the frustrated pessimists have a low research motivation and a very pessimistic assessment of their academic career prospects.

We analyze the differences in the composition of the researcher types (clusters) in Table 4. Overall, the share of females is lowest among the motivated optimists and quite similar among the two other types. The age distribution differs strongly. Motivated optimists are considerably younger and confident academics are on average the oldest. The optimism among the former group may be related to the fact that non-academic career prospects deteriorate with age. In contrast, confident academics are aware of the low non-academic career prospects at higher age, but are confident with respect to their academic career. Regarding fields, business economics is represented strongest among the motivated optimists (44\%) and sociology/social sciences among the confident academics $(30 \%)$. Most of the postdocs who did their $\mathrm{PhD}$ at the chair of a professor are to be found 
among the frustrated academics, whereas graduates of a $\mathrm{PhD}$ program are most strongly represented among the motivated optimists. Similarly, the current position differs strongly across researcher types. Whereas there are almost no assistant professors among the frustrated academics, research assistants are most strongly represented among this group. Those aiming for a Habilitation are mostly motivated optimists and academic lecturers ('Akademischer Rat/Rätin') have the lowest share among the frustrated academics.

\section{Econometric Analysis}

We explore the hypotheses presented in section 2.3. We focus on binary probit regressions to acount for key differences. The dependent variable is recoded as a dummy variable, where one extreme category of interest and the closest to it (e.g. very good and rather good) are recoded as one and the three remaining categories (e.g. neutral, rather bad, very bad) as zero. The categorical assessment variables used as control variables in our regressions are defined such that the two extreme categories and the closest to it are recoded as -1 or +1 , respectively, with the middle category being 0 . To investigate the robustness of our results, we also estimate ordered probit regressions which we report in the additional appendix.

For some key relationships, we consider three different specifications. The first and most parsimonious specification controls only for personal background variables as gender, age, family status, subject of highest academic degree before $\mathrm{PhD} / \mathrm{of} \mathrm{PhD}$, and years since completion of highest academic degree/PhD graduation. The second specification additionally includes the type of position, information about the $\mathrm{PhD}$ phase and about the integration into the scientific community. The most comprehensive third specification further adds some categorial assessment variables and interaction effects of all control variables with gender. While we keep all control variables as linear effects, we only keep those interactions which are significant at conventional levels. All control variables (except the female dummy) are normalized as differences from their averages among females such that, in the presence of interaction effects, the 'average probit coefficient' of the dummy for female reflects the average gender difference. To discuss the estimation results, we mainly rely on the estimated average marginal effects (AME) of the control variables. We explain this more formally in the appendix.

Note that our subsequent results are descriptive in nature, i.e. they may partly reflect reverse causality or selection effects. To give one example, participants of $\mathrm{PhD}$ programs may be selected into such programs because they are more research oriented, i.e. $\mathrm{PhD}$ programs may not necessarily cause higher research incentives. The goal of our analysis is 
simply to describe and interpret these relationships in light of the hypotheses put forward above. In fact, these hypotheses often concern the direction of the association between two endogenous variables.

\subsection{Research Incentives}

Our conceptual framework in section 2.2 focuses on the effort decision of the postdoc. As reported above, $53 \%$ of the postdocs report rather strong or very strong research incentives, i.e. for $47 \%$ of the postdocs pursuing an academic career, research incentives are only average or weak. We explore to what extent research incentives are associated with working conditions, background variables, and career prospects.

Table 5 reports the coefficient estimates of probit regressions of various covariates on research incentives. The most parsimonious specification (1) only shows significant effects for 'PhD in Germany' and Business Economics, i.e. research incentives are weaker among those postdocs who did their PhD in Germany and those postdocs who work in Business Economics. However, these significant effects disappear in the more comprehensive specifications (2) and (3). When conditioning on the position, the $\mathrm{PhD}$ background, and the integration into the scientific community, specifications (2) and (3) show that females, assistant professors, and participants in $\mathrm{PhD}$ programs report significantly higher research incentives, while those who did their $\mathrm{PhD}$ at their current university report significantly lower research incentives. ${ }^{6}$ Recall that these estimates may very well reflect selection effects such that e.g. participants of PhD program have a priori higher research incentives in comparison. Even in such a case, the positive association found is interesting, thus suggesting that those with higher research incentives prefer PhD programs.

Specification (3) further includes the assessments of career prospects, academic competition, and the importance of networks. In addition to the significant effects already obtained for specification (2), we find that females who have been involved in third-partyfunded projects show significantly higher research incentives. The same holds for the perception of better academic career prospects, higher competition, and for female postdocs who feel that their working conditions improve their academic career. On the contrary, participation at national conferences and the perception that networks are more important than academic excellence are associated with significantly lower research incentives. Non-academic career prospects show no significant effects and there are no significant differences across fields. Table 6 shows the AME's for specification (3). Participation in

\footnotetext{
${ }^{6}$ Also, those with a missing or nonstandard $\mathrm{PhD}$ background report significantly higher research incentives in specification (2), but not in specification (3). We do not comment on this result as this group involves only $4 \%$ of all observations (Table 6 in the additional appendix).
} 
a $\mathrm{PhD}$ program is associated with a 22 percent point (ppt) higher probability for strong research incentives. The AME's for 'academic career prospects' and 'strong competition' are 8 ppts and 10 ppts, respectively, and the perception that working conditions improve academic career show an AME of 14 ppts. The perception that networks are more important than academic excellence is associated with a reduction of 16 ppts. For instance, $49 \%$ feel that their working conditions positively affect their academic career and $29 \%$ report this effect to be negative (Figure 2). Thus, our regression estimates explain sizeable differences in research incentives. These results provide evidence supporting hypothesis 1 . So far, the evidence on hypothesis 2 is mixed. On the one hand, we find positive effects of academic career prospects, which is in accordance with hypothesis 2 . On the other hand, current and future non-academic career prospects do not affect research incentives, thus contradicting hypothesis 2 .

As reported above, only $29 \%$ of the respondents think that the university reforms of the last decade have improved their incentives (Figure 2). Table 6 reports the estimated AME's for a probit regression of the dummy 'reforms improved incentives'. We find significantly negative effects of age, research assistant, habilitation status, and of the perception that networks are more important than academic excellence. In contrast, there are strong significantly positive effects for assistant professors and for those who think that working conditions improve the academic career. The age effect is as expected as older postdocs are less likely to be affected by the reforms. The same holds for those who are in a traditional postdoc position (research assistant, habilitation). At the same time, these groups may be negatively affected by the increased competition of those benefitting from the reforms (assistant professors) and by the deterioration of the attractiveness of an academic career because of the lower base salaries for $\mathrm{W}$-professors. In contrast, assistant professors, whose positions were introduced by the reform, those with a positive view of conditions improving the academic career, and those who think that networks are not more important than academic excellence are more likely to say that the reforms improved incentives. This confirms the finding of the cluster analysis that the motivated optimists show the best assessment of the effects of the reforms on research incentives (Table 3).

Hypothesis 2 is agnostic about the direction of the association between increased competition and research incentives. The results so far show that strong academic competition is associated with higher research incentives. Table 6 shows the estimated AME's for a regression of the dummy variable indicating whether competition from outside improves incentives. Again, we find significantly negative effects for age, the network variable, and $\mathrm{PhD}$ at the current university. Competition, academic prospects, and the perception that working conditions improve academic career show a significantly positive associa- 
tion. These results are in line with the discussion so far. The results also reveal strong differences across fields, with postdocs in economics saying most strongly and postdocs in sociology/social science least strongly that international competition improves incentives. With a difference of more than 30 ppts, the gap across fields is very strong. The strongest effect exists for postdocs in economics and the smallest one for sociology/social sciences.

\subsection{Career Prospects}

As reported above, more than $50 \%$ of the postdocs are pessimistic about their academic career (Figure 2), which according to our theoretical expectations leads to lower research incentives.

Table 7 reports the estimated AME's for probit regressions of academic and nonacademic career prospects. We first consider academic career prospects. Living in a partnership and having children are associated with significantly lower career prospects (note that 'married' is the omitted category), e.g. having two children decreases the probability of good academic career prospects by 18 ppts. Assistant professor and habilitation is associated with significantly higher academic career prospects, with assistant professors showing the highest confidence. Some indicators of integration into the scientific community (national conferences, publications) are also associated with significantly higher prospects while a research stay in Germany is associated with lower prospects. Stronger competition and the perception that networks are more important than academic excellence are associated with significantly lower prospects, while those with a positive view of conditions improving the academic career report significantly better prospects. Clearly, the latter effects should not be interpreted in a causal way because optimism may be reflected in these variables and in the dependent variable. ${ }^{7}$ Non-academic career prospects show no significant effects.

Turning to non-academic career prospects, $49 \%$ of all postdocs assess their current non-academic employment prospects to be very good or good and only $21 \%$ think that this will be the case five years from now (Figure 2). Table 7 reports a significantly and sizeable negative age effect for current non-academic career prospects, but no age effect for prospects in five years. Germans have significantly better current prospects, but there is no such effect in 5 years. Incidently, postdocs with a Master degree show significantly worse current prospects, but significantly better prospects in 5 years. This is difficult to explain. In addition, assistant professors and those having stayed at a German

\footnotetext{
${ }^{7}$ The effect of the perception of networks could be affected by a so-called 'Justification Bias'. A postdoc who believes that his/her chances for an academic career are bad, may 'explain' (rationalize) this with the importance of networks and not with his/her own lack of success.
} 
research institute show significantly worse current prospects and no significant effects on prospects in 5 years. Academic career prospects show no significant effects whereas strong academic competition is associated with worse prospects in 5 years, possibly because the postdocs fear that, due to the strong competition for academic positions, there will be more competition for non-academic jobs in 5 years. Also, those with a positive view of 'conditions improving the academic career' report significantly better non-academic career prospects in 5 years, but no better current non-academic career prospects. This finding is in accordance with hypothesis 2. As expected, postdocs in sociology/social sciences report significantly worse current non-academic career prospects. However, there is no such effect for career prospects in 5 years. Overall, the lower non-academic career prospects in 5 years are less affected by the characteristics of the postdocs compared to current prospects. Most postdocs, irrespective of their background, seem to acknowledge that their non-academic career prospects in 5 years are only average or below average. The lack of coherent significant effects for indicators of the integration into the scientific community on research incentives and career prospects are difficult to rationalize and, thus, cast some doubt regarding hypotheses 1 and 2 .

As mentioned before, a key question in the survey relates to whether the conditions in the current job and the future employment prospects affect the motivation and incentives ('conditions improve academic career'). This variable is strongly associated with research incentives and career prospects and $49 \%$ see a positive relationship. The probit regression results (Table 23 in the additonal appendix) show that only career prospects (positive effects) and the perception that networks are more important than academic excellence (negative effect) are significantly associated with this variable. These findings provide further evidence for hypotheses 1 and 2. A majority of postdocs (69\%) would still select an academic research job at present if given the choice, and a majority of postdocs expects to have an academic research job in 5 years. There are some interesting differences (Table 23 in the additonal appendix). Better non-academic career prospects and the perception that networks are more important than academic excellence are associated with a significantly lower desirability/probability of an academic job at present and in five years, whereas better academic career prospects show a significantly positive association. Assistant professors expect a higher probability of an academic job in 5 years but there is no such effect at present. The habilitation status shows an even stronger significantly positive effect both at present and in 5 years. These results are even more remarkable in light of the finding that habilitation status and assistant professorship show a significantly positive association with the perception of strong competition in the field (Table 25 in the additional appendix). In contrast, there are no corresponding effects on the perception 
that networks are more important than academic excellence.

In accordance with hypothesis 2 , the type of research is affected by the goal to improve non-academic career prospects: more than $50 \%$ of the postdocs report that the recent changes in the career prospects of young academics induced a shift more towards applied research and over $40 \%$ say that they actually pursue applied research in order to improve their non-academic career prospects (Figure 2). Probit regression results show that better non-academic career prospects and the perception that networks are more important than academic excellence are associated with a higher probability to pursue applied research in order to improve non-academic career prospects (Table 24 in the additional appendix). This probability is significantly lower for postdocs in sociology or social sciences and for older postdocs.

Our survey also involves a number of statements with which the respondents could agree with (Table 11 in the additional appendix). 42\% (51\%) of the respondents agree with the statement that many established (young) academics leave German universities because of the moderate salaries. The approval rate for the statement that insecure working prospects cause many young academics to leave German universities is $78 \%$. $60 \%$ agree with the statement that an academic job is more risky than a non-academic job. $61 \%$ perceive the lack of a tenure-track option as a flaw of the introduction of assistant professorships. Once again, these results confirm that a majority of postdocs is very concerned about insufficient career prospects in Germany, with likely negative effects on research incentives. These results provide further support for hypotheses 1 and 2 .

\subsection{PhD Background}

The $\mathrm{PhD}$ phase paves the way for an academic career. We now discuss specifically the effect of the PhD background. Note that $68 \%$ of the postdocs in our sample did their $\mathrm{PhD}$ at the chair of a professor, whereas $12 \%$ obtained their $\mathrm{PhD}$ through a $\mathrm{PhD}$ program, $7 \%$ were at a research institution, and 9\% were external doctoral candidates (Table 1 and Table 6 in the additional appendix).

Those who went through a $\mathrm{PhD}$ program show significantly higher research incentives (Table 5 and 6). The average marginal effect is 22 ppts compared to a $\mathrm{PhD}$ obtained at a chair. These results are in accordance with hypothesis 3. Furthermore, former participants of $\mathrm{PhD}$ programs are more convinced that stronger international competition improves research incentives (Table 6) and report significantly better non-academic career prospects at present (Table 7). However, the variable does not show any significant effect on academic career prospects and non-academic career prospects in 5 years. Postdocs who did their $\mathrm{PhD}$ at the university they are currently working at show significantly lower 
research incentives and are significantly less convinced that international competition improves research incentives (Table 6). The variable shows no significant effect on the career prospects. This provides some evidence for hypothesis 3 ; however, but the lack of significant effects on academic career prospects is in contrast to hypothesis 3 . We find no significant differences in the assessment of the strength of competition and in the perception that networks are more important than academic excellence (Table 25 in the additional appendix).

Overall, we find some evidence supporting hypothesis 3. The most important result is that a $\mathrm{PhD}$ obtained in a $\mathrm{PhD}$ program dominates the $\mathrm{PhD}$ at a chair of a professor in terms of research incentives and current non-academic career prospects. These results are consistent with the view that participation in a $\mathrm{PhD}$ program results in better supervision and mentoring and that it shortens the time until completion of the $\mathrm{PhD}$.

\subsection{Gender, Age, Children}

Gender and having children are likely to play an important role in the decision for an academic career, as formulated by hypothesis 4 . We review the results obtained so far under this perspective. Female postdocs show significantly better research incentives (Table 6), but otherwise we find little gender differences (except for some significant interaction effects) in the assessment of reforms, the impact of competition, and career prospects (Tables 6, 7 and Tables 23, 25 in the additional appendix). At the same time, the share of females is lowest among the motivated optimists and highest among the confident academics identified in section 4.

The regression results reported in Tables 16 and 18 in the additional appendix reveal that the positive association of the variable 'conditions improve academic career' with career prospects is almost exclusively due to such an effect for females. Furthermore, the perception that networks are more important than academic excellence does not play any role for academic career prospects of female postdocs. The contrary is true for male postdocs. Possibly, enthusiasm plays a stronger role for those females who continue an academic career. These results are consistent with female postdocs being a positive selection in accordance with hypothesis 4 . In contrast to hypothesis 4, females do not agree to a larger extent to the assessment that an academic research job is more risky than a job outside of academic research (Table 20 in additional appendix) - the insignificant point estimate would even imply the opposite. Again, this may be rationalized by female postdocs being a positive selection.

The effects of children and partnership are mostly insignificant, with some notable ex-

ceptions. Table 7 shows that academic career prospects are significantly worse for postdocs 
with children and for postdocs living in a partnership (note that there is no significant interaction with gender). Correspondingly, Table 24 in the additional appendix shows that postdocs living in a partnership (but not postdocs with children) are significantly more likely to engage in applied research to improve their non-academic career prospects. Table 25 in the additional appendix shows that both singles and postdocs with children are significantly more likely to say that competition is strong. These findings and the lack of significance of interaction effects with gender in most cases, provide only mixed support for hypothesis 4 .

Now, we turn to the effects of age. Table 6 shows that age has no significant effect on research incentives (again in contradiction to hypothesis 4). However, age proves significantly negative in a number of cases. At higher age, there is less agreement that the reforms and international competition improved incentives (Table 6). This is to be expected because the reforms were implemented when the older postdocs had already made important career steps. Correspondingly, postdocs at a middle-age (33-44 years) most strongly agree with the statement that the introduction of junior professorship is flawed since most assistant professorships do not involve a tenure-track option (Table 11 in the additional appendix). Non-academic career prospects deteriorate at higher age (Table 6) and there is a shift towards applied research to improve non-academic career prospects (Table 24 in the additional appendix). Postdocs at a higher age agree to a larger extent to the assessment that an academic research job is more risky than a job outside of academic research (Table 20 in additional appendix), however, the effect is quite small and insignificant. Overall, the age effects are mostly in accordance with hypothesis 4 . In particular, concerns about non-academic career prospects, but not about academic career prospects, increase with age. This is in line with the finding that motivated optimists are younger and confident academics are older (section 4).

\subsection{Different Academic Fields}

Our survey involves postdocs from different academic fields with presumably very different non-academic career prospects. We find some remarkable differences across fields. Postdocs in sociology/social sciences are the most concerned about insecure working prospects, postdocs in business economics are the most concerned about the low salaries for young academics, and economists are the most concerned about the lack of the tenure-track options for assistant professors (Table 12 in the additional appendix, statements 6, 5, 8). For the regression results, economics is taken as the omitted category. We review the results obtained so far regarding different academic fields.

Most importantly, research incentives do not differ significantly across fields (Table 
6 ), which is in contrast to hypothesis 5. Incidently, we find only a small number of cases with significant differences across fields. Economists see a stronger impact of international competition on incentives (Table 6) and, in accordance with hypothesis 5, the perception of non-academic career prospects is significantly lower in sociology/social sciences than in the other fields (Table 7). Postdocs in business economics are more likely to choose an academic job again, if they could choose again, and expect a higher probability of an academic job in 5 years (Table 23 in the additional appendix). Postdocs in sociology/social sciences are more likely to undertake applied research to improve their non-academic career prospects (Table 24 in the additional appendix). Economists are the least likely to say that networks are more important than academic excellence, a finding which is in accordance with the finding of Schulze et al. (2008), that the academic market is more competitive in economics than in business economics.

Overall, research effort does not differ across fields despite differences in non-academic career prospects. Most likely there are important selection effects across fields. Postdocs in business economics are committed to an academic career and they see very good academic career prospects, possibly, because their less committed competitors have left an academic career after a PhD. Postdocs in sociology/social sciences are also committed to their more risky academic career (partly by intrinsic motivation) and they perceive poor nonacademic career prospects. In response, they are more likely to shift towards more applied research.

\section{Conclusions}

This paper is based upon a survey among postdocs in Germany, conducted for the fields of business economics, economics, sociology, and social sciences. We first develop a number of hypotheses regarding career transitions after the completion of a $\mathrm{PhD}$ based on a theoretical framework. Our framework emphasizes the interaction between academic and non-academic career paths. Based on the survey data, we analyze the research incentives, the academic background, and the career prospects of the postdocs.

Our results show quite a mixed picture of the sentiments among postdocs in Germany. Through a cluster analysis, we were able to identify three important types of postdocs: motivated optimists, who are younger and optimistic about their academic and non-academic career, confident academics, who are older, optimistic about their academic career, but pessimistic about their non-academic career, and frustrated pessimists, who are pessimistic about career prospects in general. Only about half of the postdocs sees strong incentives for academic research but there is quite strong confidence to succeed in 
an academic career. Also about half of the postdocs says that working conditions and future career prospects increase the motivation to engage in an academic career. There is evidence that research incentives increase due to stronger international competition. Employment insecurity is associated with a more pessimistic assessment of an academic career. The strongest research incentives and the best career prospects were found for assistant professors, which may be due to the specific selection of this group. Apart from this small group, the postdocs see only a small influence of the university reforms of the last decade on incentives and prospects of the researchers. Specifically, the university reforms were more negatively assessed by older postdocs. Both younger and older academics view their non-academic career prospects to deterioate over time. For postdocs in business economics, we find better non-academic career prospects than in other fields, and there is no evidence for falling research incentives due to better non-academic career prospects. The perception that networks are more important than academic excellence is negatively associated with research incentives and career prospects. Finally, assistant professors, graduates of $\mathrm{PhD}$ programs, but also postdocs who pursue a habilitation mostly show better outcomes than others. Clearly, the specific working conditions of a postdoc matter. Female postdocs show better research incentives but otherwise we find little gender differences. For both males and females, the presence of children is associated with worse career prospects.

\section{References}

Bareither, I. (2008, 17/09). "Wenig Geld und viele Umzüge". Handelsblatt.com. www.handelsblatt.com/technologie/forschung-medizin/forschung-innovation/weniggeld-und-viele-umzuege/3022532.html?p3022532=all, [Download: 18 October 2011].

BMBF (2008). "Bundesbericht zur Förderung des Wissenschaftlichen Nachwuchses (BuWiN)". Bundesministerium für Bildung und Forschung (Hrsg.), Berlin.

Buchholz, K., S. Gülker, A. Knie, and D. Simon (2009). "Attraktivität von Arbeitsbedingungen in der Wissenschaft im internationalen Vergleich". Wissenschaftszentrum Berlin für Sozialforschung (WZB), Berlin.

Bulmahn, E. (2001). "Leistungsorientierte Entlohnung - kann die geplante Dienstrechtsreform die Abwanderung von qualifizierten Nachwuchswissenschaftlern verhindern?". ifo Schnelldienst 8, Jhg. 54, 5-7. 
Burkhardt, A. (2011). "Bewundert viel und viel gescholten - Aktuelles vom Arbeitsplatz Hochschule". In Traumjob Wissenschaft?, Volume 117, pp. 19-29. W. Bertelsmann Verlag, Bielefeld.

Chlosta, K., K. Pull, M. Fiedler, and I. Welpe (2010). "Should I stay or should I go? Warum Nachwuchswissenschaftler in der Betriebswirtschaftslehre das Universitätssystem verlassen". Zeitschrift für Betriebswirtschaft (ZFB) 80, 1207-1229.

Dohmen, T. and A. Falk (2011). Performance Pay and Multi-dimensional Sorting: Productivity, Preferences and Gender. American Economic Review 101(2), 556-590.

Enders, J. and L. Bornmann (2002a). "Internationale Mobilität bundesdeutscher Promovierter - Eine Sekundäranalyse der Kasseler Promotionsstudie". Mitteilungen aus der Arbeitsmarkt- und Berufsforschung 35(1), 60-73.

Enders, J. and L. Bornmann (2002b). "Übergangsverläufe und Statuspassagen nach der Promotion". In M. Wingens and R. Sackmann (Eds.), Bildung und Beruf - Ausbildung und berufsstruktureller Wandel in der Wissensgesellschaft, pp. 159-176. Juventa Verlag, Weinheim und München.

Fitzenberger, B. (2008). "Comment to Job Market Effects on Scientific Productivity". In Scientific Competition, Volume 5, pp. 31-34. Mohr Siebeck, Tübingen.

Fox, M. and P. Stephan (2001). "Career of Young Scientists Preferences, Prospects and Realities by Gender and Field". Social Studies of Science 31, No.1, 109-122.

Gillmann, B. (2006, 12/09). "Man fühlt sich wie der Kaiser". Handelsblatt.com. www.handelsblatt.com/archiv/man-fuehlt-sich-wie-der-kaiser/2705506.html, [Download: 18 October 2011].

Gülker, S. (2011). "Karrierestrukturen in der Wissenschaft: Stand und Zukunftsbedarf". In Traumjob Wissenschaft?, Volume 117, pp. 31-44. W. Bertelsmann Verlag, Bielefeld.

Handelsblatt (2009, 08/06). "Hochschulen registrieren Professoren-Schwund". Handelsblatt.com. www.handelsblatt.com/politik/konjunktur/nachrichten/hochschulenregistrieren-professoren-schwund/3193586.html, [Download: 18 October 2011].

Heining, J., J. Jerger, and J. Lingens (2007). "Success in the Academic Labour Market for Economists - The German Experience". University of Regensburg Working Papers in Business, Economics and Management Information Systems No. 422. 
Heining, J., J. Jerger, and J. Lingens (2008). "Deutsche Hochschulkarrieren im Fach Volkswirtschaftslehre. Eine deskriptive Analyse von Lebenslaufdaten". Perspektiven der Wirtschaftspolitik 9(3), 306-328.

Heß, D. (2009, 22/02). "Frust im Elfenbeinturm". Handelsblatt.com. $\quad$ www.handelsblatt.com/politik/oekonomie/nachrichten/frust-imelfenbeinturm/3116846.html?p3116846=0, [Download: 1 March 2009].

Jaksztat, S. and K. Briedis (2009). "Studienstrukturreform und berufliche Situation aus Sicht des wissenschaftlichen Nachwuchses". Hochschul-Informations-System: Projektbericht, April 2009.

Jaksztat, S., N. Schindler, and K. Briedis (2010). "Wissenschaftliche Karrieren". Hochschul-Informations-System: Forum Hochschule No. 14.

Janson, K., H. Schomburg, and U. Teichler (2007). "Wege zur Professur. Qualifizierung und Beschäftigung an Hochschulen in Deuschland und den USA". Waxmann Verlag, Münster.

Jung, S. (2011). "Unbefristet, perspektivenreich, frauenfreundlich? Karrieren im Wissenschaftssystem und ihr Gender-Bias". In Traumjob Wissenschaft?, Volume 117, pp. 31-44. W. Bertelsmann Verlag, Bielefeld.

Leffers, J. (2007, 11/10). "Lebt denn d'r alte Habilitand noch?". Spiegel Online. www.spiegel.de/unispiegel/jobundberuf/0,1518,510857,00.html, [Download: 18 October 2011].

Lindley, J. and S. Machin (2011). "Rising Wage Inequality and Postgraduate Education". IZA Discussion Paper No. 5981.

Prußky, C. (2008, 13/03). "Wie geht es Ihnen, Dr. Unsicht?". Spiegel Online. www.spiegel.de/unispiegel/jobundberuf/0,1518,537970,00.html, [Download: 18 October 2011].

Rauber, M. and H. Ursprung (2008a). "Evaluation of Researchers: A Life Cycle Analysis of German Academic Economists". In Scientific Competition, Volume 5, pp. 101-122. Mohr Siebeck, Tübingen.

Rauber, M. and H. Ursprung (2008b). "Life Cycle and Cohort Productivity in Economic Research: The Case of Germany". German Economic Review 9(4), 431-456. 
Schulze, G. (2008). "Tertiary Education in a Federal System: The Case of Germany". In Scientific Competition, Volume 5, pp. 35-66. Mohr Siebeck, Tübingen.

Schulze, G., S. Warning, and C. Wiermann (2008). "What and How Long Does It Take to Get Tenure? The Case of Economics and Business Administration in Austria, Germany and Switzerland". German Economic Review 9(4), 473-505.

StBA (2011, 29/06). "Zahl der Habilitationen 2010 wieder gesunken". Statistisches Bundesamt Deutschland. www.destatis.de/jetspeed/portal/cms/Sites/destatis/Internet/DE/Presse/pm/2011/06/, [Download: 25 January 2012].

Stephan, P. (2008). "Job Market Effects on Scientific Productivity". In Scientific Competition, Volume 5, pp. 11-30. Mohr Siebeck, Tübingen.

Zoske, S. (2008, 05/03). "Das W-Prinzip: Geld gegen Leistung". Frankfurter Allgemeine Zeitung. www.faz.net/aktuell/beruf-chance/campus/professorenbesoldung-dasw-prinzip-geld-gegen-leistung-1515576.html, [Download: 18 October 2011].

\section{Appendix}

\section{Formal Results for the Life-cycle Phase Model}

Assume $(X, Y)$ are non-negative random variables with joint continuous probability density function (pdf) $f(x, y)$ and define

$$
F V=E \max [X, Y]=\int_{0}^{\infty} \int_{0}^{\infty} \max (x, y) f(x, y) d y d x
$$

and

(4) $\quad P=P(X>Y)=\int_{0}^{\infty} \int_{0}^{x} f(x, y) d y d x$.

We analyze the change in $F V$ and $P(X>Y)$ in response to two types of monotone shifts in the joint distribution of $(X, Y)$. These results are summarized by the following theorem.

Theorem: Consider a uniform rightward shift of $X$ and $Y$, i.e. $X^{\prime}=X+a(X, Y)$ with $a(x, y)>0$ for all $x, y, Y^{\prime}=Y+b(X, Y)$ with $b(x, y) \geq 0$ for all $x, y$, and $a(x, y)>$ $b(x, y)+\delta$ for some small $\delta>0$. In response to this shift, $F V$ strictly increases and $P$ does not fall. If in addition, for each $\delta>0$, there exists $\epsilon>0$, such that $P(|X-Y|<\delta)>\epsilon$, then $P$ strictly increases as well. 
Proof: Note that

$$
\begin{aligned}
& F V\left(X^{\prime}, Y^{\prime}\right)=\int_{0}^{\infty} \int_{0}^{\infty} \max (x+a(x, y), y+b(x, y)) f(x, y) d y d x \\
& >\int_{0}^{\infty} \int_{0}^{\infty} \max (x, y) f(x, y) d y d x
\end{aligned}
$$

because $\max (x+a(x, y), y+b(x, y))>\max (x, y)$ for all $x, y$. This shows that $F V$ strictly increases.

Further note that

$$
P\left(X^{\prime}>Y^{\prime}\right)=\int_{0}^{\infty} \int_{0}^{\infty} f(x, y) I[y+b(x, y)<x+a(x, y)] d y d x
$$

where $I($.$) denotes the indicator function. Clearly, y \leq x$ implies that $y+b(x, y)<$ $x+a(x, y)$. Thus, $P\left(X^{\prime}>Y^{\prime}\right) \geq P(X>Y)$. In addition, there exists cases for which $y>x$ and $y+b(x, y)<x+a(x, y)$ because $a(x, y)>b(x, y)+\delta$. As $P(|X-Y|<\delta)>\epsilon$, we know that $P\left(X^{\prime}>Y^{\prime}\right)$ increases at least by $\epsilon$, i.e. $P\left(X^{\prime}>Y^{\prime}\right)-P(X>Y)>\epsilon$.

Corrolary: Consider a rightward shift of $X$, i.e. $X^{\prime}=X+a(X, Y)$ with $a(X, Y)>0$, and $Y$ remains unchanged. In response to this shift, $F V$ strictly increases and $P$ does not fall. If in addition, for each $\delta>0$, there exists $\epsilon>0$, such that $P(|X-Y|<\delta)>\epsilon$, then $P$ strictly increases as well.

This Corollary follows immediately as a special case of the above Theorem.

\section{Probit Regression, Interaction Effects, and Marginal Effects}

To clarify our estimation results, let us say that we estimate a probit model based on a sample of size $N$ as

$$
P\left(Y=1 \mid x_{i}, D_{i}\right)=\Phi\left(\beta_{1}+\beta_{2} x_{i}+\beta_{3} D_{i}+\beta_{4} x_{i} D_{i}\right),
$$

where $\Phi$ is the cumulative standard normal distribution, $x_{i}$ is a normalized control variable, and $D_{i}$ is the gender dummy. We define $x_{i}$ as deviations from the average of the original control variable in the subsample of females, i.e. $\sum_{D_{i}=1} x_{i}=0$. Then, $\beta_{3}$ is the average effect of the female dummy $D_{i}$, i.e. the average marginal effect on the argument of the $\Phi($.$) function, because \beta_{3}=1 / N_{1} \sum_{D_{i}=1}\left(\beta_{3}+\beta_{4} x_{i}\right)$ and $N_{1}$ is the number of females. The interpretation of the coefficient for $x_{i}$ is as usual, with $\beta_{2}$ being the coefficient for males and $\beta_{2}+\beta_{4}$ being the coefficient for females.

To discuss the estimation results, we report the following estimated average marginal effects (AME)

$$
A M E(x)=\frac{1}{N} \sum_{i=1}^{N} \frac{\partial P\left(Y=1 \mid x_{i}, D_{i}\right)}{\partial x_{i}}=\frac{1}{N} \sum_{i=1}^{N} \phi\left(\beta_{1}+\beta_{2} x_{i}+\beta_{3} D_{i}+\beta_{4} x_{i} D_{i}\right)\left(\beta_{2}+\beta_{4} D_{i}\right),
$$

assuming a continuous $x$-variable and $\phi$ denoting the density of the standard normal. For the dummy variable $D_{i}$, we report

$$
A M E(D)=\frac{1}{N} \sum_{i=1}^{N}\left[P\left(Y=1 \mid x_{i}, D=1\right)-P\left(Y=1 \mid x_{i}, D=0\right)\right]
$$




$$
=\frac{1}{N} \sum_{i=1}^{N}\left[\Phi\left(\beta_{1}+\beta_{2} x_{i}+\beta_{3}+\beta_{4} x_{i}\right)-\Phi\left(\beta_{1}+\beta_{2} x_{i}\right)\right] .
$$

When $x$ is a dummy variable, we estimate $A M E(x)$ analogous to equation (7). When $x$ is a categorical variable with more than two outcomes, we rely on equation (6) as an approximation.

\section{Tables and Figures}

Table 1: Descriptive statistics for the 546 respondents who completed the survey

\begin{tabular}{lccccc} 
Variable & Mean & Std.Deviation & Min & Max & No. Answers $^{a}$ \\
\hline Male (Dummy) & 0.66 & 0.47 & 0 & 1 & 546 \\
Age & 38 & 6.35 & 25 & 72 & 546 \\
Married (Dummy) & 0.47 & 0.5 & 0 & 1 & 546 \\
Partnership (Dummy) & 0.31 & 0.46 & 0 & 1 & 546 \\
Children (Dummy) & 0.42 & 0.5 & 0 & 1 & 546 \\
Business Economics & 0.32 & 0.47 & 0 & 1 & 541 \\
Economics & 0.26 & 0.44 & 0 & 1 & 541 \\
Sociology/Social Sciences & 0.24 & 0.43 & 0 & 1 & 541 \\
Other Field & 0.18 & 0.38 & 0 & 1 & 541 \\
Assistant Professor & 0.09 & 0.29 & 0 & 1 & 546 \\
Research Assistant & 0.48 & 0.5 & 0 & 1 & 546 \\
Habilitand & 0.42 & 0.49 & 0 & 1 & 546 \\
Academic Lecturer & 0.14 & 0.35 & 0 & 1 & 546 \\
PhD Program (Dummy) & 0.12 & 0.33 & 0 & 1 & 546 \\
Years since completion of highest aca- & 10.8 & 5.65 & 1 & 44 & 546 \\
demic degree & & & & & \\
Years since completion of PhD & 5.6 & 5.04 & 1 & 36 & 534 \\
Conferences (national/international) & 0.84 & 0.36 & 0 & 1 & 546 \\
Research Stay & 0.29 & 0.45 & 0 & 1 & 546 \\
Referee Reports & 0.38 & 0.49 & 0 & 1 & 546 \\
Publication peer-reviewed journal & 0.58 & 0.49 & 0 & 1 & 546 \\
Third Party Funded Projects & 0.54 & 0.5 & 0 & 1 & 546 \\
\hline
\end{tabular}
$a$ : Number of respondents with valid answers for respective survey question. $b$ : Business Informatics, Industrial Engineering, others.

Table 2: Distribution of researcher types

\begin{tabular}{lll} 
Researcher Type & Absolute Frequency & Percent \\
\hline Frustrated pessimists & 146 & $33 \%$ \\
Motivated optimists & 142 & $32 \%$ \\
Confident academics & 159 & $36 \%$ \\
Total & 447 & $100 \%$ \\
\hline
\end{tabular}

Note: Result of a k-means cluster analysis with Jaccard similarity measure. 


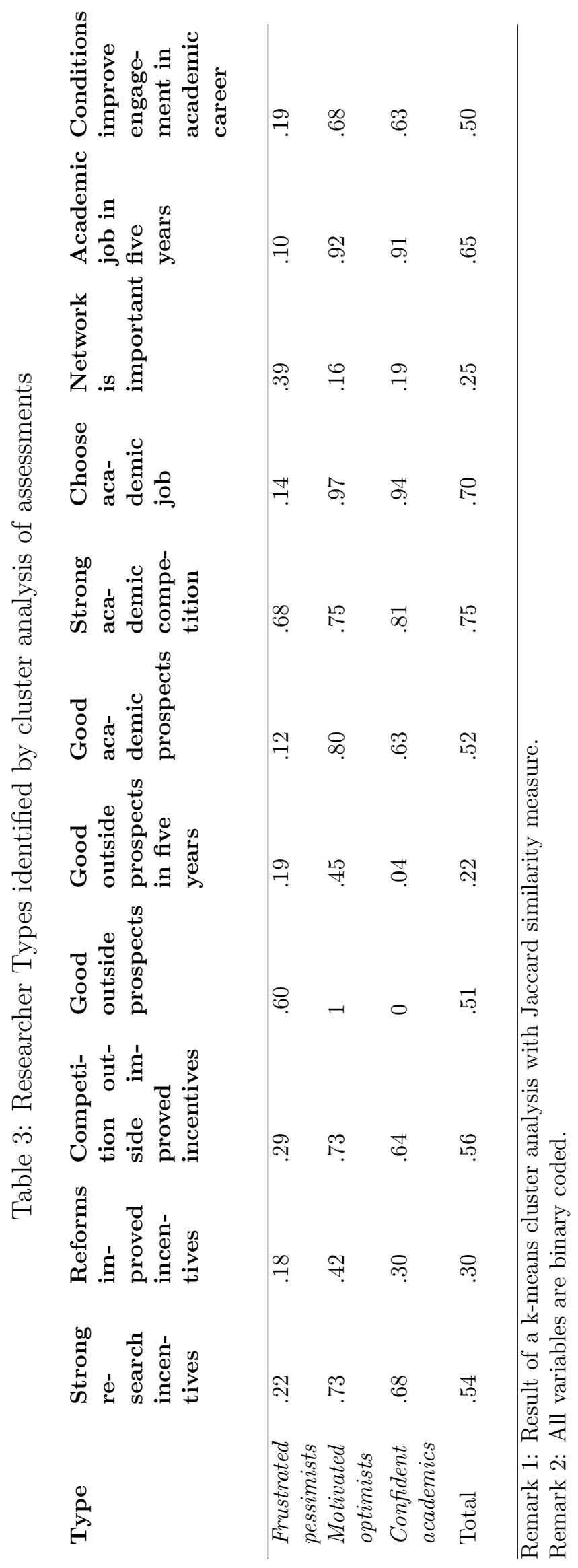


Table 4: Characterization of researcher types regarding background variables

\begin{tabular}{llll}
$\begin{array}{l}\text { Background } \\
\text { Variable }\end{array}$ & $\begin{array}{l}\text { Frustrated } \\
\text { pessimists }\end{array}$ & $\begin{array}{l}\text { Motivated } \\
\text { optimists }\end{array}$ & $\begin{array}{l}\text { Confident } \\
\text { academics }\end{array}$ \\
\hline Female & $33 \%$ & $25 \%$ & $36 \%$ \\
Below 37 years & $51 \%$ & $68 \%$ & $41 \%$ \\
$37-40$ years & $23 \%$ & $21 \%$ & $29 \%$ \\
Older than 40 years & $26 \%$ & $11 \%$ & $30 \%$ \\
Business Economics & $35 \%$ & $44 \%$ & $25 \%$ \\
Economics & $22 \%$ & $29 \%$ & $26 \%$ \\
Sociology, Social Sciences & $22 \%$ & $9 \%$ & $30 \%$ \\
Other Field ${ }^{a}$ & $21 \%$ & $18 \%$ & $19 \%$ \\
PhD program & $9 \%$ & $15 \%$ & $10 \%$ \\
PhD at the chair of a professor & $78 \%$ & $65 \%$ & $69 \%$ \\
Assistant professor & $1 \%$ & $11 \%$ & $14 \%$ \\
Research assistant & $59 \%$ & $37 \%$ & $48 \%$ \\
Habilitand & $25 \%$ & $59 \%$ & $48 \%$ \\
Academic lecturer & $11 \%$ & $16 \%$ & $16 \%$
\end{tabular}

$a$ : Business Informatics, Industrial Engineering, others. 
Table 5: Probit regression of research incentives on background and assessments Dependent variable: Research incentives are rather strong or very strong

\begin{tabular}{|c|c|c|c|c|c|c|}
\hline \multirow[b]{2}{*}{ Female } & \multicolumn{2}{|c|}{ (1) } & \multicolumn{2}{|c|}{$(2)$} & \multicolumn{2}{|c|}{ (3) } \\
\hline & 0.150 & $(0.124)$ & $0.220^{*}$ & $(0.133)$ & $0.285^{*}$ & $(0.146)$ \\
\hline Age & -0.0136 & $(0.0176)$ & -0.00746 & $(0.0182)$ & 0.0120 & $(0.0195)$ \\
\hline Partnership & -0.0599 & $(0.152)$ & -0.141 & $(0.159)$ & -0.0216 & $(0.175)$ \\
\hline Single & -0.0422 & $(0.181)$ & -0.120 & $(0.189)$ & 0.00474 & $(0.214)$ \\
\hline Other family status & -0.0319 & $(0.376)$ & -0.0699 & $(0.399)$ & 0.00375 & $(0.438)$ \\
\hline One child & -0.0463 & $(0.161)$ & -0.0330 & $(0.167)$ & -0.0303 & $(0.185)$ \\
\hline Two children & -0.133 & $(0.191)$ & -0.154 & $(0.201)$ & -0.126 & $(0.223)$ \\
\hline More children & 0.0971 & $(0.263)$ & 0.0999 & $(0.275)$ & 0.128 & $(0.302)$ \\
\hline German & -0.152 & $(0.217)$ & -0.205 & $(0.233)$ & -0.122 & $(0.251)$ \\
\hline Years since final degree & -0.0275 & $(0.0235)$ & -0.0112 & $(0.0241)$ & -0.00635 & $(0.0262)$ \\
\hline Master & -0.107 & $(0.274)$ & -0.164 & $(0.286)$ & -0.379 & $(0.308)$ \\
\hline Magister & 0.0647 & $(0.203)$ & 0.0625 & $(0.218)$ & -0.131 & $(0.244)$ \\
\hline Other academic degree & -0.0586 & $(0.223)$ & -0.0646 & $(0.236)$ & -0.218 & $(0.255)$ \\
\hline Years since graduation & 0.00176 & $(0.0244)$ & -0.0192 & $(0.0253)$ & -0.0435 & $(0.0281)$ \\
\hline PhD in Germany & $-0.581^{* *}$ & $(0.261)$ & -0.202 & $(0.300)$ & -0.0173 & $(0.324)$ \\
\hline Business Studies & $-0.345^{* *}$ & $(0.151)$ & -0.196 & $(0.168)$ & -0.0860 & $(0.187)$ \\
\hline Sociology, Social Sciences & -0.163 & $(0.183)$ & -0.0904 & $(0.197)$ & 0.0430 & $(0.219)$ \\
\hline Other subject & -0.197 & $(0.179)$ & -0.142 & $(0.191)$ & 0.0686 & $(0.211)$ \\
\hline Assistant Professor & & & $0.749^{* * *}$ & $(0.248)$ & $0.508^{*}$ & $(0.282)$ \\
\hline Research Assistant & & & 0.0550 & $(0.137)$ & 0.0121 & $(0.152)$ \\
\hline Status Habilitation & & & $0.299^{* *}$ & $(0.127)$ & 0.0869 & $(0.142)$ \\
\hline Lecturer, Admin, Officer & & & 0.185 & $(0.187)$ & 0.0644 & $(0.204)$ \\
\hline PhD program & & & $0.436^{*}$ & $(0.226)$ & $0.729^{* * *}$ & $(0.255)$ \\
\hline $\mathrm{PhD}$ research institution & & & 0.154 & $(0.246)$ & -0.0708 & $(0.274)$ \\
\hline External Phd scholarship & & & 0.112 & $(0.208)$ & 0.0268 & $(0.226)$ \\
\hline Other PhD & & & $0.703^{*}$ & $(0.377)$ & 0.594 & $(0.411)$ \\
\hline PhD current university & & & $-0.217^{*}$ & $(0.128)$ & $-0.299^{* *}$ & $(0.141)$ \\
\hline National conferences & & & -0.0781 & $(0.163)$ & $-0.596^{* * *}$ & $(0.191)$ \\
\hline International conferences & & & 0.179 & $(0.154)$ & 0.226 & $(0.173)$ \\
\hline German research institute & & & -0.212 & $(0.251)$ & -0.202 & $(0.275)$ \\
\hline Foreign research institute & & & 0.169 & $(0.144)$ & 0.198 & $(0.159)$ \\
\hline Referee reports & & & 0.112 & $(0.147)$ & 0.0635 & $(0.163)$ \\
\hline Publications & & & 0.0797 & $(0.136)$ & 0.0265 & $(0.151)$ \\
\hline Third-party project & & & 0.0721 & $(0.151)$ & 0.192 & $(0.166)$ \\
\hline Third-party project $\times$ fem & & & 0.363 & $(0.254)$ & $0.576^{* *}$ & $(0.283)$ \\
\hline Prospects outside, dummy & & & & & -0.109 & $(0.102)$ \\
\hline Prospects outside 5y, dummy & & & & & 0.0411 & $(0.0971)$ \\
\hline Prospects academia, dummy & & & & & $0.290^{* * *}$ & $(0.0953)$ \\
\hline Competition academia, dummy & & & & & $0.373^{* * *}$ & $(0.134)$ \\
\hline Networks & & & & & $-0.545^{* * *}$ & $(0.130)$ \\
\hline Conditions prospects, dummy & & & & & $0.498^{* * *}$ & $(0.0838)$ \\
\hline No. observations & 529 & & 529 & & 528 & \\
\hline
\end{tabular}

Standard errors in parentheses. ${ }^{*} p<0.1,{ }^{* *} p<0.05,{ }^{* * *} p<0.01$ 
Table 6: Average marginal effects for probit regressions of research incentives, reforms, and international competition

\begin{tabular}{|c|c|c|c|c|c|c|}
\hline \multirow{2}{*}{$\begin{array}{l}\text { Dependent } \\
\text { Variable } \\
\text { Female }\end{array}$} & \multicolumn{2}{|c|}{ Research Incentives } & \multicolumn{2}{|c|}{$\begin{array}{l}\text { Reforms improved } \\
\text { Incentives }^{a}\end{array}$} & \multicolumn{2}{|c|}{$\begin{array}{l}\text { Competition outside } \\
\text { improved Incentives }\end{array}$} \\
\hline & $0.0789^{* *}$ & $(0.0396)$ & 0.0578 & $(0.0430)$ & 0.00140 & $(0.0440)$ \\
\hline Age & 0.00379 & $(0.00547)$ & $-0.0145^{* *}$ & $(0.00683)$ & $-0.0149^{* *}$ & $(0.00716)$ \\
\hline Partnership & -0.0127 & $(0.0487)$ & 0.0305 & $(0.0473)$ & 0.0260 & $(0.0537)$ \\
\hline Single & -0.00562 & $(0.0597)$ & -0.0181 & $(0.0577)$ & 0.0820 & $(0.0651)$ \\
\hline Other family status & -0.0176 & $(0.122)$ & 0.0372 & $(0.116)$ & -0.158 & $(0.126)$ \\
\hline One child & -0.0161 & $(0.0515)$ & -0.0584 & $(0.0520)$ & 0.0526 & $(0.0560)$ \\
\hline Two children & -0.0433 & $(0.0620)$ & -0.0184 & $(0.0626)$ & 0.0473 & $(0.0670)$ \\
\hline More children & 0.0393 & $(0.0842)$ & $0.143^{*}$ & $(0.0806)$ & 0.0690 & $(0.0953)$ \\
\hline German & -0.0246 & $(0.0700)$ & 0.0879 & $(0.0729)$ & -0.0528 & $(0.0777)$ \\
\hline Years since final degree & -0.000846 & $(0.00736)$ & 0.000565 & $(0.00767)$ & 0.00397 & $(0.00985)$ \\
\hline Master & -0.106 & $(0.0860)$ & -0.0670 & $(0.0865)$ & 0.0156 & $(0.0939)$ \\
\hline Magister & -0.0386 & $(0.0678)$ & -0.121 & $(0.0770)$ & 0.0360 & $(0.0737)$ \\
\hline Other academic degree & -0.0745 & $(0.0708)$ & $0.126^{*}$ & $(0.0729)$ & $0.175^{* *}$ & $(0.0849)$ \\
\hline Years since graduation & $-0.0147^{*}$ & $(0.00776)$ & 0.00370 & $(0.00781)$ & 0.0114 & $(0.00959)$ \\
\hline $\mathrm{PhD}$ in $\mathrm{G}$ & -0.00743 & $(0.0906)$ & 0.108 & $(0.0936)$ & $0.164^{*}$ & $(0.0912)$ \\
\hline Business Studies & -0.0199 & $(0.0522)$ & 0.0693 & $(0.0489)$ & $-0.0931^{*}$ & $(0.0565)$ \\
\hline Sociology, Social Sciences & 0.00912 & $(0.0610)$ & -0.0743 & $(0.0619)$ & $-0.317^{* * *}$ & $(0.0621)$ \\
\hline Other subject & 0.0173 & $(0.0589)$ & 0.0218 & $(0.0570)$ & $-0.236^{* * *}$ & $(0.0609)$ \\
\hline Assistant Professor & $0.147^{*}$ & $(0.0783)$ & $0.201^{* * *}$ & $(0.0693)$ & 0.0230 & $(0.0817)$ \\
\hline Research Assistant & -0.00252 & $(0.0425)$ & -0.0367 & $(0.0432)$ & -0.0327 & $(0.0463)$ \\
\hline Status Habilitation & 0.0265 & $(0.0395)$ & $-0.106^{* * *}$ & $(0.0401)$ & $0.101^{* *}$ & $(0.0430)$ \\
\hline Lecturer, Admin, Officer & 0.00972 & $(0.0568)$ & -0.0165 & $(0.0547)$ & 0.0722 & $(0.0640)$ \\
\hline $\mathrm{PhD}$ program & $0.222^{* * *}$ & $(0.0695)$ & 0.0357 & $(0.0677)$ & $0.147^{* *}$ & $(0.0752)$ \\
\hline $\mathrm{PhD}$ research institution & -0.00597 & $(0.0758)$ & -0.103 & $(0.0779)$ & 0.0139 & $(0.0792)$ \\
\hline External PhD scholarship & 0.00460 & $(0.0629)$ & -0.0227 & $(0.0675)$ & 0.0133 & $(0.0702)$ \\
\hline Other PhD & $0.197^{*}$ & $(0.114)$ & 0.157 & $(0.105)$ & -0.0411 & $(0.117)$ \\
\hline PhD current $\mathrm{u}$ & $-0.0888^{* *}$ & $(0.0389)$ & -0.0185 & $(0.0388)$ & $-0.0876^{* *}$ & $(0.0439)$ \\
\hline National conferences & $-0.168^{* * *}$ & $(0.0518)$ & -0.0375 & $(0.0501)$ & -0.0713 & $(0.0560)$ \\
\hline International conferences & 0.0624 & $(0.0479)$ & 0.0116 & $(0.0484)$ & -0.0455 & $(0.0532)$ \\
\hline German research institute & -0.0527 & $(0.0771)$ & -0.0640 & $(0.0784)$ & -0.0437 & $(0.0867)$ \\
\hline Foreign research institute & 0.0556 & $(0.0443)$ & 0.00475 & $(0.0428)$ & $0.0813^{*}$ & $(0.0478)$ \\
\hline Referee reports & 0.0209 & $(0.0456)$ & 0.0504 & $(0.0445)$ & $0.0856^{*}$ & $(0.0491)$ \\
\hline Publications & 0.0109 & $(0.0420)$ & -0.0156 & $(0.0412)$ & 0.0326 & $(0.0458)$ \\
\hline Third-party project & $0.106^{* * *}$ & $(0.0393)$ & 0.0178 & $(0.0382)$ & -0.0431 & $(0.0437)$ \\
\hline Prospects outside & -0.0365 & $(0.0282)$ & -0.0185 & $(0.0278)$ & -0.0316 & $(0.0310)$ \\
\hline Prospects outside $5 y$ & 0.0161 & $(0.0270)$ & 0.0328 & $(0.0260)$ & 0.0127 & $(0.0296)$ \\
\hline Prospects academia & $0.0813^{* * *}$ & $(0.0259)$ & 0.0263 & $(0.0276)$ & $0.0641^{* *}$ & $(0.0294)$ \\
\hline Competition academia & $0.100^{* * *}$ & $(0.0363)$ & 0.0440 & $(0.0365)$ & $0.0731^{*}$ & $(0.0383)$ \\
\hline Networks & $-0.155^{* * *}$ & $(0.0345)$ & $-0.147^{* * *}$ & $(0.0339)$ & $-0.0630^{*}$ & $(0.0377)$ \\
\hline Conditions prospects & $0.143^{* * *}$ & $(0.0210)$ & $0.0696^{* * *}$ & $(0.0234)$ & $0.0581^{* *}$ & $(0.0255)$ \\
\hline No. observations & 528 & & 503 & & 717 & \\
\hline
\end{tabular}

Standard errors in parentheses. ${ }^{*} p<0.1,{ }^{* *} p<0.05,{ }^{* * *} p<0.01$

The results for research incentives are based on specification (3) in Table 5.

$a$ : Dependent Variable: Reforms improved or slightly improved incentives.

$b$ : Dependent Variable: International competition improved or slightly improved incentives. 
Table 7: Average marginal effects for probit regressions of career prospects

\begin{tabular}{|c|c|c|c|c|c|c|}
\hline \multirow{2}{*}{$\begin{array}{l}\text { Dependent } \\
\text { Variable }\end{array}$} & \multicolumn{2}{|c|}{$\begin{array}{c}\text { Good academic } \\
\text { Career Prospects }^{a}\end{array}$} & \multicolumn{2}{|c|}{$\begin{array}{l}\text { Good non-academic } \\
\text { Career Prospects }\end{array}$} & \multicolumn{2}{|c|}{$\begin{array}{c}\text { Good non-academic Career } \\
\text { Prospects in } 5 \text { years }^{c}\end{array}$} \\
\hline & 0.0476 & $(0.0388)$ & -0.0338 & $(0.0437)$ & -0.0237 & $(0.0361)$ \\
\hline Age & -0.00704 & $(0.00639)$ & $-0.0260^{* * *}$ & $(0.00689)$ & -0.00181 & $(0.00569)$ \\
\hline Partnership & $-0.105^{* *}$ & $(0.0486)$ & 0.00393 & $(0.0528)$ & -0.0607 & $(0.0462)$ \\
\hline Single & -0.0712 & $(0.0586)$ & 0.0109 & $(0.0641)$ & 0.00971 & $(0.0534)$ \\
\hline Other family status & -0.0619 & $(0.111)$ & 0.0419 & $(0.132)$ & 0.0713 & $(0.105)$ \\
\hline One child & $-0.123^{* *}$ & $(0.0503)$ & -0.0788 & $(0.0557)$ & -0.0395 & $(0.0491)$ \\
\hline Two children & $-0.181^{* * *}$ & $(0.0596)$ & -0.0650 & $(0.0669)$ & -0.0129 & $(0.0567)$ \\
\hline More children & $-0.250^{* * *}$ & $(0.0865)$ & 0.0588 & $(0.0922)$ & 0.0225 & $(0.0779)$ \\
\hline German & -0.0141 & $(0.0677)$ & $0.135^{*}$ & $(0.0749)$ & 0.0459 & $(0.0647)$ \\
\hline Years since final degree & -0.000406 & $(0.00759)$ & -0.00296 & $(0.00822)$ & -0.000183 & $(0.00703)$ \\
\hline Master & 0.0376 & $(0.0851)$ & $-0.171^{*}$ & $(0.0921)$ & $0.154^{* *}$ & $(0.0762)$ \\
\hline Magister & 0.0866 & $(0.0654)$ & -0.102 & $(0.0762)$ & -0.00272 & $(0.0693)$ \\
\hline Other academic degree & 0.0935 & $(0.0688)$ & 0.0356 & $(0.0777)$ & 0.0880 & $(0.0648)$ \\
\hline Years since graduation & 0.00258 & $(0.00779)$ & $0.0154^{*}$ & $(0.00831)$ & 0.00156 & $(0.00718)$ \\
\hline PhD in Germany & -0.128 & $(0.0846)$ & 0.0260 & $(0.0926)$ & 0.0984 & $(0.0843)$ \\
\hline Business Studies & 0.0613 & $(0.0510)$ & $0.0929^{*}$ & $(0.0541)$ & 0.0184 & $(0.0466)$ \\
\hline Sociology, Social Sciences & 0.00942 & $(0.0591)$ & $-0.144^{* *}$ & $(0.0646)$ & -0.0458 & $(0.0591)$ \\
\hline Other subject & -0.0360 & $(0.0572)$ & 0.0352 & $(0.0619)$ & -0.000133 & $(0.0541)$ \\
\hline Assistant Professor & $0.271^{* * *}$ & $(0.0752)$ & $-0.215^{* * *}$ & $(0.0782)$ & -0.0113 & $(0.0643)$ \\
\hline Research Assistant & -0.0402 & $(0.0412)$ & $-0.0930^{* *}$ & $(0.0459)$ & $-0.0984^{* *}$ & $(0.0387)$ \\
\hline Status Habilitation & $0.160^{* * *}$ & $(0.0367)$ & -0.0680 & $(0.0439)$ & -0.00434 & $(0.0379)$ \\
\hline Lecturer, Admin, Officer & -0.0707 & $(0.0558)$ & -0.0308 & $(0.0614)$ & $-0.0949^{*}$ & $(0.0519)$ \\
\hline PhD program & -0.0189 & $(0.0645)$ & $0.139^{*}$ & $(0.0712)$ & 0.00337 & $(0.0622)$ \\
\hline $\mathrm{PhD}$ research institution & 0.0343 & $(0.0726)$ & 0.0436 & $(0.0792)$ & -0.118 & $(0.0734)$ \\
\hline External PhD scholarship & 0.0218 & $(0.0644)$ & -0.0458 & $(0.0735)$ & -0.0620 & $(0.0667)$ \\
\hline Other PhD & 0.128 & $(0.107)$ & -0.0632 & $(0.119)$ & 0.0154 & $(0.0945)$ \\
\hline PhD current university & -0.0300 & $(0.0388)$ & 0.0179 & $(0.0429)$ & 0.0220 & $(0.0369)$ \\
\hline National conferences & $0.152^{* * *}$ & $(0.0486)$ & -0.0650 & $(0.0548)$ & -0.0466 & $(0.0472)$ \\
\hline International conferences & -0.0291 & $(0.0470)$ & $0.102^{*}$ & $(0.0524)$ & -0.00851 & $(0.0455)$ \\
\hline German research institute & $-0.158^{* *}$ & $(0.0752)$ & $-0.284^{* * *}$ & $(0.0867)$ & -0.135 & $(0.0855)$ \\
\hline Foreign research institute & 0.0596 & $(0.0429)$ & -0.0317 & $(0.0478)$ & -0.0413 & $(0.0415)$ \\
\hline Referee reports & $0.102^{* *}$ & $(0.0429)$ & -0.0267 & $(0.0490)$ & 0.0362 & $(0.0418)$ \\
\hline Publications & $0.101^{* * *}$ & $(0.0392)$ & 0.0470 & $(0.0448)$ & 0.0413 & $(0.0395)$ \\
\hline Third-party project & -0.0399 & $(0.0381)$ & $0.0736^{*}$ & $(0.0415)$ & 0.00598 & $(0.0358)$ \\
\hline Prospects outside & 0.0318 & $(0.0274)$ & - & & - & \\
\hline Prospects outside $5 y$ & -0.00799 & $(0.0262)$ & - & & - & \\
\hline Prospects academia & - & & 0.0135 & $(0.0296)$ & 0.0147 & $(0.0256)$ \\
\hline Competition academia & $-0.0638^{*}$ & $(0.0361)$ & -0.0378 & $(0.0393)$ & $-0.0632^{* *}$ & $(0.0317)$ \\
\hline Networks & $-0.124^{* * *}$ & $(0.0333)$ & 0.0281 & $(0.0375)$ & -0.0376 & $(0.0326)$ \\
\hline Conditions prospects & $0.145^{* * *}$ & $(0.0192)$ & 0.0335 & $(0.0251)$ & $0.0747^{* * *}$ & $(0.0220)$ \\
\hline No. observations & 528 & & 528 & & 528 & \\
\hline
\end{tabular}

Standard errors in parentheses. ${ }^{*} p<0.1,{ }^{* *} p<0.05,{ }^{* * *} p<0.01$

$a$ : Dependent Variable: academic career prospects rather good or very good.

$b$ : Dependent Variable: non-academic career prospects rather good or very good.

$c$ : Dependent Variable: non-academic career prospects in five years rather good or very good. 
Figure 1: Career path after $\mathrm{PhD}$

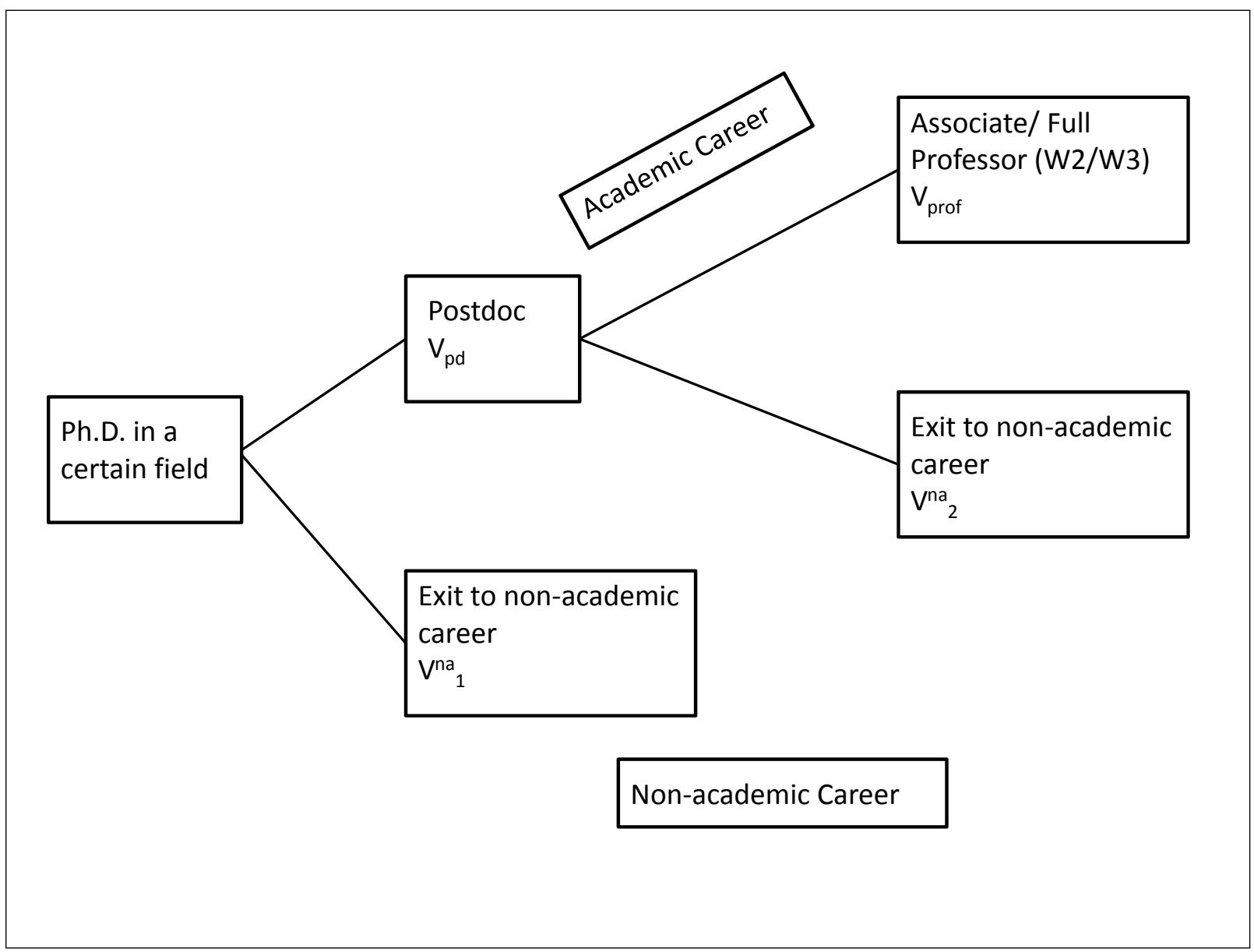

Note: This figure depicts in a stylized way the possible career transitions after obtaining a $\mathrm{PhD}$. The variable $V$ denotes the expected value (utility) after having reached a certain stage of the career. 
Figure 2: Assessments of research motivation and career prospects

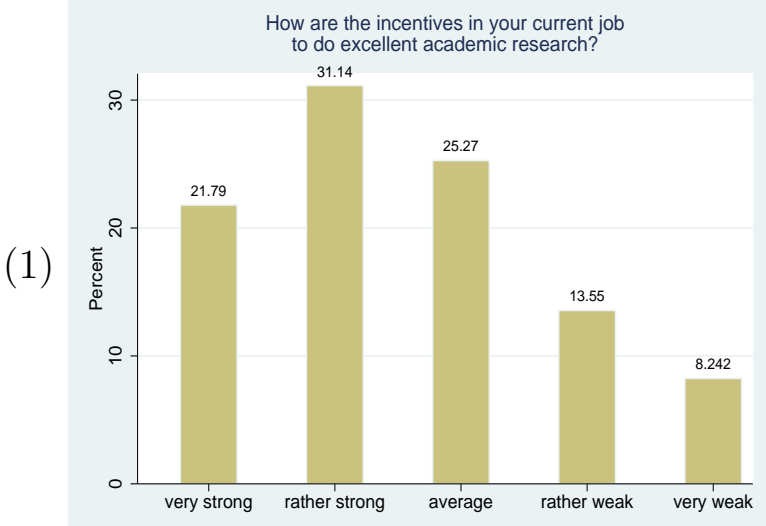

(2)
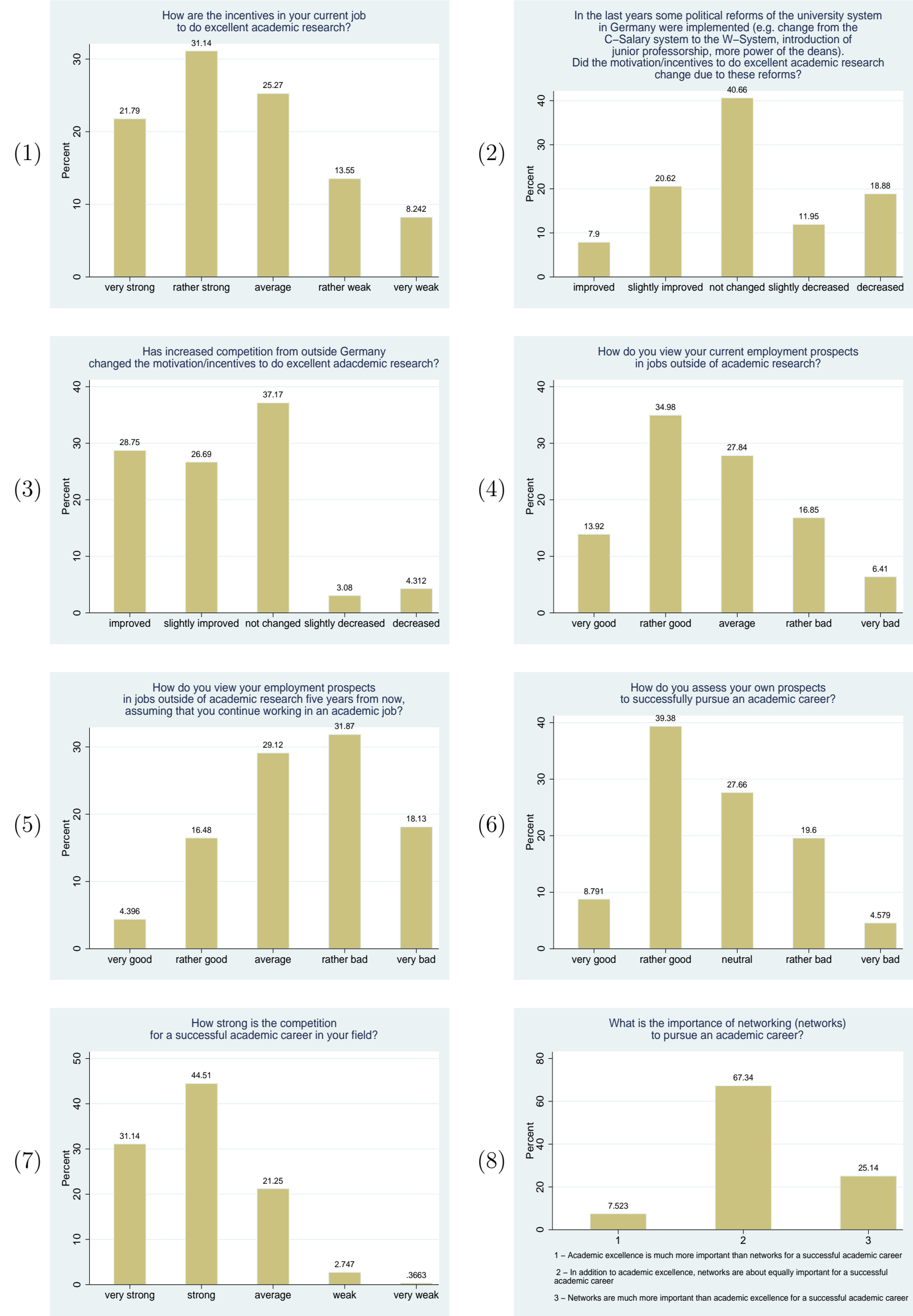
Figure 2: Assessments of research motivation and career prospects $<$ continued $>$

(9)
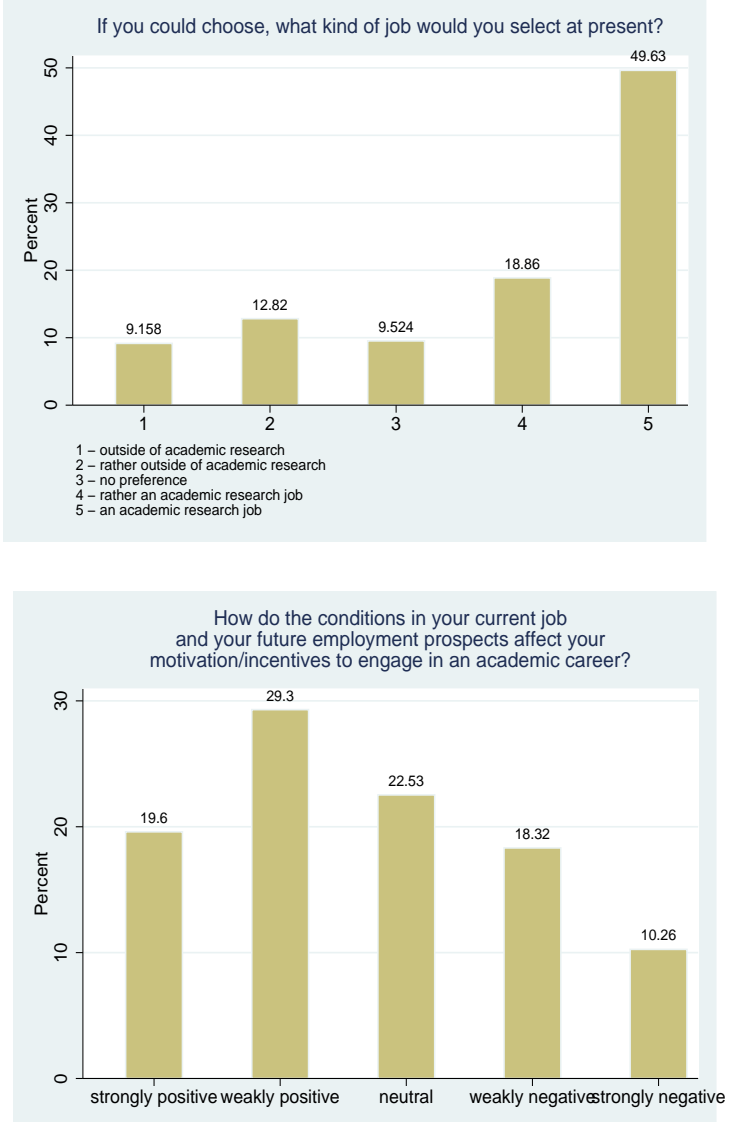

(13)

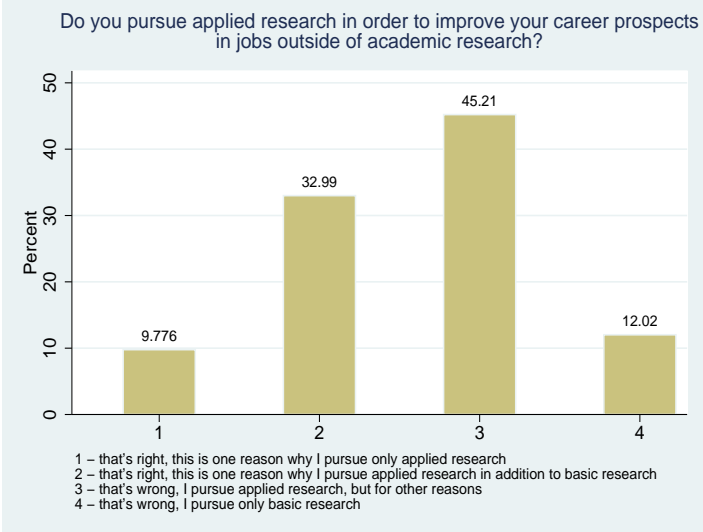

(10)

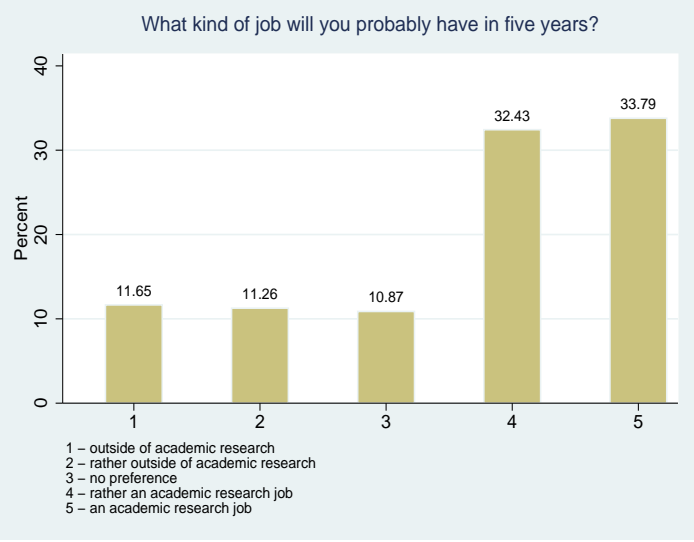

$(12)$

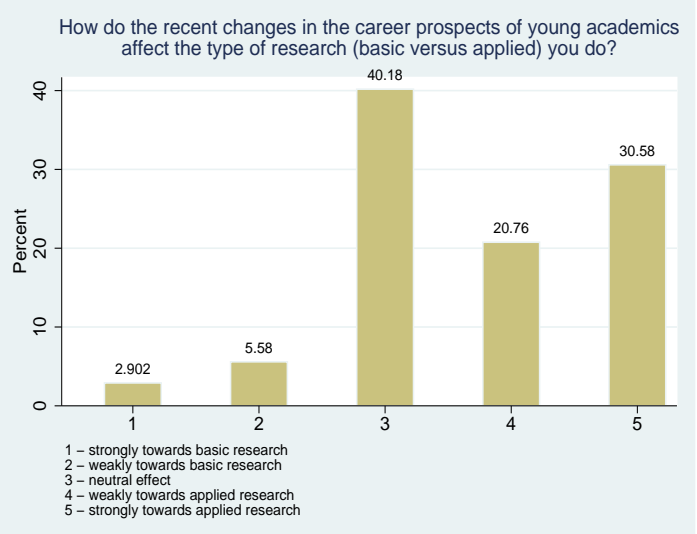




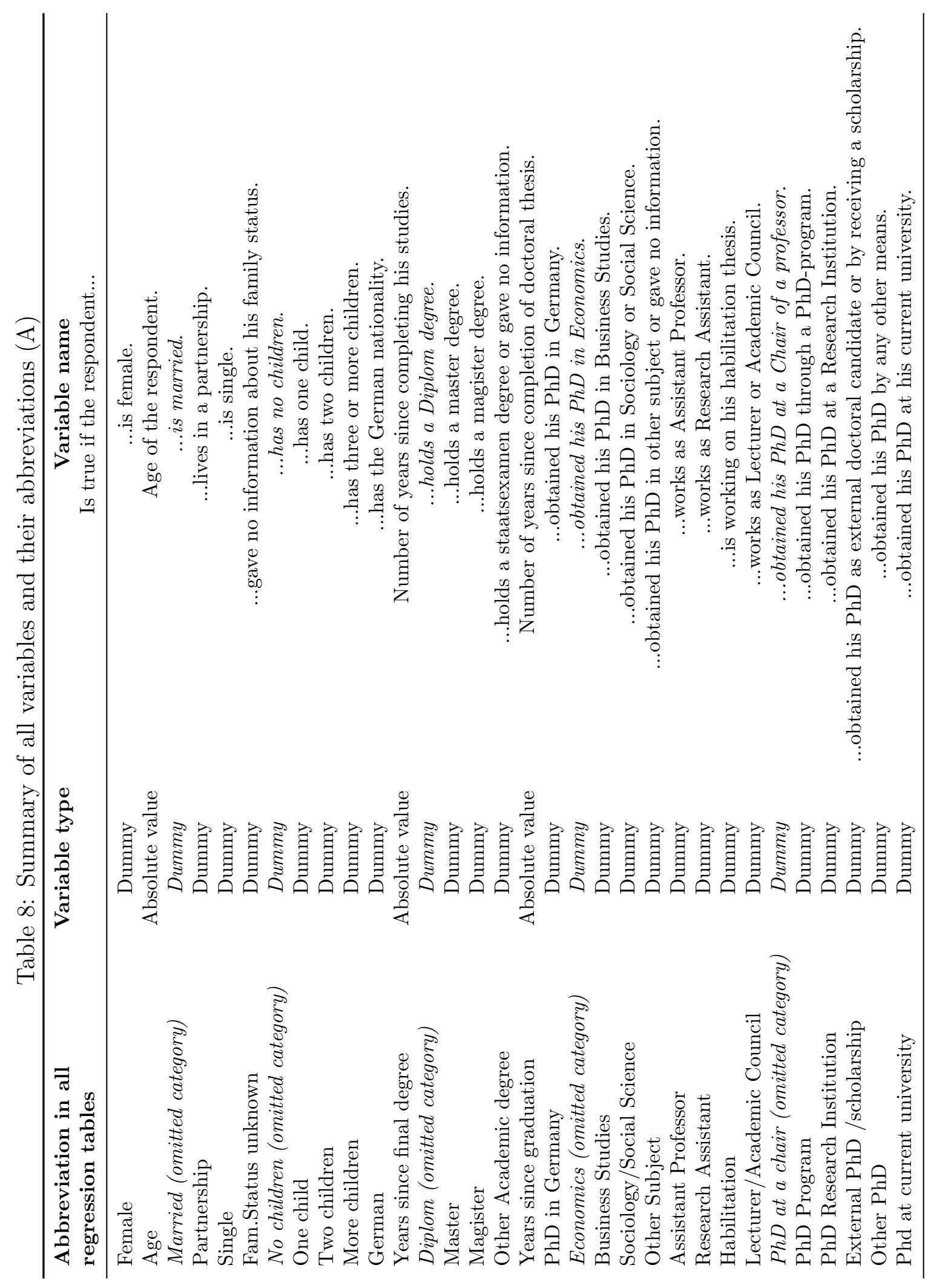


Table 9: Summary of all variables and their abbreviations (B)

\begin{tabular}{|c|c|c|}
\hline $\begin{array}{l}\text { Abbreviation in all } \\
\text { regression tables }\end{array}$ & Variable type & $\begin{array}{c}\text { Variable name } \\
\text { Dummy is equal to one if the respondent... }\end{array}$ \\
\hline National conferences & Dummy & ...attended national conferences. \\
\hline International conferences & Dummy & ...attended International conferences. \\
\hline German research institute & Dummy & $\begin{array}{l}\text {...spent time at another German research } \\
\text { institute/university to do research. }\end{array}$ \\
\hline Foreign research institute & Dummy & $\begin{array}{l}\text {...spent time at another foreign research } \\
\text { institute/university to do research. }\end{array}$ \\
\hline Referee reports & Dummy & ...wrote referee reports. \\
\hline Publications & Dummy & $\begin{array}{l}\text {...published in peer-reviewed journals or } \\
\text { in a similar publication forum. }\end{array}$ \\
\hline Third party funded project & Dummy & ...cooporated in academic third-party-funded projects. \\
\hline
\end{tabular}

\begin{tabular}{|c|c|c|}
\hline $\begin{array}{l}\text { Abbreviation in all } \\
\text { regression tables }\end{array}$ & Variable type & Question \\
\hline Prospects outside & Ordinally scaled & $\begin{array}{c}\text { "How do you view your current } \\
\text { employment prospects outside of academic research?" }\end{array}$ \\
\hline Prospects outside in $5 y$ & Ordinally scaled & $\begin{array}{l}\text { "How do you view your current } \\
\text { employment prospects outside of academic research } \\
\text { five years from now, assuming that you } \\
\text { continue working in an academics job?" }\end{array}$ \\
\hline Prospects in academia & Ordinally scaled & $\begin{array}{l}\text { "How do you assess your own prospects } \\
\text { to successfully pursue an academic career?" }\end{array}$ \\
\hline Competition in academia & Ordinally scaled & $\begin{array}{l}\text { "How strong is the competition for a } \\
\text { successful academic career in your field?" }\end{array}$ \\
\hline Networks & Ordinally scaled & $\begin{array}{l}\text { "What ist the importance of networking } \\
\text { (networks) to pursue an academic career?" }\end{array}$ \\
\hline Conditions and motivation & Ordinally scaled & $\begin{array}{l}\text { "How do the conditions in your current job } \\
\text { and your future employment prospects affect your } \\
\text { motivation/incentives to engage in an academic career?" }\end{array}$ \\
\hline
\end{tabular}

Abbrevation, dummy

Abbrevation $\times$ fem
Dummy

Interaction term
Original Variable recoded as binary variable.

Interaction effect with gender (female dummy). 


\section{Additional Appendix for the paper \\ 'Career Prospects of Postdocs in Germany'}

By Bernd Fitzenberger and Ute Leuschner

\section{Tables}

Table 1: Age distribution of the postdocs in classes and sex ratio

\begin{tabular}{lllllll} 
Classes & Women $(\mathbf{n})$ & Women & Men $(\mathbf{n})$ & Men & All (n) & All \\
\hline Below 33 years & 20 & $11 \%$ & 58 & $16 \%$ & 78 & $14 \%$ \\
$33-36$ years & 62 & $33 \%$ & 137 & $38 \%$ & 199 & $37 \%$ \\
$37-40$ years & 44 & $24 \%$ & 88 & $24 \%$ & 132 & $24 \%$ \\
41-44 years & 33 & $18 \%$ & 45 & $13 \%$ & 78 & $15 \%$ \\
Older than 44 & 27 & $14 \%$ & 32 & $9 \%$ & 59 & $11 \%$ \\
Sex ratio & 186 & $34 \%$ & 360 & $66 \%$ & 546 & $100 \%$
\end{tabular}

Table 2: Partnership status and children by sex

\begin{tabular}{|c|c|c|c|c|c|c|}
\hline Status & Women (n) & Women & Men (n) & Men & All (n) & All \\
\hline Married & 85 & $46 \%$ & 173 & $48 \%$ & 258 & $47 \%$ \\
\hline Partnership & 50 & $27 \%$ & 120 & $32 \%$ & 170 & $31 \%$ \\
\hline Single & 46 & $25 \%$ & 56 & $16 \%$ & 102 & $19 \%$ \\
\hline No answer & 5 & $2 \%$ & 11 & $3 \%$ & 16 & $3 \%$ \\
\hline \multicolumn{7}{|l|}{ Children } \\
\hline No children & 103 & $55 \%$ & 212 & $59 \%$ & 315 & $58 \%$ \\
\hline One child & 46 & $25 \%$ & 70 & $19 \%$ & 116 & $21 \%$ \\
\hline Two children & 30 & $16 \%$ & 52 & $15 \%$ & 82 & $15 \%$ \\
\hline $\begin{array}{l}\text { Three or more } \\
\text { children }\end{array}$ & 7 & $4 \%$ & 26 & $7 \%$ & 33 & $6 \%$ \\
\hline
\end{tabular}

Table 3: Subject of the highest academic degree and of the $\mathrm{PhD}$

Subject Highest Academic Degree (before PhD)

Subject $\mathrm{PhD}$

\begin{tabular}{lllllll} 
Subject & Women & Men & All & Women & Men & All \\
\hline Business Economics & $24 \%$ & $33 \%$ & $30 \%$ & $27 \%$ & $35 \%$ & $32 \%$ \\
Economics & $19 \%$ & $23 \%$ & $22 \%$ & $25 \%$ & $26 \%$ & $26 \%$ \\
Sociology, & $28 \%$ & $18 \%$ & $19 \%$ & $33 \%$ & $20 \%$ & $24 \%$ \\
$\begin{array}{l}\text { Social Sciences } \\
\text { Business Informatics, }\end{array}$ & $34 \%$ & $26 \%$ & $29 \%$ & $15 \%$ & $19 \%$ & $18 \%$ \\
Ind. Engineering, & & & & & &
\end{tabular}

Other 
Table 4: Current employment status (multiple answers possible)

\begin{tabular}{lllllll} 
Status & Women (n) & Women & Men (n) & Men & All (n) & All \\
\hline $\begin{array}{l}\text { Assistant professor } \\
\text { (Juniorprofessor/in) }\end{array}$ & 19 & $10 \%$ & 30 & $8 \%$ & 49 & $9 \%$ \\
$\begin{array}{l}\text { Research assistant } \\
\text { Habilitand }\end{array}$ & 95 & $51 \%$ & 168 & $47 \%$ & 263 & $48 \%$ \\
Academic lecturer & 18 & $31 \%$ & 170 & $47 \%$ & 228 & $42 \%$ \\
$\begin{array}{l}\text { Do not work any- } \\
\text { more in academia }\end{array}$ & 9 & $10 \%$ & 59 & $16 \%$ & 77 & $14 \%$ \\
$\begin{array}{l}\text { Other } \\
\text { ather }\end{array}$ & 52 & $17 \%$ & 40 & $11 \%$ & 72 & $13 \%$
\end{tabular}

Table 5: Highest academic degree before $\mathrm{PhD}$

\begin{tabular}{llll} 
Degree & Women & Men & All \\
\hline Master & $9 \%$ & $6 \%$ & $7 \%$ \\
Magister & $14 \%$ & $10 \%$ & $11 \%$ \\
Diplom & $65 \%$ & $78 \%$ & $74 \%$ \\
No answer & $12 \%$ & $6 \%$ & $8 \%$
\end{tabular}

Table 6: Did you obtain your $\mathrm{PhD}$ through a $\mathrm{PhD}$ programm (e.g. Graduiertenkolleg, PhD-Programm, Graduiertenschule)?

\begin{tabular}{lllllll} 
Item & Females (n) & Females & Men (n) & Men & All (n) & All \\
\hline Yes & 19 & $10 \%$ & 48 & $13 \%$ & 67 & $12 \%$ \\
$\begin{array}{l}\text { No, I did my PhD at the } \\
\text { chair of a professor }\end{array}$ & 123 & $66 \%$ & 250 & $70 \%$ & 373 & $68 \%$ \\
$\begin{array}{l}\text { No, I did my PhD at a re- } \\
\text { search institution }\end{array}$ & 16 & $9 \%$ & 21 & $6 \%$ & 37 & $7 \%$ \\
$\begin{array}{l}\text { External doctoral candi- } \\
\text { date, non academic job or }\end{array}$ & 20 & $11 \%$ & 30 & $8 \%$ & 50 & $9 \%$ \\
$\begin{array}{l}\text { scholarship } \\
\text { Other/No answer }\end{array}$ & 8 & $4 \%$ & 11 & $3 \%$ & 19 & $4 \%$
\end{tabular}


Table 7: Years since completion of highest academic degree before $\mathrm{PhD}$

\begin{tabular}{lllllll} 
Classes & Females (n) & Females & Males (n) & Males & All (n) & All \\
\hline 5 years and less & 14 & $8 \%$ & 35 & $10 \%$ & 49 & $9 \%$ \\
6-9 years & 75 & $40 \%$ & 150 & $42 \%$ & 225 & $41 \%$ \\
10-13 years & 49 & $26 \%$ & 121 & $33 \%$ & 170 & $31 \%$ \\
14-17 years & 27 & $15 \%$ & 27 & $7 \%$ & 54 & $10 \%$ \\
$\begin{array}{l}\text { 18-21 years } \\
\text { More than } 21\end{array}$ & 12 & $6 \%$ & 10 & $3 \%$ & 22 & $4 \%$ \\
years & & $5 \%$ & 17 & $5 \%$ & 26 & $5 \%$
\end{tabular}

Table 8: Years since completion of $\mathrm{PhD}$

\begin{tabular}{|c|c|c|c|c|c|c|c|}
\hline Classes & & Females (n) & Females & Males (n) & Males & All (n) & All \\
\hline $1-2$ years & & 41 & $22 \%$ & 92 & $26 \%$ & 133 & $24 \%$ \\
\hline $3-4$ years & & 47 & $25 \%$ & 99 & $28 \%$ & 146 & $27 \%$ \\
\hline $5-6$ years & & 33 & $18 \%$ & 76 & $21 \%$ & 109 & $20 \%$ \\
\hline 7-9 years & & 34 & $18 \%$ & 51 & $14 \%$ & 85 & $16 \%$ \\
\hline More than & 9 & 31 & $17 \%$ & 42 & $12 \%$ & 73 & $13 \%$ \\
\hline
\end{tabular}

Table 9: Years between highest academic degree and completion of $\mathrm{PhD}$

\begin{tabular}{|c|c|c|c|c|c|c|}
\hline Classes & Females (n) & Females & Males (n) & Males & All (n) & All \\
\hline Less than 2 years & 15 & $9 \%$ & 25 & $7 \%$ & 40 & $8 \%$ \\
\hline $2-3$ years & 15 & $8 \%$ & 35 & $10 \%$ & 50 & $9 \%$ \\
\hline 4 years & 32 & $18 \%$ & 75 & $21 \%$ & 107 & $20 \%$ \\
\hline 5 years & 34 & $19 \%$ & 67 & $19 \%$ & 101 & $19 \%$ \\
\hline 6 years & 29 & $16 \%$ & 72 & $21 \%$ & 101 & $19 \%$ \\
\hline 7-9 years & 43 & $24 \%$ & 62 & $18 \%$ & 105 & $20 \%$ \\
\hline More than 9 & 11 & $6 \%$ & 14 & $4 \%$ & 25 & $5 \%$ \\
\hline
\end{tabular}

years 
Table 10: Integration in the scientific community as $\mathrm{PhD}$ student (multiple answers possible)

\begin{tabular}{|c|c|c|c|c|c|c|}
\hline Item & Females (n) & Females & Males (n) & Males & All (n) & All \\
\hline National Conferences & 133 & $72 \%$ & 283 & $79 \%$ & 416 & $76 \%$ \\
\hline $\begin{array}{l}\text { International } \\
\text { Conferences }\end{array}$ & 117 & $63 \%$ & 242 & $67 \%$ & 359 & $66 \%$ \\
\hline $\begin{array}{l}\text { Research Stay at a } \\
\text { German institute/ } \\
\text { university }\end{array}$ & 10 & $5 \%$ & 21 & $6 \%$ & 31 & $6 \%$ \\
\hline $\begin{array}{l}\text { Research Stay at a } \\
\text { foreign institute/ } \\
\text { university }\end{array}$ & 59 & $32 \%$ & 82 & $23 \%$ & 141 & $26 \%$ \\
\hline Referee Reports & 51 & $27 \%$ & 158 & $44 \%$ & 209 & $38 \%$ \\
\hline $\begin{array}{l}\text { Publications in } \\
\text { peer-reviewed journals }\end{array}$ & 96 & $52 \%$ & 220 & $61 \%$ & 316 & $58 \%$ \\
\hline $\begin{array}{l}\text { Third party } \\
\text { funded projects }\end{array}$ & 96 & $52 \%$ & 200 & $56 \%$ & 296 & $54 \%$ \\
\hline No participation & 25 & $13 \%$ & 32 & $9 \%$ & 57 & $10 \%$ \\
\hline Other & 14 & $8 \%$ & 10 & $3 \%$ & 24 & $4 \%$ \\
\hline
\end{tabular}


Table 11: Agreement with statements by age

\begin{tabular}{|c|c|c|c|c|c|c|}
\hline Statement & $\begin{array}{l}32 \\
\text { years } \\
\text { and } \\
\text { younger }\end{array}$ & $\begin{array}{l}33-36 \\
\text { years }\end{array}$ & $\begin{array}{l}37-40 \\
\text { years }\end{array}$ & $\begin{array}{l}41-44 \\
\text { years }\end{array}$ & $\begin{array}{l}45 \\
\text { years } \\
\text { and } \\
\text { older }\end{array}$ & All \\
\hline $\begin{array}{l}\text { (1) The implementation of } \\
\text { junior-professorship has improved } \\
\text { the academic career prospects of } \\
\text { those who want to stay in academia. }\end{array}$ & $36 \%$ & $21 \%$ & $13 \%$ & $22 \%$ & $22 \%$ & $21 \%$ \\
\hline $\begin{array}{l}\text { (2) As a result of the moderate } \\
\text { salaries many established academics } \\
\text { leave German universities in order } \\
\text { to work at universities/research in- } \\
\text { stitutions abroad. }\end{array}$ & $51 \%$ & $47 \%$ & $36 \%$ & $44 \%$ & $27 \%$ & $42 \%$ \\
\hline $\begin{array}{l}\text { (3) As a result of the moder- } \\
\text { ate salaries many established aca- } \\
\text { demics leave German universities in } \\
\text { order to work outside of academic } \\
\text { research. }\end{array}$ & $40 \%$ & $25 \%$ & $24 \%$ & $31 \%$ & $34 \%$ & $28 \%$ \\
\hline $\begin{array}{l}\text { (4) As a result of the moderate } \\
\text { salaries many young academics leave } \\
\text { German universities in order to work } \\
\text { at universities/research institutions } \\
\text { abroad. }\end{array}$ & $60 \%$ & $61 \%$ & $46 \%$ & $50 \%$ & $32 \%$ & $52 \%$ \\
\hline $\begin{array}{l}\text { (5) As a result of the moderate } \\
\text { salaries many young academics leave } \\
\text { German universities in order to work } \\
\text { outside of academic research. }\end{array}$ & $63 \%$ & $56 \%$ & $46 \%$ & $45 \%$ & $36 \%$ & $51 \%$ \\
\hline $\begin{array}{l}\text { (6) As a result of the in- } \\
\text { secure working prospects (part- } \\
\text { time work, temporary employment), } \\
\text { many young academics leave Ger- } \\
\text { man universities. }\end{array}$ & $59 \%$ & $78 \%$ & $80 \%$ & $87 \%$ & $81 \%$ & $78 \%$ \\
\hline $\begin{array}{l}\text { (7) In comparison to a job outside } \\
\text { of academic research, an academic } \\
\text { research job is more risky. }\end{array}$ & $50 \%$ & $64 \%$ & $65 \%$ & $60 \%$ & $46 \%$ & $60 \%$ \\
\hline $\begin{array}{l}\text { (8) The introduction of Junior } \\
\text { Professorship is flawed because most } \\
\text { positions do not involve a tenure- } \\
\text { track option. }\end{array}$ & $55 \%$ & $66 \%$ & $60 \%$ & $63 \%$ & $51 \%$ & $61 \%$ \\
\hline
\end{tabular}


Table 12: Agreement with statements by fields

\begin{tabular}{|c|c|c|c|c|c|}
\hline Statement & $\begin{array}{l}\text { Business } \\
\text { Eco- } \\
\text { nomics }\end{array}$ & $\begin{array}{l}\text { Eco- } \\
\text { nomics }\end{array}$ & $\begin{array}{l}\text { Sociology, } \\
\text { Social } \\
\text { Sciences }\end{array}$ & $\begin{array}{l}\text { Business } \\
\text { Infor- } \\
\text { matics, } \\
\text { Industrial } \\
\text { Engineer- } \\
\text { ing, Others }\end{array}$ & All \\
\hline $\begin{array}{l}\text { (1) The implementation of } \\
\text { junior-professorship has improved } \\
\text { the academic career prospects of } \\
\text { those who want to stay in academia. }\end{array}$ & $23 \%$ & $21 \%$ & $24 \%$ & $17 \%$ & $21 \%$ \\
\hline $\begin{array}{l}\text { (2) As a result of the moderate } \\
\text { salaries many established academics } \\
\text { leave German universities in order } \\
\text { to work at universities/research in- } \\
\text { stitutions abroad. }\end{array}$ & $44 \%$ & $46 \%$ & $38 \%$ & $39 \%$ & $42 \%$ \\
\hline $\begin{array}{l}\text { (3) As a result of the moder- } \\
\text { ate salaries many established aca- } \\
\text { demics leave German universities in } \\
\text { order to work outside of academic } \\
\text { research. }\end{array}$ & $28 \%$ & $22 \%$ & $32 \%$ & $34 \%$ & $28 \%$ \\
\hline $\begin{array}{l}\text { (4) As a result of the moderate } \\
\text { salaries many young academics leave } \\
\text { German universities in order to work } \\
\text { at universities/research institutions } \\
\text { abroad. }\end{array}$ & $56 \%$ & $60 \%$ & $44 \%$ & $46 \%$ & $52 \%$ \\
\hline $\begin{array}{l}\text { (5) As a result of the moderate } \\
\text { salaries many young academics leave } \\
\text { German universities in order to work } \\
\text { outside of academic research. }\end{array}$ & $61 \%$ & $48 \%$ & $40 \%$ & $49 \%$ & $51 \%$ \\
\hline $\begin{array}{l}\text { (6) As a result of the in- } \\
\text { secure working prospects (part- } \\
\text { time work, temporary employment), } \\
\text { many young academics leave Ger- } \\
\text { man universities. }\end{array}$ & $73 \%$ & $78 \%$ & $85 \%$ & $67 \%$ & $78 \%$ \\
\hline $\begin{array}{l}\text { (7) In comparison to a job outside } \\
\text { of academic research, an academic } \\
\text { research job is more risky. }\end{array}$ & $59 \%$ & $63 \%$ & $58 \%$ & $62 \%$ & $60 \%$ \\
\hline $\begin{array}{l}\text { (8) The introduction of Junior } \\
\text { Professorships is flawed because } \\
\text { most positions do not involve a } \\
\text { tenure-track option. }\end{array}$ & $55 \%$ & $73 \%$ & $61 \%$ & $55 \%$ & $61 \%$ \\
\hline
\end{tabular}


Table 13: How are the incentives in your current job to do excellent academic research?

(1)

(2)

(3)

Incentives_research Incentives_research_bin Marginal Effects

\begin{tabular}{|c|c|c|c|c|c|c|}
\hline \multicolumn{7}{|l|}{ main } \\
\hline Women & 0.0986 & $(0.109)$ & $0.285^{*}$ & $(0.146)$ & $0.0789^{* *}$ & $(0.0396)$ \\
\hline Age & 0.00429 & $(0.0155)$ & 0.0120 & $(0.0195)$ & 0.00379 & $(0.00547)$ \\
\hline Partnership & 0.125 & $(0.132)$ & -0.0216 & $(0.175)$ & -0.0127 & $(0.0487)$ \\
\hline Single & -0.0973 & $(0.159)$ & 0.00474 & $(0.214)$ & -0.00562 & $(0.0597)$ \\
\hline Other18 & 0.352 & $(0.326)$ & 0.00375 & $(0.438)$ & -0.0176 & $(0.122)$ \\
\hline One_child & 0.00334 & $(0.139)$ & -0.0303 & $(0.185)$ & -0.0161 & $(0.0515)$ \\
\hline Two_children & -0.0718 & $(0.167)$ & -0.126 & $(0.223)$ & -0.0433 & $(0.0620)$ \\
\hline More_children & 0.255 & $(0.228)$ & 0.128 & $(0.302)$ & 0.0393 & $(0.0842)$ \\
\hline German & -0.0181 & $(0.188)$ & -0.122 & $(0.251)$ & -0.0246 & $(0.0700)$ \\
\hline Years_since_final_degree & -0.0132 & $(0.0200)$ & -0.00635 & $(0.0262)$ & -0.000846 & $(0.00736)$ \\
\hline Master & -0.220 & $(0.235)$ & -0.379 & $(0.308)$ & -0.106 & $(0.0860)$ \\
\hline Magister & 0.215 & $(0.185)$ & -0.131 & $(0.244)$ & -0.0386 & $(0.0678)$ \\
\hline Other23 & -0.123 & $(0.193)$ & -0.218 & $(0.255)$ & -0.0745 & $(0.0708)$ \\
\hline Years_since_graduation & -0.0182 & $(0.0210)$ & -0.0435 & $(0.0281)$ & $-0.0147^{*}$ & $(0.00776)$ \\
\hline PhD_in_Germany & 0.0667 & $(0.235)$ & -0.0173 & $(0.324)$ & -0.00743 & $(0.0906)$ \\
\hline Business_Studies & -0.158 & $(0.139)$ & -0.0860 & $(0.187)$ & -0.0199 & $(0.0522)$ \\
\hline Sociology_SocialScience & -0.0636 & $(0.161)$ & 0.0430 & $(0.219)$ & 0.00912 & $(0.0610)$ \\
\hline Other30 & 0.0390 & $(0.157)$ & 0.0686 & $(0.211)$ & 0.0173 & $(0.0589)$ \\
\hline Assistant_Professor & 0.283 & $(0.202)$ & $0.508^{*}$ & $(0.282)$ & $0.147^{*}$ & $(0.0783)$ \\
\hline Research_Assistant & 0.0931 & $(0.116)$ & 0.0121 & $(0.152)$ & -0.00252 & $(0.0425)$ \\
\hline Status_Habilitation & 0.0163 & $(0.109)$ & 0.0869 & $(0.142)$ & 0.0265 & $(0.0395)$ \\
\hline Lecturer_Admin_Officer & -0.0512 & $(0.155)$ & 0.0644 & $(0.204)$ & 0.00972 & $(0.0568)$ \\
\hline PhD_program & $0.344^{*}$ & $(0.182)$ & $0.729^{* * *}$ & $(0.255)$ & $0.222^{* * *}$ & $(0.0695)$ \\
\hline PhD_research_institution & 0.00434 & $(0.200)$ & -0.0708 & $(0.274)$ & -0.00597 & $(0.0758)$ \\
\hline ExternalPhd_scholarship & 0.101 & $(0.175)$ & 0.0268 & $(0.226)$ & 0.00460 & $(0.0629)$ \\
\hline Other27 & $0.583^{*}$ & $(0.298)$ & 0.594 & $(0.411)$ & $0.197^{*}$ & $(0.114)$ \\
\hline PhD_current_university & $-0.227^{* *}$ & $(0.107)$ & $-0.299^{* *}$ & $(0.141)$ & $-0.0888^{* *}$ & $(0.0389)$ \\
\hline National_conferences & $-0.476^{* * *}$ & $(0.140)$ & $-0.596^{* * *}$ & $(0.191)$ & $-0.168^{* * *}$ & $(0.0518)$ \\
\hline International_conferences & 0.111 & $(0.129)$ & 0.226 & $(0.173)$ & 0.0624 & $(0.0479)$ \\
\hline German_research_institute & -0.0410 & $(0.209)$ & -0.202 & $(0.275)$ & -0.0527 & $(0.0771)$ \\
\hline Foreign_research_institute & 0.103 & $(0.120)$ & 0.198 & $(0.159)$ & 0.0556 & $(0.0443)$ \\
\hline Referee_reports & 0.0106 & $(0.122)$ & 0.0635 & $(0.163)$ & 0.0209 & $(0.0456)$ \\
\hline Publications & 0.131 & $(0.112)$ & 0.0265 & $(0.151)$ & 0.0109 & $(0.0420)$ \\
\hline Third_party_funded_project & 0.0139 & $(0.124)$ & 0.192 & $(0.166)$ & $0.106^{* * *}$ & $(0.0393)$ \\
\hline Prospects_outside_cat & 0.0159 & $(0.0758)$ & -0.109 & $(0.102)$ & -0.0365 & $(0.0282)$ \\
\hline Prospects_outside_5y_cat & 0.0323 & $(0.0740)$ & 0.0411 & $(0.0971)$ & 0.0161 & $(0.0270)$ \\
\hline Prospects_academia_cat & $0.311^{* * *}$ & $(0.0733)$ & $0.290^{* * *}$ & $(0.0953)$ & $0.0813^{* * *}$ & $(0.0259)$ \\
\hline Competition_academia_cat & $0.440^{* * *}$ & $(0.0998)$ & $0.373^{* * *}$ & $(0.134)$ & $0.100^{* * *}$ & $(0.0363)$ \\
\hline Networks_n & $-0.456^{* * *}$ & $(0.0958)$ & $-0.545^{* * *}$ & $(0.130)$ & $-0.155^{* * *}$ & $(0.0345)$ \\
\hline Conditions_prospects_cat & $0.477^{* * *}$ & $(0.0649)$ & $0.498^{* * *}$ & $(0.0838)$ & $0.143^{* * *}$ & $(0.0210)$ \\
\hline Third_party_funded_projectI & $0.405^{*}$ & $(0.211)$ & $0.576^{* *}$ & $(0.283)$ & & \\
\hline$N$ & 528 & & 528 & & 528 & \\
\hline
\end{tabular}

Marginal effects; Standard errors in parentheses

Values of the dependent variable (categorial): $1=$ very weak, $2=$ rather weak

$3=$ average $4=$ rather strong, $5=$ very strong

Values of the dependent variable (binary): $1=$ rather strong + very strong, $0=$ other

(1): Ordered Probit, (2): Probit, (3): Marginal effects of Probit(2)

(d) for discrete change of dummy variable from 0 to 1

${ }^{*} p<0.1,{ }^{* *} p<0.05,{ }^{* * *} p<0.01$ 
Table 14: In the last years, some political reforms of the university system in Germany were implemented (e.g. change from C-salary system to the $\mathrm{W}$-system, introduction of junior professorship, more power of the deans). Did the motivation/incentives to do excellent academic research change due to these reforms?

\begin{tabular}{|c|c|c|c|c|c|c|}
\hline \multirow[b]{2}{*}{ main } & \multicolumn{2}{|c|}{$\begin{array}{c}(1) \\
\text { Incentives_due_reforms }\end{array}$} & \multicolumn{2}{|c|}{$\begin{array}{c}(2) \\
\text { Incentives_due_reforms_bin }\end{array}$} & \multicolumn{2}{|c|}{$\begin{array}{c}(3) \\
\text { Marginal effects }\end{array}$} \\
\hline & & & & & & \\
\hline Women & 0.143 & $(0.113)$ & 0.124 & $(0.168)$ & 0.0578 & $(0.0430)$ \\
\hline Age & -0.0286 & $(0.0175)$ & $-0.0505^{*}$ & $(0.0273)$ & $-0.0145^{* *}$ & $(0.00683)$ \\
\hline Partnership & $0.233^{*}$ & $(0.136)$ & 0.205 & $(0.189)$ & 0.0305 & $(0.0473)$ \\
\hline Single & 0.0967 & $(0.162)$ & 0.00850 & $(0.228)$ & -0.0181 & $(0.0577)$ \\
\hline Other 18 & 0.351 & $(0.330)$ & 0.269 & $(0.455)$ & 0.0372 & $(0.116)$ \\
\hline One_child & -0.122 & $(0.145)$ & -0.153 & $(0.206)$ & -0.0584 & $(0.0520)$ \\
\hline Two_children & 0.0770 & $(0.171)$ & -0.0538 & $(0.248)$ & -0.0184 & $(0.0626)$ \\
\hline More_children & $0.390^{*}$ & $(0.233)$ & 0.509 & $(0.316)$ & $0.143^{*}$ & $(0.0806)$ \\
\hline German & -0.0348 & $(0.196)$ & 0.360 & $(0.288)$ & 0.0879 & $(0.0729)$ \\
\hline Years_since_final_degree & -0.0106 & $(0.0211)$ & 0.00922 & $(0.0305)$ & 0.000565 & $(0.00767)$ \\
\hline Master & 0.206 & $(0.247)$ & -0.220 & $(0.341)$ & -0.0670 & $(0.0865)$ \\
\hline Magister & -0.0981 & $(0.188)$ & $-0.529^{*}$ & $(0.312)$ & -0.121 & $(0.0770)$ \\
\hline Other23 & 0.0776 & $(0.211)$ & 0.388 & $(0.290)$ & $0.126^{*}$ & $(0.0729)$ \\
\hline Years_since_graduation & 0.0255 & $(0.0220)$ & 0.000974 & $(0.0314)$ & 0.00370 & $(0.00781)$ \\
\hline PhD_in_Germany & $0.492^{*}$ & $(0.254)$ & 0.348 & $(0.371)$ & 0.108 & $(0.0936)$ \\
\hline Business_Studies & 0.117 & $(0.142)$ & 0.263 & $(0.192)$ & 0.0693 & $(0.0489)$ \\
\hline Sociology_SocialScience & -0.122 & $(0.201)$ & 0.0273 & $(0.294)$ & -0.0743 & $(0.0619)$ \\
\hline Other30 & -0.0305 & $(0.183)$ & 0.403 & $(0.251)$ & 0.0218 & $(0.0570)$ \\
\hline Assistant_Professor & $0.679^{* * *}$ & $(0.209)$ & $0.765^{* * *}$ & $(0.277)$ & $0.201^{* * *}$ & $(0.0693)$ \\
\hline Research_Assistant & -0.107 & $(0.120)$ & -0.180 & $(0.170)$ & -0.0367 & $(0.0432)$ \\
\hline Status_Habilitation & -0.156 & $(0.112)$ & $-0.396^{* *}$ & $(0.159)$ & $-0.106^{* * *}$ & $(0.0401)$ \\
\hline Lecturer_Admin_Officer & -0.0229 & $(0.156)$ & -0.107 & $(0.214)$ & -0.0165 & $(0.0547)$ \\
\hline PhD_program & 0.144 & $(0.187)$ & 0.0615 & $(0.267)$ & 0.0357 & $(0.0677)$ \\
\hline PhD_research_institution & 0.00747 & $(0.211)$ & -0.359 & $(0.305)$ & -0.103 & $(0.0779)$ \\
\hline ExternalPhd_scholarship & -0.254 & $(0.218)$ & -0.426 & $(0.329)$ & -0.0227 & $(0.0675)$ \\
\hline Other27 & $0.552^{*}$ & $(0.299)$ & 0.536 & $(0.415)$ & 0.157 & $(0.105)$ \\
\hline PhD_current_university & -0.0553 & $(0.109)$ & -0.0959 & $(0.152)$ & -0.0185 & $(0.0388)$ \\
\hline National_conferences & -0.201 & $(0.141)$ & -0.154 & $(0.196)$ & -0.0375 & $(0.0501)$ \\
\hline International_conferences & 0.0373 & $(0.135)$ & 0.00799 & $(0.190)$ & 0.0116 & $(0.0484)$ \\
\hline German_research_institute & -0.130 & $(0.217)$ & -0.150 & $(0.306)$ & -0.0640 & $(0.0784)$ \\
\hline Foreign_research_institute & 0.0669 & $(0.121)$ & 0.00334 & $(0.169)$ & 0.00475 & $(0.0428)$ \\
\hline Referee_reports & -0.0395 & $(0.126)$ & 0.165 & $(0.174)$ & 0.0504 & $(0.0445)$ \\
\hline Publications & -0.0231 & $(0.115)$ & -0.0553 & $(0.161)$ & -0.0156 & $(0.0412)$ \\
\hline Third_party_funded_project & 0.0874 & $(0.108)$ & 0.0394 & $(0.150)$ & 0.0178 & $(0.0382)$ \\
\hline Prospects_outside_cat & 0.00696 & $(0.0781)$ & -0.0594 & $(0.109)$ & -0.0185 & $(0.0278)$ \\
\hline Prospects_outside_5y_cat & 0.0875 & $(0.0754)$ & 0.129 & $(0.101)$ & 0.0328 & $(0.0260)$ \\
\hline Prospects_academia_cat & 0.0972 & $(0.0760)$ & 0.133 & $(0.108)$ & 0.0263 & $(0.0276)$ \\
\hline Competition_academia_cat & 0.0671 & $(0.102)$ & 0.177 & $(0.144)$ & 0.0440 & $(0.0365)$ \\
\hline Networks_n & $-0.448^{* * *}$ & $(0.0968)$ & $-0.569^{* * *}$ & $(0.139)$ & $-0.147^{* * *}$ & $(0.0339)$ \\
\hline Conditions_prospects_cat & $0.262^{* * *}$ & $(0.0662)$ & $0.243^{* * *}$ & $(0.0929)$ & $0.0696^{* * *}$ & $(0.0234)$ \\
\hline Sociology_SocialScienceI & $-0.574^{* *}$ & $(0.262)$ & $-0.785^{*}$ & $(0.402)$ & & \\
\hline Other30I & -0.432 & $(0.301)$ & $-1.216^{* *}$ & $(0.473)$ & & \\
\hline ExternalPhd_scholarshipI & 0.354 & $(0.373)$ & $1.155^{* *}$ & $(0.559)$ & & \\
\hline$N$ & 503 & & 503 & & 503 & \\
\hline
\end{tabular}

Marginal effects; Standard errors in parentheses

Values of the dependent variable (categorial): $1=$ decreased

$2=$ slightly decreased, $3=$ not changed, $4=$ slightly improved, $5=$ improved

Values of the dependent variable (binary): $1=$ slightly improved + improved, $0=$ other

(1): Ordered Probit, (2): Probit, (3): Marginal effects of Probit(2)

(d) for discrete change of dummy variable from 0 to 1

${ }^{*} p<0.1,{ }^{* *} p<0.05,{ }^{* * *} p<0.01$ 
Table 15: Has increased competition from outside Germany changed the motivation/incentives to do excellent academic research?

\begin{tabular}{|c|c|c|c|c|c|c|}
\hline \multirow{2}{*}{ main } & \multicolumn{2}{|c|}{$\begin{array}{c}(1) \\
\text { Competition_outside }\end{array}$} & \multicolumn{2}{|c|}{$\begin{array}{c}(2) \\
\text { Competition_outside_bin }\end{array}$} & \multicolumn{2}{|c|}{$\begin{array}{c}(3) \\
\text { Marginal effects }\end{array}$} \\
\hline & & & & & & \\
\hline Women & -0.0134 & $(0.118)$ & 0.00458 & $(0.149)$ & 0.00140 & $(0.0440)$ \\
\hline Age & $-0.0364^{* *}$ & $(0.0175)$ & $-0.0487^{* *}$ & $(0.0245)$ & $-0.0149^{* *}$ & $(0.00716)$ \\
\hline Partnership & 0.158 & $(0.143)$ & 0.0851 & $(0.182)$ & 0.0260 & $(0.0537)$ \\
\hline Single & $0.291^{*}$ & $(0.172)$ & 0.269 & $(0.222)$ & 0.0820 & $(0.0651)$ \\
\hline Other18 & -0.403 & $(0.361)$ & -0.517 & $(0.429)$ & -0.158 & $(0.126)$ \\
\hline One_child & 0.114 & $(0.151)$ & 0.173 & $(0.190)$ & 0.0526 & $(0.0560)$ \\
\hline Two_children & 0.115 & $(0.181)$ & 0.155 & $(0.227)$ & 0.0473 & $(0.0670)$ \\
\hline More_children & 0.359 & $(0.262)$ & 0.226 & $(0.323)$ & 0.0690 & $(0.0953)$ \\
\hline German & -0.0244 & $(0.206)$ & -0.173 & $(0.264)$ & -0.0528 & $(0.0777)$ \\
\hline Years_since_final_degree & -0.0124 & $(0.0255)$ & 0.0130 & $(0.0334)$ & 0.00397 & $(0.00985)$ \\
\hline Master & 0.0703 & $(0.254)$ & 0.0512 & $(0.318)$ & 0.0156 & $(0.0939)$ \\
\hline Magister & $0.362^{*}$ & $(0.198)$ & 0.118 & $(0.250)$ & 0.0360 & $(0.0737)$ \\
\hline Other23 & $0.500^{* *}$ & $(0.227)$ & $0.573^{* *}$ & $(0.292)$ & $0.175^{* *}$ & $(0.0849)$ \\
\hline Years_since_graduation & $0.0487^{*}$ & $(0.0256)$ & 0.0372 & $(0.0326)$ & 0.0114 & $(0.00959)$ \\
\hline PhD_in_Germany & 0.373 & $(0.248)$ & $0.537^{*}$ & $(0.311)$ & $0.164^{*}$ & $(0.0912)$ \\
\hline Business_Studies & $-0.278^{*}$ & $(0.152)$ & -0.305 & $(0.193)$ & $-0.0931^{*}$ & $(0.0565)$ \\
\hline Sociology_SocialScience & $-0.974^{* * *}$ & $(0.181)$ & $-1.039^{* * *}$ & $(0.226)$ & $-0.317^{* * *}$ & $(0.0621)$ \\
\hline Other30 & $-0.743^{* * *}$ & $(0.169)$ & $-0.775^{* * *}$ & $(0.214)$ & $-0.236^{* * *}$ & $(0.0609)$ \\
\hline Assistant_Professor & -0.130 & $(0.217)$ & 0.0754 & $(0.277)$ & 0.0230 & $(0.0817)$ \\
\hline Research_Assistant & -0.152 & $(0.125)$ & -0.107 & $(0.157)$ & -0.0327 & $(0.0463)$ \\
\hline Status_Habilitation & 0.112 & $(0.119)$ & $0.331^{* *}$ & $(0.148)$ & $0.101^{* *}$ & $(0.0430)$ \\
\hline Lecturer_Admin_Officer & 0.192 & $(0.172)$ & 0.237 & $(0.218)$ & 0.0722 & $(0.0640)$ \\
\hline PhD_program & $0.385^{*}$ & $(0.199)$ & $0.483^{*}$ & $(0.257)$ & $0.147^{* *}$ & $(0.0752)$ \\
\hline PhD_research_institution & -0.0228 & $(0.211)$ & 0.0456 & $(0.268)$ & 0.0139 & $(0.0792)$ \\
\hline ExternalPhd_scholarship & 0.00284 & $(0.191)$ & 0.0437 & $(0.238)$ & 0.0133 & $(0.0702)$ \\
\hline Other27 & -0.0604 & $(0.315)$ & -0.135 & $(0.396)$ & -0.0411 & $(0.117)$ \\
\hline PhD_current_university & $-0.225^{*}$ & $(0.119)$ & $-0.287^{*}$ & $(0.150)$ & $-0.0876^{* *}$ & $(0.0439)$ \\
\hline National_conferences & -0.174 & $(0.151)$ & -0.234 & $(0.190)$ & -0.0713 & $(0.0560)$ \\
\hline International_conferences & 0.00501 & $(0.143)$ & -0.149 & $(0.181)$ & -0.0455 & $(0.0532)$ \\
\hline German_research_institute & -0.211 & $(0.224)$ & -0.143 & $(0.294)$ & -0.0437 & $(0.0867)$ \\
\hline Foreign_research_institute & 0.0581 & $(0.128)$ & 0.266 & $(0.163)$ & $0.0813^{*}$ & $(0.0478)$ \\
\hline Referee_reports & 0.215 & $(0.134)$ & $0.280^{*}$ & $(0.168)$ & $0.0856^{*}$ & $(0.0491)$ \\
\hline Publications & -0.0437 & $(0.122)$ & 0.107 & $(0.156)$ & 0.0326 & $(0.0458)$ \\
\hline Third_party_funded_project & -0.0961 & $(0.116)$ & -0.141 & $(0.148)$ & -0.0431 & $(0.0437)$ \\
\hline Prospects_outside_cat & -0.121 & $(0.0831)$ & -0.104 & $(0.105)$ & -0.0316 & $(0.0310)$ \\
\hline Prospects_outside_5y_cat & 0.0327 & $(0.0798)$ & 0.0415 & $(0.100)$ & 0.0127 & $(0.0296)$ \\
\hline Prospects_academia_cat & $0.244^{* * *}$ & $(0.0803)$ & $0.210^{* *}$ & $(0.101)$ & $0.0641^{* *}$ & $(0.0294)$ \\
\hline Competition_academia_cat & $0.192^{*}$ & $(0.105)$ & $0.240^{*}$ & $(0.131)$ & $0.0731^{*}$ & $(0.0383)$ \\
\hline Networks_n & -0.169 & $(0.103)$ & -0.207 & $(0.129)$ & $-0.0630^{*}$ & $(0.0377)$ \\
\hline Conditions_prospects_cat & $0.188^{* * *}$ & $(0.0693)$ & $0.190^{* *}$ & $(0.0875)$ & $0.0581^{* *}$ & $(0.0255)$ \\
\hline$N$ & 474 & & 474 & & 474 & \\
\hline
\end{tabular}

Marginal effects; Standard errors in parentheses

Values of the dependent variable (categorial): $1=$ decreased

$2=$ slightly decreased, $3=$ not changed, $4=$ slightly improved, $5=$ improved

Values of the dependent variable (binary): $1=$ slightly improved + improved, $0=$ other

(1): Ordered Probit, (2): Probit, (3): Marginal effects of Probit(2)

(d) for discrete change of dummy variable from 0 to 1

${ }^{*} p<0.1,{ }^{* *} p<0.05,{ }^{* * *} p<0.01$ 
Table 16: How do you view your current employment prospects in jobs outside of academic research?

(1)

(2)

(3)

Prospects_outside Prospects_outside_bin Marginal effects

\begin{tabular}{|c|c|c|c|c|c|c|}
\hline \\
\hline \multicolumn{7}{|l|}{$\begin{array}{l}\text { main } \\
\text { Women }\end{array}$} \\
\hline Age & $-0.0461^{* * *}$ & $(0.0152)$ & $-0.0769^{* * *}$ & $(0.0222)$ & $-0.0260^{* * *}$ & $(0.00689)$ \\
\hline Partnership & -0.0313 & $(0.130)$ & -0.00558 & $(0.165)$ & 0.00393 & $(0.0528)$ \\
\hline Single & 0.0829 & $(0.154)$ & 0.0228 & $(0.201)$ & 0.0109 & $(0.0641)$ \\
\hline Other18 & -0.00710 & $(0.310)$ & 0.127 & $(0.413)$ & 0.0419 & $(0.132)$ \\
\hline One_child & $-0.226^{*}$ & $(0.135)$ & -0.256 & $(0.175)$ & -0.0788 & $(0.0557)$ \\
\hline Two_children & -0.165 & $(0.163)$ & -0.205 & $(0.210)$ & -0.0650 & $(0.0669)$ \\
\hline More_children & 0.00737 & $(0.225)$ & 0.123 & $(0.288)$ & 0.0588 & $(0.0922)$ \\
\hline German & 0.221 & $(0.183)$ & $0.410^{*}$ & $(0.236)$ & $0.135 *$ & $(0.0749)$ \\
\hline Years_since_final_degree & -0.00648 & $(0.0197)$ & -0.00906 & $(0.0258)$ & -0.00296 & $(0.00822)$ \\
\hline Master & -0.299 & $(0.228)$ & $-0.507^{*}$ & $(0.292)$ & $-0.171^{*}$ & $(0.0921)$ \\
\hline Magister & $-0.325^{*}$ & $(0.177)$ & -0.293 & $(0.240)$ & -0.102 & $(0.0762)$ \\
\hline Other23 & -0.145 & $(0.188)$ & 0.152 & $(0.243)$ & 0.0356 & $(0.0777)$ \\
\hline Years_since_graduation & 0.0165 & $(0.0207)$ & $0.0434^{*}$ & $(0.0262)$ & $0.0154^{*}$ & $(0.00831)$ \\
\hline PhD_in_Germany & 0.280 & $(0.228)$ & 0.130 & $(0.291)$ & 0.0260 & $(0.0926)$ \\
\hline Business_Studies & $0.293^{* *}$ & $(0.137)$ & 0.259 & $(0.171)$ & $0.0929^{*}$ & $(0.0541)$ \\
\hline Sociology_SocialScience & -0.107 & $(0.157)$ & $-0.440^{* *}$ & $(0.205)$ & $-0.144^{* *}$ & $(0.0646)$ \\
\hline Other30 & 0.253 & $(0.154)$ & 0.0946 & $(0.194)$ & 0.0352 & $(0.0619)$ \\
\hline Assistant_Professor & $-0.450^{* *}$ & $(0.195)$ & $-0.677^{* * *}$ & $(0.249)$ & $-0.215^{* * *}$ & $(0.0782)$ \\
\hline Research_Assistant & $-0.338^{* * *}$ & $(0.113)$ & $-0.304^{* *}$ & $(0.146)$ & $-0.0930^{* *}$ & $(0.0459)$ \\
\hline Status_Habilitation & -0.125 & $(0.108)$ & -0.188 & $(0.138)$ & -0.0680 & $(0.0439)$ \\
\hline Lecturer_Admin_Officer & -0.0311 & $(0.152)$ & -0.0909 & $(0.192)$ & -0.0308 & $(0.0614)$ \\
\hline PhD_program & $0.379^{* *}$ & $(0.176)$ & $0.438^{*}$ & $(0.225)$ & $0.139^{*}$ & $(0.0712)$ \\
\hline PhD_research_institution & 0.00510 & $(0.195)$ & 0.106 & $(0.247)$ & 0.0436 & $(0.0792)$ \\
\hline ExternalPhd_scholarship & -0.246 & $(0.172)$ & -0.137 & $(0.230)$ & -0.0458 & $(0.0735)$ \\
\hline Other27 & -0.0652 & $(0.275)$ & -0.174 & $(0.372)$ & -0.0632 & $(0.119)$ \\
\hline PhD_current_university & 0.0751 & $(0.105)$ & 0.0366 & $(0.134)$ & 0.0179 & $(0.0429)$ \\
\hline National_conferences & -0.187 & $(0.134)$ & -0.193 & $(0.172)$ & -0.0650 & $(0.0548)$ \\
\hline International_conferences & 0.203 & $(0.127)$ & $0.319^{*}$ & $(0.166)$ & $0.102^{*}$ & $(0.0524)$ \\
\hline German_research_institute & $-0.339^{*}$ & $(0.206)$ & $-0.895^{* * *}$ & $(0.282)$ & $-0.284^{* * *}$ & $(0.0867)$ \\
\hline Foreign_research_institute & -0.0488 & $(0.116)$ & -0.104 & $(0.150)$ & -0.0317 & $(0.0478)$ \\
\hline Referee_reports & -0.0135 & $(0.120)$ & -0.0752 & $(0.154)$ & -0.0267 & $(0.0490)$ \\
\hline Publications & 0.0976 & $(0.110)$ & 0.153 & $(0.141)$ & 0.0470 & $(0.0448)$ \\
\hline Third_party_funded_project & $0.187^{*}$ & $(0.103)$ & $0.215^{*}$ & $(0.131)$ & $0.0736^{*}$ & $(0.0415)$ \\
\hline Prospects_academia_cat & 0.0725 & $(0.0728)$ & 0.00877 & $(0.0937)$ & 0.0135 & $(0.0296)$ \\
\hline Competition_academia_cat & -0.0822 & $(0.0969)$ & -0.126 & $(0.124)$ & -0.0378 & $(0.0393)$ \\
\hline Networks_n & 0.0227 & $(0.0925)$ & 0.0979 & $(0.118)$ & 0.0281 & $(0.0375)$ \\
\hline Conditions_prospects_cat & -0.0298 & $(0.0718)$ & 0.00178 & $(0.0903)$ & 0.0335 & $(0.0251)$ \\
\hline Conditions_prospects_catI & $0.285^{* *}$ & $(0.119)$ & $0.348^{* *}$ & $(0.154)$ & & \\
\hline$N$ & 528 & & 528 & & 020 & \\
\hline
\end{tabular}

Marginal effects; Standard errors in parentheses

Values of the dependent variable (categorial): $1=$ very bad, $2=$ rather bad

$3=$ average, $4=$ rather good, $5=$ very good

Values of the dependent variable (binary): $1=$ rather good + very good

(1): Ordered Probit, (2): Probit, (3): Marginal effects of Probit(2)

(d) for discrete change of dummy variable from 0 to 1

${ }^{*} p<0.1,{ }^{* *} p<0.05,{ }^{* * *} p<0.01$ 
Table 17: How do you view your employment prospects in jobs outside of academic research five years from now, assuming that you continue working in an academic job?

\begin{tabular}{|c|c|c|c|c|c|c|}
\hline \multirow{2}{*}{ main } & \multicolumn{2}{|c|}{$\begin{array}{c}\text { (1) } \\
\text { Prospects_outside_5y }\end{array}$} & \multicolumn{2}{|c|}{$\begin{array}{c}(2) \\
\text { Prospects_outside_bin }\end{array}$} & \multicolumn{2}{|c|}{ Marginal effects } \\
\hline & & & & & & \\
\hline Women & $-0.213^{* *}$ & $(0.106)$ & -0.112 & $(0.137)$ & -0.0237 & $(0.0361)$ \\
\hline Age & $-0.0353^{* *}$ & $(0.0159)$ & $-0.0769^{* * *}$ & $(0.0222)$ & -0.00181 & $(0.00569)$ \\
\hline Partnership & -0.0275 & $(0.129)$ & -0.00558 & $(0.165)$ & -0.0607 & $(0.0462)$ \\
\hline Single & 0.181 & $(0.153)$ & 0.0228 & $(0.201)$ & 0.00971 & $(0.0534)$ \\
\hline Other18 & 0.214 & $(0.307)$ & 0.127 & $(0.413)$ & 0.0713 & $(0.105)$ \\
\hline One_child & -0.0746 & $(0.135)$ & -0.256 & $(0.175)$ & -0.0395 & $(0.0491)$ \\
\hline Two_children & -0.0886 & $(0.163)$ & -0.205 & $(0.210)$ & -0.0129 & $(0.0567)$ \\
\hline More_children & 0.177 & $(0.221)$ & 0.123 & $(0.288)$ & 0.0225 & $(0.0779)$ \\
\hline German & 0.193 & $(0.184)$ & $0.410^{*}$ & $(0.236)$ & 0.0459 & $(0.0647)$ \\
\hline Years_since_final_degree & -0.00265 & $(0.0199)$ & -0.00906 & $(0.0258)$ & -0.000183 & $(0.00703)$ \\
\hline Master & $0.504^{* *}$ & $(0.227)$ & $-0.507^{*}$ & $(0.292)$ & $0.154^{* *}$ & $(0.0762)$ \\
\hline Magister & -0.133 & $(0.1$ & -0.293 & $(0.2)$ & -0.00272 & $(0.0693)$ \\
\hline Other23 & -0.0349 & $(0.1$ & 0.152 & $(0.243)$ & 0.0880 & $(0.0648)$ \\
\hline Years_since_gradua & $0.0420^{* *}$ & $(0.02-5)$ & $0.0434^{*}$ & $(0.0262)$ & 0.00156 & $(0.00718)$ \\
\hline PhD_in_Germany & 0.239 & $(0.227)$ & 0.130 & $(0.291)$ & 0.0984 & $(0.0843)$ \\
\hline Business_Studies & 0.00912 & $(0.135)$ & 0.259 & $(0.171)$ & 0.0184 & $(0.0466)$ \\
\hline Sociology_SocialScience & -0.0365 & $(0.157)$ & $-0.440^{* *}$ & $(0.205)$ & -0.0458 & $(0.0591)$ \\
\hline Other30 & -0.0225 & $(0.1$ & 0.0946 & $(0.194)$ & -0.000133 & $(0.0541)$ \\
\hline Assistant_Professor & -0.176 & $(0.1$ & $-0.677^{* * *}$ & $(0.249)$ & -0.0113 & $(0.0643)$ \\
\hline Research_Ass & $-0.252^{* *}$ & $(0.112)$ & $-0.304^{* *}$ & $(0.146)$ & $-0.0984^{* *}$ & $(0.0387)$ \\
\hline Status_Habilitation & 0.00496 & $(0.107)$ & -0.188 & $(0.138)$ & -0.00434 & $(0.0379)$ \\
\hline Lecturer_Admin_Officer & -0.164 & $(0.151)$ & -0.0909 & $(0.192)$ & $-0.0949^{*}$ & $(0.0519)$ \\
\hline PhD_program & $0.332^{*}$ & $(0.174)$ & $0.438^{*}$ & $(0.225)$ & 0.00337 & $(0.0622)$ \\
\hline PhD_research_il & -0.141 & $(0.1$ & 0.106 & $(0.2$ & -0.118 & $(0.0734)$ \\
\hline ExternalPhd_scholarship & 0.0173 & $(0.1$ & -0.137 & $(0.230)$ & -0.0620 & $(0.0667)$ \\
\hline Other27 & -0.0108 & $(0.2$ & -0.174 & $(0.372)$ & 0.0154 & $(0.0945)$ \\
\hline PhD_current_univ & 0.125 & $(0.104)$ & 0.0366 & $(0.134)$ & 0.0220 & $(0.0369)$ \\
\hline National_conferences & -0.0371 & $(0.134)$ & -0.193 & $(0.172)$ & -0.0466 & $(0.0472)$ \\
\hline International_conferences & -0.0938 & $(0.127)$ & $0.319^{*}$ & $(0.166)$ & -0.00851 & $(0.0455)$ \\
\hline German_research_institute & -0.0678 & $(0.204)$ & $-0.895^{* * *}$ & $(0.282)$ & -0.135 & $(0.0855)$ \\
\hline Foreign_research_institute & -0.148 & $(0.117)$ & -0.104 & $(0.150)$ & -0.0413 & $(0.0415)$ \\
\hline Referee_reports & -0.142 & $(0.119)$ & -0.0752 & $(0.154)$ & 0.0362 & $(0.0418)$ \\
\hline Publications & $0.220^{* *}$ & $(0.110)$ & 0.153 & $(0.141)$ & 0.0413 & $(0.0395)$ \\
\hline Third_party_funded_project & 0.134 & $(0.102)$ & $0.215^{*}$ & $(0.131)$ & 0.00598 & $(0.0358)$ \\
\hline Prospects_academia_cat & 0.0615 & $(0.0724)$ & 0.00877 & $(0.0937)$ & 0.0147 & $(0.0256)$ \\
\hline Competition_academia_cat & $-0.240^{* *}$ & $(0.0959)$ & -0.126 & $(0.124)$ & $-0.0632^{* *}$ & $(0.0317)$ \\
\hline Networks_n & -0.0694 & $(0.0920)$ & 0.0979 & $(0.118)$ & -0.0376 & $(0.0326)$ \\
\hline Conditions_prospects_cat & $0.200^{* * *}$ & $(0.0623)$ & 0.00178 & $(0.0903)$ & $0.0747^{* * *}$ & $(0.0220)$ \\
\hline Conditions_prospects_catI & & & $0.348^{* *}$ & $(0.154)$ & & \\
\hline$N$ & 528 & & 528 & & 528 & \\
\hline
\end{tabular}

Marginal effects; Standard errors in parentheses

Values of the dependent variable (categorial): $1=$ very bad

$2=$ rather bad, $3=$ average, $4=$ rather good, $5=$ very good

Values of the dependent variable (binary): $1=$ rather good + very good, $0=$ other

(1): Ordered Probit, (2): Probit, (3): Marginal effects of Probit(2)

(d) for discrete change of dummy variable from 0 to 1

${ }^{*} p<0.1,{ }^{* *} p<0.05,{ }^{* * *} p<0.01$ 
Table 18: How do you assess your own prospects to successfully pursue an academic career?

(1)

(2)

(3)

Prospects

Prospects_bin

Marginal effects

\begin{tabular}{|c|c|c|c|c|c|c|}
\hline \multicolumn{7}{|l|}{ main } \\
\hline Women & 0.0760 & $(0.109)$ & 0.166 & $(0.149)$ & 0.0476 & $(0.0388)$ \\
\hline Age & -0.0135 & $(0.0158)$ & -0.0124 & $(0.0237)$ & -0.00704 & $(0.00639)$ \\
\hline Partnership & $-0.319^{* *}$ & $(0.134)$ & $-0.414^{* *}$ & $(0.184)$ & $-0.105^{* *}$ & $(0.0486)$ \\
\hline Single & $-0.271^{*}$ & $(0.160)$ & -0.217 & $(0.222)$ & -0.0712 & $(0.0586)$ \\
\hline Other18 & 0.0501 & $(0.320)$ & -0.122 & $(0.413)$ & -0.0619 & $(0.111)$ \\
\hline One_child & $-0.347^{* *}$ & $(0.140)$ & $-0.454^{* *}$ & $(0.191)$ & $-0.123^{* *}$ & $(0.0503)$ \\
\hline Two_children & $-0.490^{* * *}$ & $(0.167)$ & $-0.683^{* * *}$ & $(0.227)$ & $-0.181^{* * *}$ & $(0.0596)$ \\
\hline More_children & $-0.651^{* * *}$ & $(0.227)$ & $-0.982^{* * *}$ & $(0.333)$ & $-0.250^{* * *}$ & $(0.0865)$ \\
\hline German & -0.128 & $(0.190)$ & -0.104 & $(0.257)$ & -0.0141 & $(0.0677)$ \\
\hline Years_since_final_degree & -0.00904 & $(0.0202)$ & -0.0104 & $(0.0291)$ & -0.000406 & $(0.00759)$ \\
\hline Master & -0.0705 & $(0.239)$ & 0.191 & $(0.325)$ & 0.0376 & $(0.0851)$ \\
\hline Magister & $0.301^{*}$ & $(0.183)$ & 0.363 & $(0.249)$ & 0.0866 & $(0.0654)$ \\
\hline Other23 & 0.148 & $(0.195)$ & 0.261 & $(0.260)$ & 0.0935 & $(0.0688)$ \\
\hline Years_since_graduation & -0.00634 & $(0.0221)$ & -0.0153 & $(0.0320)$ & 0.00258 & $(0.00779)$ \\
\hline PhD_in_Germany & -0.198 & $(0.237)$ & -0.380 & $(0$. & -0.128 & $(0.0846)$ \\
\hline Business_Studies & $0.332^{* *}$ & $(0.141)$ & 0.224 & $(0$. & 0.0613 & $(0.0510)$ \\
\hline Sociology_SocialScience & 0.169 & $(0.163)$ & 0.0160 & $(0.222)$ & 0.00942 & $(0.0591)$ \\
\hline Other30 & 0.0422 & $(0.158)$ & -0.128 & $(0.216)$ & -0.0360 & $(0.0572)$ \\
\hline Assistant_Pro & $0.436^{* *}$ & $(0.203)$ & $0.988^{* * *}$ & $(0.2$ & $0.271^{* * *}$ & $(0.0752)$ \\
\hline Resear & -0.134 & $(0.117)$ & -0.157 & $(0.1$ & -0.0402 & $(0.0412)$ \\
\hline Status_Habilitat & 0.44 & $(0.1$ & $0.581^{* * *}$ & $(0.145)$ & $0.160^{* * *}$ & $(0.0367)$ \\
\hline Lecturer_Admin_Officer & -0.0518 & $(0.156)$ & -0.256 & $(0.213)$ & -0.0707 & $(0.0558)$ \\
\hline PhD_program & 0.0359 & $(0.182)$ & -0.00946 & $(0.245)$ & -0.0189 & $(0.0645)$ \\
\hline PhD_research_institution & 0.224 & $(0.202)$ & 0.122 & $(0.274)$ & 0.0343 & $(0.0726)$ \\
\hline ExternalPhd_scholarship & 0.0772 & $(0.1$ & 0.0887 & $(0.2$ & 0.0218 & $(0.0644)$ \\
\hline Other27 & 0.378 & $(0.289)$ & 0.481 & $(0.405)$ & 0.128 & $(0.107)$ \\
\hline PhD_curren & $-0.285^{* * *}$ & $(0.108)$ & -0.138 & $(0.146)$ & -0.0300 & $(0.0388)$ \\
\hline National_conferences & $0.398^{* * *}$ & $(0.137)$ & $0.515^{* * *}$ & $(0.187)$ & $0.152^{* * *}$ & $(0.0486)$ \\
\hline International_conferences & -0.0567 & $(0.151)$ & 0.129 & $(0.204)$ & -0.0291 & $(0.0470)$ \\
\hline German_research_institute & -0.161 & $(0.212)$ & $-0.637^{* *}$ & $(0.286)$ & $-0.158^{* *}$ & $(0.0752)$ \\
\hline Foreign_research_institute & $0.339^{* * *}$ & $(0.121)$ & 0.206 & $(0.163)$ & 0.0596 & $(0.0429)$ \\
\hline Referee & $0.331^{* * *}$ & $(0.123)$ & $0.376^{* *}$ & $(0.163)$ & $0.102^{* *}$ & $(0.0429)$ \\
\hline Publications & 0.140 & $(0.113)$ & $0.396^{* * *}$ & $(0.151)$ & $0.101^{* * *}$ & $(0.0392)$ \\
\hline Third_party_funded_project & -0.141 & $(0.106)$ & -0.126 & $(0.144)$ & -0.0399 & $(0.0381)$ \\
\hline Prospects_outside_cat & 0.0108 & $(0.0765)$ & 0.0953 & $(0.104)$ & 0.0318 & $(0.0274)$ \\
\hline Prospects_outside_5y_cat & $0.141^{*}$ & $(0.0743)$ & -0.0441 & $(0.0988)$ & -0.00799 & $(0.0262)$ \\
\hline Competition_academia_cat & -0.0655 & $(0.101)$ & $-0.226^{*}$ & $(0.137)$ & $-0.0638^{*}$ & $(0.0361)$ \\
\hline Networks_n & $-0.444^{* * *}$ & $(0.115)$ & $-0.603^{* * *}$ & $(0.163)$ & $-0.124^{* * *}$ & $(0.0333)$ \\
\hline Conditions_prospects_cat & $0.393^{* * *}$ & $(0.0729)$ & $0.371^{* * *}$ & $(0.0967)$ & $0.145^{* * *}$ & $(0.0192)$ \\
\hline Years_since_graduationI & $0.0434^{* *}$ & $(0.0208)$ & 0.0419 & $(0.0302)$ & & \\
\hline International_conferencesI & -0.00995 & $(0.226)$ & $-0.667^{* *}$ & $(0.311)$ & & \\
\hline Networks_nI & 0.166 & $(0.199)$ & $0.545^{* *}$ & $(0.276)$ & & \\
\hline Conditions_prospects_catI & $0.356^{* * *}$ & $(0.127)$ & $0.543^{* * *}$ & $(0.180)$ & & \\
\hline$N$ & 528 & & 528 & & 528 & \\
\hline
\end{tabular}

Marginal effects; Standard errors in parentheses

Values of the dependent variable (categorial): $1=$ very bad

$2=$ rather bad, $3=$ neutral, $4=$ rather good, $5=$ very good

Values of the dependent variable (binary): $1=$ rather good + very good, $0=$ other

(1): Ordered Probit, (2): Probit, (3): Marginal effects of Probit(2)

(d) for discrete change of dummy variable from 0 to 1

${ }^{*} p<0.1,{ }^{* *} p<0.05,{ }^{* * *} p<0.01$ 
Table 19: How do the conditions in your current job and your future employment prospects affect your motivation/incentives to engage in an acedemic career?

\begin{tabular}{|c|c|c|c|c|c|c|}
\hline \multirow[b]{2}{*}{ main } & \multicolumn{2}{|c|}{$\begin{array}{c}(1) \\
\text { Conditions }\end{array}$} & \multicolumn{2}{|c|}{$\begin{array}{c}(2) \\
\text { Conditions_bin }\end{array}$} & \multicolumn{2}{|c|}{$\begin{array}{c}(3) \\
\text { Marginal effects }\end{array}$} \\
\hline & & & & & & \\
\hline Women & 0.0605 & $(0.108)$ & 0.0173 & $(0.140)$ & 0.0161 & $(0.0441)$ \\
\hline Age & $-0.0317^{*}$ & $(0.0165)$ & -0.0259 & $(0.0221)$ & -0.00902 & $(0.00703)$ \\
\hline Partnership & -0.0560 & $(0.132)$ & 0.0140 & $(0.167)$ & 0.00378 & $(0.0533)$ \\
\hline Single & -0.0781 & $(0.157)$ & -0.0578 & $(0.201)$ & -0.0255 & $(0.0638)$ \\
\hline Other18 & -0.359 & $(0.306)$ & -0.157 & $(0.381)$ & -0.0730 & $(0.123)$ \\
\hline One_child & 0.00348 & $(0.138)$ & 0.0563 & $(0.175)$ & 0.0152 & $(0.0558)$ \\
\hline Two_children & 0.268 & $(0.167)$ & 0.334 & $(0.211)$ & 0.108 & $(0.0669)$ \\
\hline More_children & $0.427^{*}$ & $(0.228)$ & 0.400 & $(0.282)$ & 0.127 & $(0.0908)$ \\
\hline German & -0.0826 & $(0.186)$ & -0.107 & $(0.233)$ & -0.0344 & $(0.0745)$ \\
\hline Years_since_final_degree & 0.0136 & $(0.0202)$ & 0.0277 & $(0.0274)$ & 0.00717 & $(0.00860)$ \\
\hline Master & -0.362 & $(0.233)$ & -0.0806 & $(0.294)$ & -0.0300 & $(0.0945)$ \\
\hline Magister & 0.123 & $(0.180)$ & 0.166 & $(0.227)$ & 0.0562 & $(0.0728)$ \\
\hline Other23 & 0.237 & $(0.193)$ & -0.0321 & $(0.248)$ & -0.0222 & $(0.0788)$ \\
\hline Years_since_graduation & 0.00109 & $(0.0210)$ & -0.0233 & $(0.0277)$ & -0.00415 & $(0.00872)$ \\
\hline PhD_in_Germany & 0.0449 & $(0.227)$ & 0.317 & $(0.287)$ & 0.114 & $(0.0926)$ \\
\hline Business_Studies & -0.0933 & $(0.138)$ & -0.0654 & $(0.175)$ & -0.0235 & $(0.0561)$ \\
\hline Sociology_SocialScience & 0.0746 & $(0.160)$ & 0.0417 & $(0.205)$ & 0.0118 & $(0.0658)$ \\
\hline Other30 & -0.0730 & $(0.156)$ & -0.0643 & $(0.197)$ & -0.0235 & $(0.0629)$ \\
\hline Assistant_Professor & 0.0367 & $(0.200)$ & 0.321 & $(0.251)$ & 0.114 & $(0.0802)$ \\
\hline Research_Assistant & -0.0237 & $(0.114)$ & 0.103 & $(0.145)$ & 0.0422 & $(0.0465)$ \\
\hline Status_Habilitation & 0.0599 & $(0.109)$ & 0.109 & $(0.138)$ & 0.0240 & $(0.0440)$ \\
\hline Lecturer_Admin_Officer & 0.0192 & $(0.153)$ & 0.113 & $(0.191)$ & 0.0422 & $(0.0616)$ \\
\hline PhD_program & $-0.321^{*}$ & $(0.177)$ & -0.234 & $(0.222)$ & -0.0787 & $(0.0708)$ \\
\hline PhD_research_institution & $0.341^{*}$ & $(0.203)$ & 0.412 & $(0.265)$ & 0.134 & $(0.0844)$ \\
\hline ExternalPhd_scholarship & -0.176 & $(0.174)$ & -0.0432 & $(0.225)$ & -0.00909 & $(0.0719)$ \\
\hline Other27 & 0.0606 & $(0.280)$ & -0.0339 & $(0.368)$ & -0.00598 & $(0.117)$ \\
\hline PhD_current_university & -0.157 & $(0.126)$ & -0.170 & $(0.156)$ & -0.00458 & $(0.0429)$ \\
\hline National_conferences & 0.165 & $(0.136)$ & 0.108 & $(0.174)$ & 0.0387 & $(0.0559)$ \\
\hline International_conferences & 0.191 & $(0.127)$ & 0.255 & $(0.162)$ & $0.0880^{*}$ & $(0.0518)$ \\
\hline German_research_institute & 0.0708 & $(0.209)$ & 0.0626 & $(0.259)$ & 0.0376 & $(0.0834)$ \\
\hline Foreign_research_institute & -0.101 & $(0.118)$ & -0.0687 & $(0.148)$ & -0.0268 & $(0.0476)$ \\
\hline Referee_reports & $-0.203^{*}$ & $(0.121)$ & -0.238 & $(0.152)$ & -0.0790 & $(0.0487)$ \\
\hline Publications & -0.175 & $(0.111)$ & 0.0156 & $(0.140)$ & 0.00175 & $(0.0449)$ \\
\hline Third_party_funded_project & 0.157 & $(0.104)$ & 0.0329 & $(0.131)$ & 0.00706 & $(0.0422)$ \\
\hline Prospects_outside_cat & -0.0373 & $(0.0754)$ & -0.0108 & $(0.0966)$ & -0.00210 & $(0.0309)$ \\
\hline Prospects_outside_5y_cat & $0.245^{* * *}$ & $(0.0729)$ & $0.157^{*}$ & $(0.0914)$ & $0.0518^{*}$ & $(0.0289)$ \\
\hline Prospects_academia_cat & $0.517^{* * *}$ & $(0.0822)$ & $0.420^{* * *}$ & $(0.102)$ & $0.185^{* * *}$ & $(0.0248)$ \\
\hline Competition_academia_cat & 0.143 & $(0.0996)$ & 0.105 & $(0.126)$ & 0.0391 & $(0.0397)$ \\
\hline Networks_n & $-0.255^{* * *}$ & $(0.0925)$ & $-0.270^{* *}$ & $(0.117)$ & $-0.0854^{* *}$ & $(0.0372)$ \\
\hline PhD_current_univ & $0.475^{* *}$ & $(0.208)$ & $0.515^{*}$ & $(0.269)$ & & \\
\hline Prospects_academia_catI & $0.300^{* *}$ & $(0.126)$ & $0.420^{* *}$ & $(0.171)$ & & \\
\hline$N$ & 528 & & 528 & & J20 & \\
\hline
\end{tabular}

Marginal effects; Standard errors in parentheses

Values of the dependent variable (categorial):

$1=$ strongly negative, $2=$ weakly negative, $3=$ average, $4=$ weakly positive, $5=$ strongly positive

Values of the dependent variable (binary): $1=$ weakly positive + strongly positive , $0=$ other

(1): Ordered Probit, (2): Probit, (3): Marginal Effects of Probit(2)

(d) for discrete change of dummy variable from 0 to 1

${ }^{*} p<0.1,{ }^{* *} p<0.05,{ }^{* * *} p<0.01$ 
Table 20: In comparison to a job outside of academic research, an academic research job is more risky.

$$
\text { (1) }
$$

Academic job risk, probit Academic job risk, AME

\begin{tabular}{|c|c|c|c|c|}
\hline Female & -0.101 & $(0.134)$ & -0.0346 & $(0.0460)$ \\
\hline Age & 0.0303 & $(0.0215)$ & 0.0103 & $(0.00728)$ \\
\hline Partnership & 0.279 & $(0.163)$ & 0.0947 & $(0.0548)$ \\
\hline Single & -0.0255 & $(0.192)$ & -0.00867 & $(0.0652)$ \\
\hline Other family status & 0.255 & $(0.402)$ & 0.0867 & $(0.137)$ \\
\hline One child & -0.0717 & $(0.170)$ & -0.0244 & $(0.0579)$ \\
\hline Two children & 0.265 & $(0.207)$ & 0.0900 & $(0.0700)$ \\
\hline More children & -0.0848 & $(0.277)$ & -0.0288 & $(0.0942)$ \\
\hline German & 0.253 & $(0.231)$ & 0.0860 & $(0.0783)$ \\
\hline Years since final degree & $-0.0627^{*}$ & $(0.0269)$ & $-0.0213^{*}$ & $(0.00899)$ \\
\hline Master & $-0.594^{*}$ & $(0.296)$ & $-0.202^{*}$ & $(0.0994)$ \\
\hline Magister & 0.0491 & $(0.226)$ & 0.0167 & $(0.0767)$ \\
\hline Other academic degree & 0.174 & $(0.241)$ & 0.0593 & $(0.0820)$ \\
\hline Years since graduation & 0.0187 & $(0.0269)$ & 0.00636 & $(0.00914)$ \\
\hline PhD in Germany & -0.193 & $(0.301)$ & -0.0656 & $(0.102)$ \\
\hline Business Studies & 0.0502 & $(0.171)$ & 0.0171 & $(0.0581)$ \\
\hline Sociology, Social Sciences & -0.153 & $(0.199)$ & -0.0519 & $(0.0674)$ \\
\hline Other subject & -0.0558 & $(0.196)$ & -0.0190 & $(0.0668)$ \\
\hline Assistant Professor & -0.100 & $(0.248)$ & -0.0340 & $(0.0843)$ \\
\hline Research Assistant & -0.00860 & $(0.142)$ & -0.00292 & $(0.0482)$ \\
\hline Status Habilitation & 0.179 & $(0.135)$ & 0.0608 & $(0.0459)$ \\
\hline Lecturer, Admin, Officer & 0.0948 & $(0.192)$ & 0.0322 & $(0.0652)$ \\
\hline $\mathrm{PhD}$ program & 0.327 & $(0.234)$ & 0.111 & $(0.0792)$ \\
\hline $\mathrm{PhD}$ research institution & -0.0811 & $(0.240)$ & -0.0276 & $(0.0815)$ \\
\hline External PhD scholarship & -0.0467 & $(0.216)$ & -0.0159 & $(0.0733)$ \\
\hline Other PhD & $-0.799^{*}$ & $(0.352)$ & $-0.272^{*}$ & $(0.118)$ \\
\hline PhD current university & -0.179 & $(0.131)$ & -0.0608 & $(0.0444)$ \\
\hline National conferences & -0.109 & $(0.168)$ & -0.0371 & $(0.0571)$ \\
\hline International conferences & $0.467^{* *}$ & $(0.159)$ & $0.159^{* *}$ & $(0.0529)$ \\
\hline German research institute & -0.177 & $(0.259)$ & -0.0603 & $(0.0881)$ \\
\hline Foreign research institute & -0.136 & $(0.150)$ & -0.0462 & $(0.0508)$ \\
\hline Referee reports & -0.135 & $(0.152)$ & -0.0458 & $(0.0516)$ \\
\hline Publications & 0.0553 & $(0.139)$ & 0.0188 & $(0.0472)$ \\
\hline Third-party project & -0.0552 & $(0.130)$ & -0.0188 & $(0.0442)$ \\
\hline Prospects outside & -0.106 & $(0.0951)$ & -0.0360 & $(0.0322)$ \\
\hline Prospects outside $5 \mathrm{y}$ & $-0.277^{* *}$ & $(0.0895)$ & $-0.0940^{* *}$ & $(0.0296)$ \\
\hline Prospects academia & 0.0198 & $(0.0917)$ & 0.00674 & $(0.0312)$ \\
\hline Competition academia & $0.339^{* *}$ & $(0.121)$ & $0.115^{* *}$ & $(0.0401)$ \\
\hline Networks & 0.0519 & $(0.116)$ & 0.0176 & $(0.0394)$ \\
\hline Conditions prospects & -0.0299 & $(0.0794)$ & -0.0102 & $(0.0270)$ \\
\hline$N$ & 528 & & 528 & \\
\hline
\end{tabular}

Marginal effects; Standard errors in parentheses

Values of the dependent variable (binary): $1=$ Yes $0=$ No

(d) for discrete change of dummy variable from 0 to 1

${ }^{*} p<0.05,{ }^{* *} p<0.01,{ }^{* * *} p<0.001$ 
Table 21: What kind of job will you probably have in five years?

\begin{tabular}{|c|c|c|c|c|c|c|}
\hline \multirow[b]{2}{*}{ main } & \multicolumn{2}{|c|}{$\begin{array}{c}(1) \\
\text { Job_in5y }\end{array}$} & \multicolumn{2}{|c|}{$\stackrel{(2)}{\text { Job_in5y_bin }}$} & \multicolumn{2}{|c|}{ Marginal effects } \\
\hline & & & & & & \\
\hline Women & -0.101 & $(0.118)$ & -0.00751 & $(0.174)$ & -0.00163 & $(0.0365)$ \\
\hline Age & 0.00424 & $(0.0171)$ & 0.0165 & $(0.0243)$ & 0.00358 & $(0.00509)$ \\
\hline Partnership & -0.178 & $(0.141)$ & -0.150 & $(0.203)$ & -0.0325 & $(0.0425)$ \\
\hline Single & -0.0229 & $(0.171)$ & 0.173 & $(0.251)$ & 0.0377 & $(0.0527)$ \\
\hline Other18 & 0.100 & $(0.349)$ & 0.0920 & $(0.479)$ & 0.0200 & $(0.101)$ \\
\hline One_child & 0.0708 & $(0.150)$ & 0.183 & $(0.218)$ & 0.0397 & $(0.0457)$ \\
\hline Two_children & -0.158 & $(0.181)$ & 0.0231 & $(0.265)$ & 0.00503 & $(0.0558)$ \\
\hline More_children & -0.0000140 & $(0.251)$ & 0.579 & $(0.369)$ & 0.126 & $(0.0770)$ \\
\hline German & -0.0729 & $(0.213)$ & 0.180 & $(0.322)$ & 0.0390 & $(0.0677)$ \\
\hline Years_since_final_degree & 0.0146 & $(0.0257)$ & -0.0356 & $(0.0364)$ & -0.00772 & $(0.00764)$ \\
\hline Master & 0.212 & $(0.259)$ & 0.344 & $(0.394)$ & 0.0748 & $(0.0827)$ \\
\hline Magister & 0.203 & $(0.197)$ & $0.544^{*}$ & $(0.292)$ & $0.118^{*}$ & $(0.0607)$ \\
\hline Other23 & 0.0391 & $(0.216)$ & 0.128 & $(0.308)$ & 0.0278 & $(0.0647)$ \\
\hline Years_since_graduation & 0.0204 & $(0.0259)$ & 0.0398 & $(0.0358)$ & 0.00865 & $(0.00751)$ \\
\hline PhD_in_Germany & $-0.437^{*}$ & $(0.257)$ & $-1.092^{* * *}$ & $(0.422)$ & $-0.237^{* * *}$ & $(0.0868)$ \\
\hline Business_Studies & $0.418^{* * *}$ & $(0.151)$ & $0.391^{*}$ & $(0.223)$ & $0.0849^{*}$ & $(0.0464)$ \\
\hline Sociology_SocialScience & $0.300^{*}$ & $(0.174)$ & 0.373 & $(0.251)$ & 0.0811 & $(0.0525)$ \\
\hline Other30 & $0.331^{*}$ & $(0.170)$ & $0.414^{*}$ & $(0.250)$ & $0.0899^{*}$ & $(0.0521)$ \\
\hline Assistant_Prof & 0.206 & $(0.222)$ & $0.697^{*}$ & $(0.367)$ & $0.151^{* *}$ & $(0.0765)$ \\
\hline Research_Assistant & -0.170 & $(0.123)$ & $-0.344^{* *}$ & $(0.174)$ & $-0.0748^{* *}$ & $(0.0361)$ \\
\hline Status_Habilitation & $0.313^{* * *}$ & $(0.117)$ & $0.322^{*}$ & $(0.165)$ & $0.0700^{* *}$ & $(0.0344)$ \\
\hline Lecturer_Admin_Officer & $0.456^{* * *}$ & $(0.172)$ & $0.489^{*}$ & $(0.252)$ & $0.106^{* *}$ & $(0.0524)$ \\
\hline PhD_program & -0.281 & $(0.193)$ & -0.340 & $(0.273)$ & -0.0738 & $(0.0572)$ \\
\hline PhD_research_institution & -0.161 & $(0.221)$ & -0.295 & $(0.328)$ & -0.0640 & $(0.0687)$ \\
\hline ExternalPhd_scholarship & 0.142 & $(0.187)$ & 0.231 & $(0.263)$ & 0.0503 & $(0.0553)$ \\
\hline Other27 & -0.221 & $(0.340)$ & -0.485 & $(0.503)$ & -0.105 & $(0.106)$ \\
\hline PhD_current_university & -0.154 & $(0.115)$ & 0.151 & $(0.168)$ & 0.0327 & $(0.0351)$ \\
\hline National_conferences & -0.149 & $(0.149)$ & -0.123 & $(0.218)$ & -0.0266 & $(0.0457)$ \\
\hline International_conferences & 0.195 & $(0.140)$ & 0.325 & $(0.198)$ & $0.0705^{*}$ & $(0.0414)$ \\
\hline German_research_institute & -0.358 & $(0.227)$ & -0.138 & $(0.320)$ & -0.0300 & $(0.0672)$ \\
\hline Foreign_research_institute & -0.0361 & $(0.127)$ & -0.144 & $(0.186)$ & -0.0312 & $(0.0391)$ \\
\hline Referee_reports & 0.167 & $(0.133)$ & 0.158 & $(0.189)$ & 0.0343 & $(0.0395)$ \\
\hline Publications & -0.0644 & $(0.120)$ & -0.141 & $(0.174)$ & -0.0307 & $(0.0366)$ \\
\hline Third_party_funded_project & 0.158 & $(0.113)$ & 0.189 & $(0.166)$ & 0.0411 & $(0.0347)$ \\
\hline Prospects_outside_cat & $-0.277^{* * *}$ & $(0.0826)$ & $-0.411^{* * *}$ & $(0.122)$ & $-0.0893^{* * *}$ & $(0.0249)$ \\
\hline Prospects_outside_5y_cat & 0.0517 & $(0.0789)$ & -0.0298 & $(0.112)$ & -0.00647 & $(0.0236)$ \\
\hline Prospects_academia_cat & $0.770^{* * *}$ & $(0.0809)$ & $0.865^{* * *}$ & $(0.111)$ & $0.188^{* * *}$ & $(0.0192)$ \\
\hline Competition_academia_cat & 0.148 & $(0.106)$ & -0.0424 & $(0.151)$ & -0.00920 & $(0.0317)$ \\
\hline Networks_n & $-0.367^{* * *}$ & $(0.102)$ & $-0.241^{*}$ & $(0.145)$ & $-0.0524^{*}$ & $(0.0303)$ \\
\hline Conditions_prospects_cat & $0.285^{* * *}$ & $(0.0676)$ & $0.431^{* * *}$ & $(0.0928)$ & $0.0936^{* * *}$ & $(0.0182)$ \\
\hline$N$ & 498 & & 498 & & 498 & \\
\hline
\end{tabular}

Marginal effects; Standard errors in parentheses

Values of the dependent variable (categorial): $1=a$ job outside of academic research

$2=$ rather a job outside of academic research

$3=$ no preference, $4=$ rather an academic research job, $5=$ an academic research job

Values of the dependent variable (binary):

$1=$ rather an academic research job + an academic research job, $0=$ other

(1): Ordered Probit, (2): Probit, (3): Marginal effects of Probit(2)

(d) for discrete change of dummy variable from 0 to 1

${ }^{*} p<0.1,{ }^{* *} p<0.05,{ }^{* * *} p<0.01$ 
Table 22: If you could choose, what kind of job would you select at present?

\begin{tabular}{|c|c|c|c|c|c|c|}
\hline main & \multicolumn{2}{|c|}{$\begin{array}{c}(1) \\
\text { Choice }\end{array}$} & \multicolumn{2}{|c|}{$\begin{array}{c}(2) \\
\text { Choice_bin }\end{array}$} & \multicolumn{2}{|c|}{$\begin{array}{c}(3) \\
\text { Marginal effects }\end{array}$} \\
\hline & & & & & & \\
\hline Women & -0.000778 & $(0.119)$ & 0.0899 & $(0.165)$ & 0.0212 & $(0.0350)$ \\
\hline Age & 0.0124 & $(0.0178)$ & 0.0275 & $(0.0257)$ & 0.00575 & $(0.00566)$ \\
\hline Partnership & -0.103 & $(0.145)$ & -0.194 & $(0.199)$ & -0.0485 & $(0.0433)$ \\
\hline Single & 0.00875 & $(0.173)$ & -0.179 & $(0.237)$ & -0.0421 & $(0.0513)$ \\
\hline Other18 & -0.196 & $(0.334)$ & $-0.817^{* *}$ & $(0.412)$ & $-0.215^{* *}$ & $(0.0880)$ \\
\hline One_child & 0.250 & $(0.155)$ & 0.288 & $(0.215)$ & 0.0594 & $(0.0469)$ \\
\hline Two_children & -0.0517 & $(0.184)$ & -0.217 & $(0.247)$ & -0.0507 & $(0.0537)$ \\
\hline More_children & 0.0766 & $(0.242)$ & 0.295 & $(0.327)$ & 0.0708 & $(0.0716)$ \\
\hline German & 0.111 & $(0.210)$ & -0.0975 & $(0.299)$ & -0.00626 & $(0.0639)$ \\
\hline Years_since_final_degree & -0.00516 & $(0.0213)$ & -0.0308 & $(0.0303)$ & -0.00651 & $(0.00665)$ \\
\hline Master & 0.359 & $(0.269)$ & 0.281 & $(0.386)$ & 0.0572 & $(0.0815)$ \\
\hline Magister & 0.296 & $(0.205)$ & 0.400 & $(0.297)$ & 0.0891 & $(0.0644)$ \\
\hline Other23 & 0.217 & $(0.227)$ & -0.153 & $(0.305)$ & -0.00734 & $(0.0660)$ \\
\hline Years_since_graduation & -0.0151 & $(0.0223)$ & -0.00752 & $(0.0312)$ & -0.00220 & $(0.00686)$ \\
\hline PhD_in_Germany & 0.186 & $(0.252)$ & 0.00169 & $(0.366)$ & -0.0130 & $(0.0787)$ \\
\hline Business_Studies & $0.317^{* *}$ & $(0.153)$ & $0.442^{* *}$ & $(0.211)$ & $0.0904^{* *}$ & $(0.0450)$ \\
\hline Sociology_SocialScience & 0.199 & $(0.175)$ & 0.309 & $(0.238)$ & 0.0685 & $(0.0517)$ \\
\hline Other30 & $0.298^{*}$ & $(0.172)$ & 0.383 & $(0.236)$ & 0.0809 & $(0.0509)$ \\
\hline Assistant_Professor & 0.287 & $(0.228)$ & 0.133 & $(0.298)$ & 0.0254 & $(0.0648)$ \\
\hline Research_Assistant & -0.0753 & $(0.126)$ & -0.154 & $(0.170)$ & -0.0382 & $(0.0368)$ \\
\hline Status_Habilitation & $0.313^{* * *}$ & $(0.120)$ & $0.543^{* * *}$ & $(0.165)$ & $0.125^{* * *}$ & $(0.0346)$ \\
\hline Lecturer_Admin_Officer & 0.0698 & $(0.169)$ & 0.320 & $(0.243)$ & 0.0681 & $(0.0524)$ \\
\hline PhD_program & 0.212 & $(0.198)$ & 0.334 & $(0.272)$ & 0.0598 & $(0.0581)$ \\
\hline PhD_research_institution & 0.0983 & $(0.226)$ & 0.344 & $(0.307)$ & 0.0584 & $(0.0659)$ \\
\hline ExternalPhd_scholarship & $0.424^{* *}$ & $(0.197)$ & $1.069^{* * *}$ & $(0.312)$ & $0.244^{* * *}$ & $(0.0656)$ \\
\hline Other27 & 0.529 & $(0.352)$ & 0.435 & $(0.464)$ & 0.113 & $(0.101)$ \\
\hline PhD_current_university & 0.0209 & $(0.117)$ & 0.0349 & $(0.158)$ & 0.0124 & $(0.0344)$ \\
\hline National_conferences & -0.192 & $(0.150)$ & -0.151 & $(0.210)$ & -0.0274 & $(0.0454)$ \\
\hline International_conferences & $0.269^{*}$ & $(0.141)$ & $0.403^{* *}$ & $(0.190)$ & $0.0902^{* *}$ & $(0.0410)$ \\
\hline German_research_institute & 0.0349 & $(0.231)$ & 0.0193 & $(0.314)$ & 0.0112 & $(0.0675)$ \\
\hline Foreign_research_institute & 0.0463 & $(0.134)$ & 0.245 & $(0.187)$ & 0.0490 & $(0.0405)$ \\
\hline Referee_reports & -0.0272 & $(0.133)$ & -0.141 & $(0.180)$ & -0.0319 & $(0.0392)$ \\
\hline Publications & -0.0754 & $(0.121)$ & -0.0849 & $(0.166)$ & -0.0166 & $(0.0360)$ \\
\hline Third_party_funded_project & $0.272^{* *}$ & $(0.116)$ & 0.224 & $(0.159)$ & 0.0501 & $(0.0342)$ \\
\hline Prospects_outside_cat & $-0.284^{* * *}$ & $(0.0828)$ & $-0.381^{* * *}$ & $(0.113)$ & $-0.0857^{* * *}$ & $(0.0238)$ \\
\hline Prospects_outside_5y_cat & -0.0552 & $(0.0809)$ & -0.0252 & $(0.110)$ & -0.00543 & $(0.0238)$ \\
\hline Prospects_academia_cat & $0.644^{* * *}$ & $(0.0801)$ & $0.725^{* * *}$ & $(0.108)$ & $0.162^{* * *}$ & $(0.0204)$ \\
\hline Competition_academia_cat & 0.0573 & $(0.109)$ & 0.103 & $(0.149)$ & 0.0144 & $(0.0320)$ \\
\hline Networks_n & $-0.311^{* *}$ & $(0.122)$ & $-0.490^{* * *}$ & $(0.170)$ & $-0.0548^{*}$ & $(0.0294)$ \\
\hline Conditions_prospects_cat & $0.344^{* * *}$ & $(0.0689)$ & $0.377^{* * *}$ & $(0.0908)$ & $0.0793^{* * *}$ & $(0.0188)$ \\
\hline Networks_nI & 0.222 & $(0.203)$ & $0.700^{* *}$ & $(0.278)$ & & \\
\hline$N$ & 528 & & 528 & & 528 & \\
\hline
\end{tabular}

Marginal effects; Standard errors in parentheses

Values of the dependent variable (categorial): $1=$ a job outside of academic research $2=$ rather a job outside of academic research

$3=$ no preference, $4=$ rather an academic research job, $5=$ an academic research job Values of the dependent variable (binary):

$1=$ rather an academic research job + an academic research job , $0=$ other

(1): Ordered Probit, (2): Probit, (3): Marginal effects of Probit(2)

(d) for discrete change of dummy variable from 0 to 1

${ }^{*} p<0.1,{ }^{* *} p<0.05,{ }^{* * *} p<0.01$ 
Table 23: Average marginal effects for probit regressions of conditions and academic job

\begin{tabular}{|c|c|c|c|c|c|c|}
\hline \multirow{2}{*}{$\begin{array}{l}\text { Dependent } \\
\text { Variable } \\
\text { Female }\end{array}$} & \multicolumn{2}{|c|}{$\begin{array}{l}\text { Conditions improve } \\
\text { engagement in } \\
\text { academic career }^{a}\end{array}$} & \multicolumn{2}{|c|}{$\begin{array}{l}\text { Academic Research } \\
\text { Job in } 5 \text { years }^{b}\end{array}$} & \multicolumn{2}{|c|}{$\begin{array}{l}\text { Select Academic } \\
\text { Job at Present }\end{array}$} \\
\hline & 0.0161 & $(0.0456)$ & -0.00162 & $(0.0374)$ & 0.0212 & $(0.0366)$ \\
\hline Age & -0.00902 & $(0.00727)$ & 0.00354 & $(0.00521)$ & 0.00575 & $(0.00585)$ \\
\hline Partnership & 0.00378 & $(0.0551)$ & -0.0322 & $(0.0436)$ & -0.0485 & $(0.0447)$ \\
\hline Single & -0.0255 & $(0.0660)$ & 0.0373 & $(0.0540)$ & -0.0421 & $(0.0530)$ \\
\hline Other family status & -0.0730 & $(0.127)$ & 0.0198 & $(0.103)$ & $-0.215^{* *}$ & $(0.0910)$ \\
\hline One child & 0.0152 & $(0.0577)$ & 0.0393 & $(0.0468)$ & 0.0594 & $(0.0485)$ \\
\hline Two children & 0.108 & $(0.0691)$ & 0.00497 & $(0.0571)$ & -0.0507 & $(0.0555)$ \\
\hline More children & 0.127 & $(0.0939)$ & 0.125 & $(0.0788)$ & 0.0708 & $(0.0741)$ \\
\hline German & -0.0344 & $(0.0770)$ & 0.0386 & $(0.0692)$ & -0.00626 & $(0.0661)$ \\
\hline Years since final degree & 0.00717 & $(0.00890)$ & -0.00764 & $(0.00781)$ & -0.00651 & $(0.00687)$ \\
\hline Master & -0.0300 & $(0.0977)$ & 0.0740 & $(0.0847)$ & 0.0572 & $(0.0843)$ \\
\hline Magister & 0.0562 & $(0.0753)$ & $0.117^{*}$ & $(0.0622)$ & 0.0891 & $(0.0667)$ \\
\hline Other academic degree & -0.0222 & $(0.0815)$ & 0.0276 & $(0.0663)$ & -0.00734 & $(0.0682)$ \\
\hline Years since graduation & -0.00415 & $(0.00902)$ & 0.00856 & $(0.00768)$ & -0.00220 & $(0.00709)$ \\
\hline PhD in Germany & 0.114 & $(0.0958)$ & $-0.235^{* * *}$ & $(0.0888)$ & -0.0130 & $(0.0813)$ \\
\hline Business Studies & -0.0235 & $(0.0580)$ & $0.0840^{*}$ & $(0.0475)$ & $0.0904^{*}$ & $(0.0466)$ \\
\hline Sociology, Social Sciences & 0.0118 & $(0.0680)$ & 0.0803 & $(0.0537)$ & 0.0685 & $(0.0534)$ \\
\hline Other subject & -0.0235 & $(0.0650)$ & $0.0889^{*}$ & $(0.0532)$ & 0.0809 & $(0.0526)$ \\
\hline Assistant Professor & 0.114 & $(0.0829)$ & $0.150^{*}$ & $(0.0784)$ & 0.0254 & $(0.0670)$ \\
\hline Research Assistant & 0.0422 & $(0.0481)$ & $-0.0740^{* *}$ & $(0.0370)$ & -0.0382 & $(0.0380)$ \\
\hline Status Habilitation & 0.0240 & $(0.0455)$ & $0.0693^{* *}$ & $(0.0352)$ & $0.125^{* * *}$ & $(0.0359)$ \\
\hline Lecturer, Admin, Officer & 0.0422 & $(0.0637)$ & $0.105^{*}$ & $(0.0536)$ & 0.0681 & $(0.0542)$ \\
\hline PhD program & -0.0787 & $(0.0732)$ & -0.0730 & $(0.0585)$ & 0.0598 & $(0.0601)$ \\
\hline PhD research institution & 0.134 & $(0.0873)$ & -0.0634 & $(0.0703)$ & 0.0584 & $(0.0681)$ \\
\hline External PhD scholarship & -0.00909 & $(0.0743)$ & 0.0498 & $(0.0565)$ & $0.244^{* * *}$ & $(0.0679)$ \\
\hline Other PhD & -0.00598 & $(0.121)$ & -0.104 & $(0.108)$ & 0.113 & $(0.105)$ \\
\hline PhD current university & -0.00458 & $(0.0443)$ & 0.0324 & $(0.0360)$ & 0.0124 & $(0.0356)$ \\
\hline National conferences & 0.0387 & $(0.0578)$ & -0.0264 & $(0.0468)$ & -0.0274 & $(0.0470)$ \\
\hline International conferences & 0.0880 & $(0.0535)$ & $0.0698^{*}$ & $(0.0423)$ & $0.0902^{* *}$ & $(0.0425)$ \\
\hline German research institute & 0.0376 & $(0.0862)$ & -0.0297 & $(0.0688)$ & 0.0112 & $(0.0698)$ \\
\hline Foreign research institute & -0.0268 & $(0.0492)$ & -0.0309 & $(0.0400)$ & 0.0490 & $(0.0419)$ \\
\hline Referee reports & -0.0790 & $(0.0504)$ & 0.0340 & $(0.0405)$ & -0.0319 & $(0.0405)$ \\
\hline Publications & 0.00175 & $(0.0464)$ & -0.0304 & $(0.0375)$ & -0.0166 & $(0.0372)$ \\
\hline Third-party project & 0.00706 & $(0.0437)$ & 0.0407 & $(0.0356)$ & 0.0501 & $(0.0354)$ \\
\hline Prospects outside & -0.00210 & $(0.0320)$ & $-0.0884^{* * *}$ & $(0.0255)$ & $-0.0857^{* * *}$ & $(0.0246)$ \\
\hline Prospects outside $5 y$ & $0.0518^{*}$ & $(0.0299)$ & -0.00641 & $(0.0241)$ & -0.00543 & $(0.0246)$ \\
\hline Prospects academia & $0.185^{* * *}$ & $(0.0257)$ & $0.186^{* * *}$ & $(0.0194)$ & $0.162^{* * *}$ & $(0.0211)$ \\
\hline Competition academia & 0.0391 & $(0.0410)$ & -0.00911 & $(0.0324)$ & 0.0144 & $(0.0331)$ \\
\hline Networks & $-0.0854^{* *}$ & $(0.0385)$ & $-0.0518^{*}$ & $(0.0310)$ & $-0.0548^{*}$ & $(0.0305)$ \\
\hline Conditions prospects & & & $0.0926^{* * *}$ & $(0.0187)$ & $0.0793^{* * *}$ & $(0.0194)$ \\
\hline$N$ & 528 & & 498 & & 528 & \\
\hline
\end{tabular}

Marginal effects; Standard errors in parentheses

$a$ : Dependent Variable: conditions improve research incentives weakly or strongly positive.

$b$ : Dependent Variable: (rather) will have academic research job in 5 years.

$c$ : Dependent Variable: (rather) select academic research job at present.

(d) for discrete change of dummy variable from 0 to 1

${ }^{*} p<0.1,{ }^{* *} p<0.05,{ }^{* * *} p<0.01$ 
Table 24: Do you pursue applied research in order to improve your career prospects in jobs outside of academic research?

\begin{tabular}{|c|c|c|c|c|c|c|}
\hline \multirow[b]{2}{*}{ Applied_research } & \multicolumn{2}{|c|}{ Applied_research } & \multicolumn{2}{|c|}{ Applied_research } & \multicolumn{2}{|c|}{ Applied_research } \\
\hline & & & & & & \\
\hline Women & -0.0212 & $(0.120)$ & 0.00584 & $(0.118)$ & 0.0131 & $(0.112)$ \\
\hline Age & $0.0342^{*}$ & $(0.0202)$ & $0.0326^{*}$ & $(0.0195)$ & 0.0214 & $(0.0190)$ \\
\hline Partnership & $0.256^{*}$ & $(0.142)$ & 0.186 & $(0.140)$ & 0.174 & $(0.137)$ \\
\hline Single & -0.151 & $(0.169)$ & -0.187 & $(0.165)$ & -0.154 & $(0.161)$ \\
\hline Other18 & 0.597 & $(0.391)$ & 0.534 & $(0.386)$ & 0.302 & $(0.370)$ \\
\hline One_child & 0.160 & $(0.151)$ & 0.133 & $(0.148)$ & 0.143 & $(0.145)$ \\
\hline Two_children & -0.0524 & $(0.179)$ & -0.0297 & $(0.176)$ & -0.0190 & $(0.170)$ \\
\hline More_children & -0.265 & $(0.247)$ & -0.232 & $(0.242)$ & -0.153 & $(0.236)$ \\
\hline German & -0.00123 & $(0.203)$ & -0.150 & $(0.200)$ & -0.0202 & $(0.191)$ \\
\hline Years_since_final_degree & 0.0298 & $(0.0264)$ & 0.0183 & $(0.0260)$ & 0.00712 & $(0.0252)$ \\
\hline Master & -0.357 & $(0.250)$ & -0.202 & $(0.243)$ & -0.149 & $(0.236)$ \\
\hline Magister & 0.123 & $(0.202)$ & 0.273 & $(0.198)$ & 0.256 & $(0.188)$ \\
\hline Other23 & -0.186 & $(0.213)$ & -0.0587 & $(0.209)$ & 0.0137 & $(0.199)$ \\
\hline Years_since_graduation & $-0.0484^{*}$ & $(0.0261)$ & -0.0334 & $(0.0256)$ & -0.0121 & $(0.0245)$ \\
\hline PhD_in_Germany & -0.0323 & $(0.247)$ & -0.124 & $(0.243)$ & -0.222 & $(0.215)$ \\
\hline Business_Studies & 0.00561 & $(0.153)$ & -0.109 & $(0.147)$ & $-0.280^{* *}$ & $(0.134)$ \\
\hline Sociology_SocialScience & $0.326^{*}$ & $(0.178)$ & 0.261 & $(0.173)$ & 0.156 & $(0.164)$ \\
\hline Other30 & 0.136 & $(0.167)$ & 0.0106 & $(0.163)$ & -0.0224 & $(0.156)$ \\
\hline Assistant_Professor & 0.00151 & $(0.256)$ & 0.228 & $(0.248)$ & & \\
\hline Research_Assistant & 0.0147 & $(0.125)$ & 0.0674 & $(0.122)$ & & \\
\hline Status_Habilitation & -0.205 & $(0.139)$ & -0.0424 & $(0.133)$ & & \\
\hline Lecturer_Admin_Officer & 0.263 & $(0.166)$ & $0.300^{*}$ & $(0.163)$ & & \\
\hline PhD_program & 0.201 & $(0.192)$ & 0.0414 & $(0.187)$ & & \\
\hline PhD_research_institution & $0.531^{* *}$ & $(0.212)$ & $0.546^{* * *}$ & $(0.209)$ & & \\
\hline ExternalPhd_scholarship & 0.128 & $(0.196)$ & 0.221 & $(0.193)$ & & \\
\hline Other27 & 0.0681 & $(0.317)$ & 0.201 & $(0.313)$ & & \\
\hline PhD_current_university & -0.136 & $(0.116)$ & -0.0993 & $(0.114)$ & & \\
\hline National_conferences & $-0.356^{* *}$ & $(0.150)$ & -0.0916 & $(0.141)$ & & \\
\hline International_conferences & 0.225 & $(0.140)$ & 0.202 & $(0.137)$ & & \\
\hline German_research_institute & 0.0716 & $(0.228)$ & -0.00603 & $(0.222)$ & & \\
\hline Foreign_research_institute & -0.0325 & $(0.125)$ & -0.0292 & $(0.123)$ & & \\
\hline Referee_reports & 0.192 & $(0.131)$ & $0.246^{*}$ & $(0.128)$ & & \\
\hline Publications & 0.0556 & $(0.121)$ & 0.0294 & $(0.119)$ & & \\
\hline Third_party_funded_project & -0.127 & $(0.133)$ & -0.182 & $(0.131)$ & & \\
\hline Prospects_outside_cat & $-0.256^{* * *}$ & $(0.0844)$ & & & & \\
\hline Prospects_outside_5y_cat & 0.0364 & $(0.0797)$ & & & & \\
\hline Prospects_academia_cat & $0.183^{* *}$ & $(0.0797)$ & & & & \\
\hline Competition_academia_cat & 0.0918 & $(0.107)$ & & & & \\
\hline Networks_n & $-0.279^{* * *}$ & $(0.103)$ & & & & \\
\hline Conditions_prospects_cat & $0.171^{* *}$ & $(0.0682)$ & & & & \\
\hline Assistant_ProfessorI & 0.626 & $(0.384)$ & 0.607 & $(0.376)$ & & \\
\hline Status_HabilitationI & $0.647^{* * *}$ & $(0.247)$ & $0.471^{*}$ & $(0.243)$ & & \\
\hline Third_party_funded_projectI & -0.377 & $(0.231)$ & -0.357 & $(0.228)$ & & \\
\hline$N$ & 475 & & 476 & & 476 & \\
\hline
\end{tabular}

Standard errors in parentheses

Values of the dependent variable (categorial):

$1=$ that's right, this is one reason why I pursue only applied research

$2=$ that's right, this is one reason why I pursue applied research in addition to basic research

$3=$ that's wrong, I pursue applied research, but for other reasons $4=$ that's wrong, I pursue only basic research

${ }^{*} p<0.1,{ }^{* *} p<0.05,{ }^{* * *} p<0.01$ 
Table 25: Average marginal effects for probit regressions of assessments of competition and networks

\begin{tabular}{|c|c|c|c|c|}
\hline \multirow{2}{*}{$\begin{array}{l}\text { Dependent } \\
\text { variable }\end{array}$} & \multicolumn{2}{|c|}{$\begin{array}{l}\text { Competition in } \\
\text { academic field }^{a}\end{array}$} & \multicolumn{2}{|c|}{$\begin{array}{l}\text { Networks are more } \\
\text { important }^{b}\end{array}$} \\
\hline & -0.0388 & $(0.0412)$ & 0.0390 & $(0.0409)$ \\
\hline Age & 0.00256 & $(0.00637)$ & -0.000648 & $(0.00551)$ \\
\hline Partnership & 0.0126 & $(0.0478)$ & -0.0274 & $(0.0488)$ \\
\hline Single & $0.171^{* * *}$ & $(0.0599)$ & 0.0671 & $(0.0568)$ \\
\hline Other family status & $0.299^{*}$ & $(0.165)$ & 0.110 & $(0.108)$ \\
\hline One child & $0.0879^{*}$ & $(0.0518)$ & 0.0216 & $(0.0506)$ \\
\hline Two children & 0.0144 & $(0.0590)$ & -0.00942 & $(0.0616)$ \\
\hline More children & $0.181^{* *}$ & $(0.0855)$ & -0.0724 & $(0.0835)$ \\
\hline German & -0.120 & $(0.0770)$ & 0.0485 & $(0.0715)$ \\
\hline Years since final degree & -0.00789 & $(0.00804)$ & 0.0117 & $(0.00791)$ \\
\hline Master & -0.0515 & $(0.0893)$ & -0.0526 & $(0.0951)$ \\
\hline Magister & 0.111 & $(0.0692)$ & 0.0727 & $(0.0617)$ \\
\hline Other academic degree & $0.128^{*}$ & $(0.0761)$ & 0.0438 & $(0.0700)$ \\
\hline Years since graduation & -0.00155 & $(0.00806)$ & -0.0102 & $(0.00808)$ \\
\hline PhD in Germany & $-0.233^{* *}$ & $(0.106)$ & -0.00256 & $(0.0890)$ \\
\hline Business Studies & -0.0596 & $(0.0513)$ & 0.0274 & $(0.0535)$ \\
\hline Sociology, Social Sciences & -0.00323 & $(0.0605)$ & $0.106^{*}$ & $(0.0580)$ \\
\hline Other subject & -0.000216 & $(0.0593)$ & $0.131^{* *}$ & $(0.0572)$ \\
\hline Assistant Professor & $0.131^{*}$ & $(0.0763)$ & 0.106 & $(0.0724)$ \\
\hline Research Assistant & 0.0292 & $(0.0427)$ & -0.0669 & $(0.0420)$ \\
\hline Status Habilitation & $0.0860^{* *}$ & $(0.0408)$ & 0.0330 & $(0.0405)$ \\
\hline Lecturer, Admin, Officer & 0.0290 & $(0.0572)$ & 0.0255 & $(0.0567)$ \\
\hline PhD program & -0.0181 & $(0.0708)$ & -0.0134 & $(0.0662)$ \\
\hline $\mathrm{PhD}$ research institution & -0.0486 & $(0.0710)$ & -0.0462 & $(0.0755)$ \\
\hline External PhD scholarship & 0.0542 & $(0.0678)$ & 0.0231 & $(0.0607)$ \\
\hline Other PhD & -0.0548 & $(0.113)$ & -0.0683 & $(0.105)$ \\
\hline PhD current university & -0.0213 & $(0.0394)$ & $-0.0672^{*}$ & $(0.0385)$ \\
\hline National conferences & 0.0675 & $(0.0515)$ & -0.0576 & $(0.0486)$ \\
\hline International conferences & $-0.125^{* * *}$ & $(0.0476)$ & -0.0355 & $(0.0464)$ \\
\hline German research institute & -0.0298 & $(0.0776)$ & -0.0128 & $(0.0795)$ \\
\hline Foreign research institute & -0.00331 & $(0.0445)$ & 0.0326 & $(0.0442)$ \\
\hline Referee reports & $0.140^{* * *}$ & $(0.0442)$ & -0.0342 & $(0.0452)$ \\
\hline Publications & 0.0186 & $(0.0421)$ & 0.00635 & $(0.0403)$ \\
\hline Third-party project & -0.0403 & $(0.0400)$ & 0.0179 & $(0.0385)$ \\
\hline Prospects outside & -0.00301 & $(0.0282)$ & 0.0264 & $(0.0273)$ \\
\hline Prospects outside 5y & $-0.0436^{*}$ & $(0.0264)$ & -0.0127 & $(0.0274)$ \\
\hline Prospects academia & 0.0164 & $(0.0250)$ & $-0.100^{* * *}$ & $(0.0249)$ \\
\hline Networks & 0.00156 & $(0.0352)$ & & \\
\hline Competition academia & & & -0.0236 & $(0.0363)$ \\
\hline Conditions prospects & & & $-0.0694^{* * *}$ & $(0.0222)$ \\
\hline$N$ & 528 & & 528 & \\
\hline
\end{tabular}

Marginal effects; Standard errors in parentheses

$a$ : Dependent Variable: competition for academic career strong or very strong.

$b$ : Dependent Variable: networks are more important than academic excellence.

(d) for discrete change of dummy variable from 0 to 1

${ }^{*} p<0.1,{ }^{* *} p<0.05,{ }^{* * *} p<0.01$ 
Table 26: How strong is the competition for a successful academic career in your field?

(1)

Competition
$(2)$

Competition_bin Marginal effects

\begin{tabular}{|c|c|c|c|c|c|c|}
\hline \\
\hline \multicolumn{7}{|l|}{ Women } \\
\hline Age & 0.00161 & $(0.0160)$ & 0.00727 & $(0.0233)$ & 0.00274 & $(0.00614)$ \\
\hline Partnership & 0.0278 & $(0.134)$ & 0.0371 & $(0.179)$ & 0.0135 & $(0.0461)$ \\
\hline Single & $0.464^{* * *}$ & $(0.161)$ & $0.609^{* * *}$ & $(0.226)$ & $0.174^{* * *}$ & $(0.0579)$ \\
\hline Other18 & $0.733^{* *}$ & $(0.336)$ & $1.346^{* *}$ & $(0.649)$ & $0.308^{*}$ & $(0.161)$ \\
\hline One_child & 0.226 & $(0.170)$ & $0.662^{* * *}$ & $(0.247)$ & $0.0878^{*}$ & $(0.0501)$ \\
\hline Two_children & -0.0465 & $(0.169)$ & -0.00750 & $(0.219)$ & 0.0112 & $(0.0571)$ \\
\hline More_children & 0.267 & $(0.231)$ & $0.654^{* *}$ & $(0.321)$ & $0.175^{* *}$ & $(0.0829)$ \\
\hline German & -0.251 & $(0.193)$ & -0.372 & $(0.282)$ & -0.118 & $(0.0743)$ \\
\hline Years_since_final_degree & -0.0138 & $(0.0204)$ & -0.0161 & $(0.0289)$ & -0.00807 & $(0.00775)$ \\
\hline Master & -0.219 & $(0.241)$ & -0.163 & $(0.326)$ & -0.0475 & $(0.0863)$ \\
\hline Magister & 0.295 & $(0.186)$ & 0.416 & $(0.256)$ & 0.109 & $(0.0669)$ \\
\hline Other23 & $0.480^{* *}$ & $(0.203)$ & $0.553^{*}$ & $(0.286)$ & $0.130^{*}$ & $(0.0737)$ \\
\hline Years_since_graduation & -0.00903 & $(0.0215)$ & -0.0216 & $(0.0297)$ & -0.00139 & $(0.00778)$ \\
\hline PhD_in_Germany & $-0.412^{*}$ & $(0.240)$ & $-0.835^{* *}$ & $(0.392)$ & $-0.233^{* *}$ & $(0.102)$ \\
\hline Business_Studies & -0.103 & $(0.142)$ & -0.246 & $(0.190)$ & -0.0576 & $(0.0496)$ \\
\hline Sociology_SocialScience & 0.0215 & $(0.165)$ & -0.0744 & $(0.224)$ & -0.00256 & $(0.0584)$ \\
\hline Other30 & -0.113 & $(0.160)$ & -0.00885 & $(0.218)$ & 0.000557 & $(0.0573)$ \\
\hline Assistant_Professor & $0.367^{*}$ & $(0.205)$ & $0.470^{*}$ & $(0.283)$ & $0.130^{*}$ & $(0.0738)$ \\
\hline Research_Assistant & -0.00303 & $(0.118)$ & 0.0774 & $(0.158)$ & 0.0273 & $(0.0413)$ \\
\hline Status_Habilitation & $0.202^{*}$ & $(0.111)$ & $0.307^{* *}$ & $(0.153)$ & $0.0853^{* *}$ & $(0.0394)$ \\
\hline Lecturer_Admin_Officer & 0.140 & $(0.159)$ & 0.125 & $(0.211)$ & 0.0271 & $(0.0553)$ \\
\hline PhD_program & -0.0696 & $(0.184)$ & 0.0534 & $(0.261)$ & -0.0124 & $(0.0688)$ \\
\hline PhD_research_institution & -0.126 & $(0.203)$ & -0.245 & $(0.262)$ & -0.0526 & $(0.0688)$ \\
\hline ExternalPhd_scholarship & 0.0969 & $(0.180)$ & 0.207 & $(0.248)$ & 0.0520 & $(0.0653)$ \\
\hline Other27 & -0.268 & $(0.288)$ & -0.123 & $(0.425)$ & -0.0572 & $(0.109)$ \\
\hline PhD_current_university & -0.0480 & $(0.109)$ & -0.0933 & $(0.145)$ & -0.0210 & $(0.0381)$ \\
\hline National_conferences & 0.122 & $(0.140)$ & 0.249 & $(0.193)$ & 0.0668 & $(0.0497)$ \\
\hline International_conferences & $-0.341^{* *}$ & $(0.133)$ & $-0.505^{* * *}$ & $(0.180)$ & $-0.128^{* * *}$ & $(0.0460)$ \\
\hline German_research_institute & -0.196 & $(0.215)$ & -0.234 & $(0.285)$ & -0.0336 & $(0.0749)$ \\
\hline Foreign_research_institute & 0.0676 & $(0.122)$ & -0.0527 & $(0.166)$ & -0.00262 & $(0.0430)$ \\
\hline Referee_reports & $0.236^{*}$ & $(0.124)$ & $0.580^{* * *}$ & $(0.170)$ & $0.143^{* * *}$ & $(0.0428)$ \\
\hline Publications & 0.125 & $(0.115)$ & 0.100 & $(0.156)$ & 0.0202 & $(0.0407)$ \\
\hline Third_party_funded_project & -0.0786 & $(0.108)$ & -0.171 & $(0.149)$ & -0.0420 & $(0.0387)$ \\
\hline Prospects_outside_cat & 0.0325 & $(0.0775)$ & -0.0341 & $(0.105)$ & -0.00338 & $(0.0272)$ \\
\hline Prospects_outside_5y_cat & $-0.180^{* *}$ & $(0.0749)$ & $-0.205^{* *}$ & $(0.0986)$ & $-0.0467^{*}$ & $(0.0257)$ \\
\hline Prospects_academia_cat & -0.118 & $(0.0868)$ & -0.178 & $(0.116)$ & 0.00739 & $(0.0259)$ \\
\hline Networks_n & -0.0123 & $(0.0970)$ & -0.00317 & $(0.132)$ & 0.00493 & $(0.0342)$ \\
\hline Conditions_prospects_cat & 0.0148 & $(0.0654)$ & 0.0559 & $(0.0877)$ & 0.0217 & $(0.0228)$ \\
\hline One_childI & -0.264 & $(0.258)$ & $-0.961^{* * *}$ & $(0.357)$ & & \\
\hline Prospects_academia_catI & $0.438^{* * *}$ & $(0.128)$ & $0.600^{* * *}$ & $(0.171)$ & & \\
\hline$N$ & 528 & & 528 & & 528 & \\
\hline
\end{tabular}

Marginal effects; Standard errors in parentheses

Values of the dependent variable (categorial): $1=$ very weak

$2=$ weak, $3=$ average, $4=$ strong, $5=$ very strong

Values of the dependent variable (binary): $1=$ strong + very strong, $0=$ other

(1): Ordered Probit, (2): Probit, (3): Marginal effects of Probit(2)

(d) for discrete change of dummy variable from 0 to 1

${ }^{*} p<0.1,{ }^{* *} p<0.05,{ }^{* * *} p<0.01$ 
Table 27: What is the importance of networking (networks) to pursue an academic career?

\begin{tabular}{|c|c|c|c|c|c|c|}
\hline \multirow{2}{*}{ main } & \multicolumn{2}{|c|}{$\begin{array}{c}(1) \\
\text { Networks }\end{array}$} & \multicolumn{2}{|c|}{$\begin{array}{c}(2) \\
\text { Networks_bin1 }\end{array}$} & \multicolumn{2}{|c|}{$\begin{array}{c}(3) \\
\text { Marginal effects }\end{array}$} \\
\hline & & & & & & \\
\hline Women & 0.128 & $(0.124)$ & -0.245 & $(0.283)$ & -0.0166 & $(0.0217)$ \\
\hline Age & -0.000191 & $(0.0179)$ & -0.0182 & $(0.0424)$ & -0.00190 & $(0.00429)$ \\
\hline Partnership & -0.147 & $(0.151)$ & 0.230 & $(0.306)$ & 0.0236 & $(0.0311)$ \\
\hline Single & 0.0325 & $(0.179)$ & $0.590^{*}$ & $(0.341)$ & $0.0627^{*}$ & $(0.0346)$ \\
\hline Other18 & 0.0518 & $(0.353)$ & 0.858 & $(0.598)$ & 0.0854 & $(0.0597)$ \\
\hline One_child & -0.0332 & $(0.158)$ & 0.466 & $(0.319)$ & 0.0362 & $(0.0320)$ \\
\hline Two_children & -0.179 & $(0.191)$ & $0.603^{*}$ & $(0.358)$ & $0.0633^{*}$ & $(0.0361)$ \\
\hline More_children & -0.239 & $(0.260)$ & 0.472 & $(0.518)$ & 0.0375 & $(0.0531)$ \\
\hline German & 0.0803 & $(0.214)$ & 0.296 & $(0.428)$ & 0.0237 & $(0.0424)$ \\
\hline Years_since_final_degree & 0.0323 & $(0.0234)$ & -0.00976 & $(0.0504)$ & -0.000737 & $(0.00518)$ \\
\hline Master & -0.350 & $(0.268)$ & 0.640 & $(0.430)$ & 0.0674 & $(0.0434)$ \\
\hline Magister & 0.210 & $(0.205)$ & -0.0983 & $(0.459)$ & -0.00313 & $(0.0456)$ \\
\hline Other23 & 0.238 & $(0.223)$ & -0.626 & $(0.672)$ & -0.0646 & $(0.0679)$ \\
\hline Years_since_graduation & -0.0310 & $(0.0245)$ & 0.0389 & $(0.0535)$ & 0.00416 & $(0.00538)$ \\
\hline PhD_in_Germany & 0.0327 & $(0.265)$ & -0.348 & $(0.424)$ & -0.0281 & $(0.0430)$ \\
\hline Business_Studies & $0.417^{* * *}$ & $(0.159)$ & $-1.185^{* * *}$ & $(0.310)$ & $-0.123^{* * *}$ & $(0.0318)$ \\
\hline Sociology_SocialScience & $0.536^{* * *}$ & $(0.185)$ & $-1.129^{* * *}$ & $(0.394)$ & $-0.104^{* * *}$ & $(0.0379)$ \\
\hline Other30 & $0.510^{* * *}$ & $(0.178)$ & $-0.663^{* *}$ & $(0.299)$ & $-0.0641^{* *}$ & $(0.0304)$ \\
\hline Assistant_Professor & 0.0773 & $(0.225)$ & 0.572 & $(0.364)$ & 0.0583 & $(0.0376)$ \\
\hline Research_Assistant & -0.184 & $(0.132)$ & 0.210 & $(0.275)$ & 0.0188 & $(0.0281)$ \\
\hline Status_Habilitation & 0.147 & $(0.125)$ & -0.316 & $(0.251)$ & -0.0263 & $(0.0252)$ \\
\hline Lecturer_Admin_Officer & -0.215 & $(0.175)$ & $0.921^{* * *}$ & $(0.311)$ & $0.0950^{* * *}$ & $(0.0321)$ \\
\hline PhD_program & -0.0890 & $(0.203)$ & 0.0919 & $(0.344)$ & 0.0102 & $(0.0351)$ \\
\hline PhD_research_institution & -0.100 & $(0.227)$ & 0.131 & $(0.389)$ & 0.00684 & $(0.0395)$ \\
\hline ExternalPhd_scholarship & 0.116 & $(0.200)$ & -0.0676 & $(0.427)$ & -0.0196 & $(0.0445)$ \\
\hline Other27 & -0.0354 & $(0.320)$ & -0.510 & $(0.713)$ & -0.0504 & $(0.0721)$ \\
\hline PhD_current_university & -0.115 & $(0.121)$ & -0.00928 & $(0.246)$ & -0.00516 & $(0.0246)$ \\
\hline National_conferences & -0.221 & $(0.155)$ & 0.263 & $(0.304)$ & 0.0266 & $(0.0311)$ \\
\hline International_conferences & -0.00454 & $(0.148)$ & -0.409 & $(0.301)$ & -0.0424 & $(0.0304)$ \\
\hline German_research_institute & 0.150 & $(0.243)$ & -0.612 & $(0.562)$ & -0.0698 & $(0.0563)$ \\
\hline Foreign_research_institute & 0.0125 & $(0.135)$ & 0.201 & $(0.250)$ & 0.0251 & $(0.0253)$ \\
\hline Referee_reports & -0.0198 & $(0.159)$ & 0.222 & $(0.303)$ & -0.00716 & $(0.0269)$ \\
\hline Publications & -0.0821 & $(0.152)$ & -0.0768 & $(0.289)$ & 0.0140 & $(0.0255)$ \\
\hline Third_party_funded_project & 0.0398 & $(0.119)$ & 0.00825 & $(0.221)$ & 0.00407 & $(0.0225)$ \\
\hline Prospects_outside_cat & 0.0759 & $(0.0859)$ & 0.0615 & $(0.172)$ & 0.00225 & $(0.0174)$ \\
\hline Prospects_outside_5y_cat & -0.0933 & $(0.0837)$ & 0.208 & $(0.161)$ & 0.0219 & $(0.0164)$ \\
\hline Prospects_academia_cat & $-0.346^{* * *}$ & $(0.0976)$ & 0.152 & $(0.189)$ & 0.0279 & $(0.0172)$ \\
\hline Competition_academia_cat & -0.0255 & $(0.114)$ & -0.219 & $(0.208)$ & -0.0182 & $(0.0211)$ \\
\hline Conditions_prospects_cat & -0.138 & $(0.0845)$ & 0.221 & $(0.169)$ & 0.0124 & $(0.0148)$ \\
\hline$N$ & 528 & & 528 & & 528 & \\
\hline \multicolumn{7}{|c|}{$\begin{array}{l}\text { Marginal effects; Standard errors in parentheses } \\
\text { Values of the dependent variable (categorial): } \\
1=\text { Academic excellence is much more important than networks for a successful academic career } \\
2=\text { In addition to academic excellence, } \\
\text { networks are about equally important for a successful academic career } \\
3=\text { Networks are much more important than academic excellence for a successful academic career } \\
\text { Values of the dependent variable (binary1): } \\
1=\text { Academic excellence is much more important than networks for a successful academic career, } 0=\text { other } \\
\text { (d) for discrete change of dummy variable from } 0 \text { to } 1 \\
{ }^{*} p<0.1,{ }^{* *} p<0.05,{ }^{* * *} p<0.01\end{array}$} \\
\hline
\end{tabular}

